\title{
Batch Kd Measurements of Nuclides to Estimate Migration \\ Potential at the Proposed Waste Isolation Pilot Plant in New Mexico
}

October 7, 1977

Prepared for the

U.S. Department of Energy

under Contract EY-76-C-06-1830 
NOTICE

This report was prepared as an account of work sponsored by the United States Covernment. Neither the Unired States not the Desartment of Energy, nor any of their employees, nor any of their contractors. subitontractors, or their employees, makes any warranty. express or implied, or assumes any legal liability or responsibility for the accuracy, completeness or usefulness of any intormation, apparatus, product or process cisciosed, or represents that its use would not infringe privately owned rightz.

The views, opinions and conclusions contained in this report are those of the contractor and do not necessarily represent those of the United States Government or the United States Department of Energy.

\author{
PACIFIC NORTHWEST LABORATORY \\ operated by \\ BATTELLE \\ for the \\ UNITED STATES DEPARTMENT OF ENERGY \\ Under Contract EY-76-C-06-1830
}

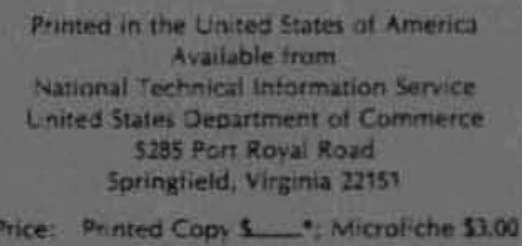

Price: Printed Copys : Microfiche 53.00

$\begin{array}{cc}\text { - Pases } & \text { Seiling Price } \\ 321-025 & \$ 4.50 \\ 726-050 & 55.00 \\ 051-075 & 55.50 \\ 975-100 & 56.00 \\ 101-125 & 56.50 \\ 125-150 & 57.00 \\ 151-175 & 57.75 \\ 772-200 & 56.50 \\ 201-225 & 52.75 \\ 225-250 & 59.00 \\ 231-275 & 510.00 \\ 276-300 & 510.25 \\ & \end{array}$




\section{5}

BATCH Kd MEASUREMENTS OF NUCLIDES TO ESTIMATE MIGRATION POTENTIAL AT THE PROPOSED WASTE ISOLATION PILOT PLANT IN NEW MEXICO

by

R. J. Serne

D. Rai

M. J. Mason

Battelle Pacific Northwest Labs

Water and Waste Management Section

and

M. A. Molecke

Sandia Laboratories

Nuclear Waste Technology Division

October 7, 1977

Battelle

Pacific Northwest Laboratories

Richland, Washington 99352 


\section{$\underline{\text { ABSTRACT }}$}

Laboratory measurements to determine the sorption distribution coefficients, $\mathrm{Kd}$, of radionuclides present in, and potentially leached from radioactive wastes, in contact with representative geologic media have been conducted. The nuclides studied include $\mathrm{Cs}, \mathrm{Sr}, \mathrm{Tc}, \mathrm{Ru}, \mathrm{Sb}, \mathrm{Ce}, \mathrm{Eu}$, $\mathrm{Pu}, \mathrm{Np}, \mathrm{Cm}, \mathrm{Am}, \mathrm{U}$, and $\mathrm{Pa}$. The crushed rock materials used were from the vicinity of the Waste Isolation Pilot Plant, a project to isolate radioactive wastes in a bedded salt facility, near Carlsbad, New Mexico. Solutions used consist of salt brine and groundwater, specific to the WIPP site, plus distilled water, for laboratory intercomparisons. The batch Kd data reported herein, plus data from sorption and migration measurements being conducted or planned elsewhere, will be used to evaluate the potential for radionuclide migration from the bedded salt WIPP facility. The data can be used for transport modeling and for safety assessment determinations. 


\section{CONTENTS}

\begin{tabular}{|c|c|c|c|c|c|c|c|c|c|c|c|c|c|c|c|c|c|}
\hline ABSTRACT & • & . & $\cdot$ & $\cdot$ & & $\cdot$ & & & . & $\cdot$ & $\cdot$ & - & & & & & \\
\hline IGURES & . & . . & . & $\cdot$ & & . & 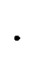 & 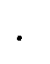 & • & - & . & . & & & & & i i \\
\hline INTRODUCT & ION & . & . & . & & . & & • & - & . & . & . & & & & & \\
\hline ATERIALS & AND & METHC & DS & . & • & . & $\cdot$ & $\cdot$ & $\cdot$ & $\cdot$ & - & $\cdot$ & & & & & \\
\hline GEOL & OGIC & MEDIf & $\mathrm{AH}$ & HAR & $r$ & ERI & $A$ & ION & & - & - & $\cdot$ & & & & & \\
\hline & Car & riers & Solu & iti & & Comp & & $i+i$ & ons & $\cdot$ & . & . & & & & & \\
\hline & Car & rier & Solu & ati & & Rad & & Is & tope & & $p$ i & & & & & & \\
\hline & Bat & $\mathrm{ch} \mathrm{Kd}$ & Exp & er & & ntal & & si & & $\cdot$ & $\cdot$ & . & & & & & \\
\hline & Cou & anting & Inf & or & the & ion & & $\bullet$ & . & . & . & . & & & & & \\
\hline RESUI & LTS & AND D. & $\mathrm{SSCl}$ & & {$[01$} & & . & & . & . & . & $\cdot$ & & & & & 0 \\
\hline DISC & USS I & ON. & - & $\cdot$ & • & . & & $\cdot$ & $\cdot$ & $\cdot$ & - & $\cdot$ & & & & & \\
\hline SUMM & ARY & $\cdot$ & . & $\cdot$ & $\cdot$ & . & . & $\cdot$ & . & $\cdot$ & . & . & & & & & \\
\hline RECOI & MMEN & NDATION & & $\cdot$ & . & . & $\cdot$ & $\cdot$ & . & $\cdot$ & . & $\cdot$ & & & & & 43 \\
\hline REFERENCE & & $\cdot$ & & • & - & . & • & $\cdot$ & . & $\cdot$ & . & $\cdot$ & & & & & 5 \\
\hline ACKNOWLEDC & GEME & NTS & . & . & - & . & . & $\cdot$ & . & $\cdot$ & . & $\cdot$ & & & & & \\
\hline PPENDIX & & 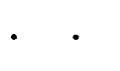 & & 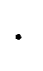 & . & . & & 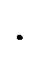 & . & . & • & . & & & & & \\
\hline PENDIX & & . & & . & & . & & & . & • & . & & & & & & \\
\hline
\end{tabular}




\section{FIGURES}

1. Mineral Identification . . . . . . . . . . . . . . 4

2. Counting Information .. . . . . . . . . . . . . 9

3. Estimated Porosity and Pore Sizes in Rock Materials . . . . 11

4. Surface Areas of Crushed Rock Samples . . . . . . . . . 10

5. Major Cation Concentrations of Synthetic Brines . . . . . . 12

6. Distilled Water Effluents $(\mathrm{mg} / \mathrm{l})$. . . . . . . . . . . 13

7. Wt\% Media Dissolved in Distilled Water (1g media/30 $\mathrm{mls}) . \quad . \quad 13$

8. Initial Activity of Batch Influents . . . . . . . . . . 14

9. Concentration of Radioelements in Batch Solutions vs.

Actual Leachate . . . . . . . . . . . . . 15

10. $\mathrm{pH}$ of Cold Washes . . . . . . . . . . . . . . 17

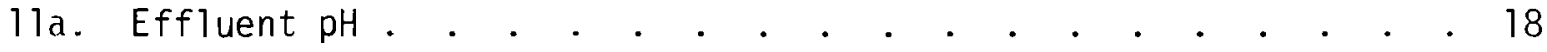

11b. Effluent $\mathrm{pH}$. . . . . . . . . . . . . . . . . . 19

11c. Effluent $\mathrm{pH}$. . . . . . . . . . . . . . . . . 20

12a. Fission Product $\mathrm{Kd}$ 's $(\mathrm{ml} / \mathrm{g})$. . . . . . . . . . . . 21

12b. Fission Product $\mathrm{Kd}^{\prime} \mathrm{s}(\mathrm{ml} / \mathrm{g})$. . . . . . . . . . . . 22

12c. Fission Product $\mathrm{Kd}$ 's $(\mathrm{ml} / \mathrm{g})$. . . . . . . . . . . . 23

12d. Fission Product $\mathrm{Kd}$ 's $(\mathrm{ml} / \mathrm{g})$. . . . . . . . . . . . . 24

13a. Actinide $\mathrm{Kd}^{\prime} \mathrm{s}(\mathrm{ml} / \mathrm{g})$. . . . . . . . . . . . . . . 25

13b. Actinide $\mathrm{Kd}^{\prime} \mathrm{s}(\mathrm{ml} / \mathrm{g})$. . . . . . . . . . . . . . . 26

14a. Fission Product $\mathrm{Kd}$ 's $\left(\mathrm{ml} / \mathrm{m}^{2}\right)$. . . . . . . . . . . . 27

14b. Fission Product $\mathrm{Kd} \mathrm{d}^{\mathrm{s}} \mathrm{s}\left(\mathrm{ml} / \mathrm{m}^{2}\right)$. . . . . . . . . . . . 28

14c. Fission Product $\mathrm{Kd} \mathrm{d}^{\mathrm{s}} \mathrm{s}\left(\mathrm{ml} / \mathrm{m}^{2}\right)$. . . . . . . . . . . . . 29

14d. Fission Product $\mathrm{Kd} \mathrm{d}^{\mathrm{s}} \mathrm{s}\left(\mathrm{ml} / \mathrm{m}^{2}\right)$. . . . . . . . . . . . 30 


\section{FIGURES (Continued)}

15a. Actinide $\mathrm{Kd} \mathrm{d}^{\prime} \mathrm{s}\left(\mathrm{ml} / \mathrm{m}^{2}\right)$. . . . . . . . . . . . . . . 31

15b. Actinide $\mathrm{Kd} \mathrm{d}^{\prime} \mathrm{s}\left(\mathrm{ml} / \mathrm{m}^{2}\right)$. . . . . . . . . . . . . . . . . 32

16. Range of pH Found in Effluents . . . . . . . . . . . 33

17. \% of Isotope Remaining in Blank Supernate . . . . . . . 40 


\section{BATCH Kd MEASUREMENTS OF NUCLIDES TO ESTIMATE MIGRATION POTENTIAL AT THE PROPOSED WASTE ISOLATION PILOT PLANT IN NEW MEXICO}

\section{INTRODUCTION}

In order to evaluate the potential for radionuclide migration from a radioactive waste isolation facility, and the consequences of such migration, many parameters must be evaluated. Important parameters include chemical and physical waste form, amount of nuclear waste present, solubility or leachability of the waste matrix, geologic stability and hydrologic regimes in the repository and adjacent horizons, potential for geochemical interactions (sorption-desorption) and transport time to the biosphere. The purpose of this study is to measure the geochemical interactions (sorption-desorption) of water borne nuclides in contact with various geologic materials. From knowledge of this waste-geologic media interaction and other mentioned parameters, preliminary evaluations of the potential for nuclide migration to the biosphere can be made.

A conimon parameter used to quantify the nuclide-geologic media sorption-desorption reactions is the distribution coefficient, Kd. The Kd for a nuclide is defined as the ratio of activity sorbed onto the solid (geologic) matrix divided by the activity remaining in the fluid phase:

$$
K d=\frac{\text { Activity on Solid }}{\text { Activity in Solution }}
$$

The $K d$ value has units of $\mathrm{ml} / \mathrm{g}$ or $\mathrm{ml} / \mathrm{m}^{2}$ depending upon whether one is assuming chemical interactions throughout a porous geologic structure or flow through cracks or fissures with chemical interactions occurring only on the exposed surfaces. The conversion between a $\mathrm{kd}$ for porous and fracture flow cases is theoretically possible with knowledge of the surface area to volume ratio of fissures present of the geologic material. 
Waste-rock interactions almost exclusively retard the movement of nuclides relative to the movement of the carrier water. In the specific case that the $K d$ is not a function of nuclide concentration (i.e., the sorption isotherms of the trace nuclide are linear) or time (equilibrium prevales at all points and all times), the retardation factor, $R$, is related to the kd by the following equations $(1,2)$ :

Porous Flow Case

$$
\begin{aligned}
R=\frac{V \text { Fluid }}{V \text { Nuclide }}= & 1+\frac{\mathrm{pb}}{\theta} \mathrm{Kd} \\
\text { Where } & \begin{aligned}
\mathrm{R} & =\text { retardation factor } \\
V \text { Nuclide } & =\text { velocity of nuclide } \\
V \text { Fluid } & =\text { velocity of carrier solution } \\
P_{b} & =\text { bulk density of porous media }\left(\mathrm{g} / \mathrm{cm}^{3}\right) \\
\theta & =\text { fractional porosity of porous media } \\
K d & =\text { distribution coefficient }\left(\mathrm{ml} / \mathrm{g}-\mathrm{cm}^{3} / \mathrm{g}\right)
\end{aligned}
\end{aligned}
$$

Fracture Flow Case

$$
R=\frac{V \text { Water }}{V \text { Nuclide }}=1+\frac{S A}{L V} K d
$$

where $\quad S A=$ surface area of fracture $\left(\mathrm{m}^{2}\right)$

$$
\begin{aligned}
& L v=\text { volume of liquid in fracture }(\mathrm{ml}) \\
& K d=\text { distribution coefficient }\left(\mathrm{ml} / \mathrm{m}^{2}\right)
\end{aligned}
$$

The mathematical treatment of the coupled water transport-nuclide sorption has taken two paths. The simpler approach assumes that the porosity remains constant, the $\mathrm{kd}$ remains a constant and the water velocity remains constant. With these further restrictions an exact or analytical solution is possible $(1,2)$. The other approach uses numerical techniques to approximate the solution of the coupled water-sorption equations without requiring the additional assumptions $(3,4)$.

Therefore, if one can evaluate the hydrologic regimes of interest, the migration of nuclides can be estimated from measurement of $K d^{\prime} \mathrm{s}$ and calculation of the appropriate retardation factor. 
The staff at Battelle Pacific Northwest Lab was presented a subcontract from Sandia Laboratories to make preliminary Kd measurements on long lived actinide and fission product nuclides in ground waters contacting representative rock types from a potential radioacitve waste disposal facility located near Carlsbad, New Mexico. Sandia Laboratories is managing this program for ERDA. It is entitled the Waste Isolation Pilot Plant (WIPP). The objective of this program is to evaluate the scientific and engineering feasibility of operating a facility for the long-term isolation of radioactive wastes in a deep geologic salt bed. Assuming a favorable thorough evaluation, this "pilot plant" facility will be converted to a terminal repository, primarily for ERDA defense related wastes. The batch Kd results reported herein will be used in part to evaluate the potential for radionuclide migration from the WIPP facility, for transport modeling, and for safety assessment determinations. 
MATERIALS AND METHODS

\section{GEOLOGIC MEDIA CHARACTERIZATION}

Seven core samples of salt and rocks, including samples from geologic horizons above and below the proposed repository were obtained. The major crystalline constituents were determined by $x$-ray diffraction techniques. Results are given in Table 1.

\section{Table 1. Mineral Identification}

\begin{tabular}{ll}
\multicolumn{1}{c}{ Sample } & \multicolumn{1}{c}{ Major Minerals } \\
Culebra-853' & $\begin{array}{l}\text { Dolomite }(\mathrm{Ca}, \mathrm{Mg} \text { carbonate); very minor } \\
\text { quartz }\left(\mathrm{SiO}_{2}\right) \text { and calcite }\left(\mathrm{CaCO}_{3}\right)\end{array}$ \\
Magenta-734' & $\begin{array}{l}\text { Dolomite }(\mathrm{Ca}, \mathrm{Mg} \text { carbonate); minor quartz } \\
\text { and gypsum }\left(\mathrm{CaSO}_{4} \cdot 2 \mathrm{H}_{2} \mathrm{O}\right)\end{array}$ \\
\#1 Cherry Canyon & Limestone $\left(\mathrm{CaCO}_{3}\right)$ \\
\#2 Cherry Canyon & $\begin{array}{l}\text { Arkosic sandstone (feldspar bearing) with } \\
\text { calcic cement }\end{array}$ \\
\#3 Cherry Canyon & $\begin{array}{l}\text { Arkosic sandstone (feldspar bearing) with } \\
\text { siliceous cement }\end{array}$ \\
Salt Core-2726' & $\begin{array}{l}\text { NaCl ( 99\%), less than } 1 \% \text { by weight of the } \\
\text { clays montmorillonite, illite, chlorite, } \\
\text { possibly some magnesite and gypsum }\end{array}$ \\
Salt Core-2150' & $\begin{array}{l}\text { NaCl ( } 90+\%), \text { montmorillonite, chlorite } \\
\text { kaolinite, } i 11 \text { ite, magnesite }\end{array}$
\end{tabular}

The five nonsalt samples were also studied using optical microscopy techniques from which pore sizes and configurations can be determined. A rough estimate of porosity can also be performed by simple area calculations. The porosity and average pore sizes were determined by measurement of black regions of the optical photographs which represent the void spaces. Optical photographs of the cores are shown in Figures $A-1$ to $A-24$ in Appendix $A$. 
The Culebra and Magenta samples are part of the Salado formation, a now dry but potential aquifer region overlying (by many hundreds of feet) the salt bed where wastes are to be deposited. Samples \#1, \#2, and \#3 Cherry Canyon represent a potential aquifer region over a thousand feet below the waste storage horizon. These samples were obtained from outcroppings, not from actual corings at the WIPP site. The salt core at $2726^{\prime}$ down (from the surface) is from the WIPP horizon where intermediate-level wastes and high-level waste experiments will be placed. The salt core at $2150^{\prime}$ down is from the WIPP horizon where low-level transuranic waste will be stored.

Portions of the core samples of the five nonsalt rocks were crushed in a ball mill to provide material for batch Kd determinations. The size fraction 44-149um was separated and used for subsequent experimentation.

Surface areas of the crushed rocks, within the particle range 44-149um, were determined by the ethylene glycol method. (5)

Carrier Solution Compositions

Per initial Sandia suggestions, August 11, 1976 (see Appendix B), two salt brines were prepared. These brines were to simulate realistic geologic solutions which could potentially intrude into the waste repository, leach the wastes contained therein, and then serve as a transport medium for radionuclides to escape from the repository. Brine "XA" is representative of concentrated brines originating in the overlying Salado region, and which may intrude into the repository from above. Brine "XB" is a hypothetical Castile region brine which might intrude upon the repository from below. The chemical compositions for brines "XA" and "XB" are in Appendix $B$. These compositions had been based on commercial laboratory analyses of similar brines found near the WIPP site. It was later found, however, that these analyses, obtained from a commercial laboratory, were in error, particularily for the sodium ion.

The Brine "XA" recipe appeared to be supersaturated and would not totally dissolve. Several days of heating and stirring did not help. The

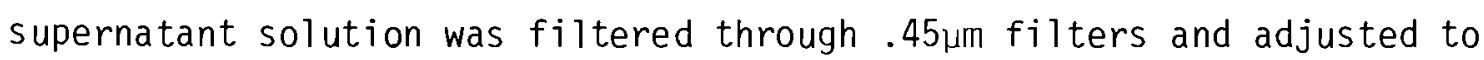


pH 6.5. (Major cations were determined so that the actual concentrations could be determined.) The Brine "XB" recipe would not support a 50 ppm $\mathrm{Fe}^{+3}$ and also necessitated filtration through $.45 \mu \mathrm{m}$ filters before final pH adjustment.

For the first series of experiments, distilled water was used as a carrier solution, primarily for laboratory expediency and for interlaboratory comparisons of results. Upon contact with the rocks a finite amount of material was expected to dissolve into the distilled water. As the $\mathrm{Kd}$ for each nuclide is dependent on the solution composition after contact with the rock, the total amount of rock material which could dissolve in the distilled water was determined by contacting 1 gram dry weight of crushed rock with $30 \mathrm{mls}$ of distilled water. This solid to solution ratio was used in all batch Kd experiments. The equilibration process was performed for 47 days. The concentration of major cations found in the effluents and percentage weight loss in the rocks were calculated from atomic absorption and weighing procedures, respectively.

The brine solutions "XA" and "XB" were modified midway through this experimental study by mutual agreement. This eliminated the error in the initial analyses that these solutions were based on, and simplified preparation of the carrier solutions. The new solutions, brine "A", brine "B", and groundwater "C" are described (ionic composition and formulations for preparation) in the 0ctober 8, 1976 Sandia letter found in Appendix B. New brine "B" is the resultant solution occuring when water dissolves rocksalt originating in the ILW-HLW horizon of the WIPP facility. It was originally prepared (at Sandia Laboratories) by preparing a saturated mixture of salt core ( $299 \%$ pure $\mathrm{NaCl})$ and water, heating, stirring, then filtering the solution and analyzing. Brine "B" prepared this way is not $100 \%$ theoretically saturated. The new brine "A" is again a Salado region brine. Solution " $C$ " is representative of the groundwater that livestock drink in the vicinity of the WIPP site. After lab makeup of solutions "A", "B", and " $C$ ", they were allowed to equilibrate for several days after $\mathrm{pH}$ adjustment and filtered through $0.45 \mu \mathrm{m}$ filters. 
Carrier Solution Radioisotope Doping

Subsamples of the Brines "XA" and "XB" and distilled water were spiked with ${ }^{152} \mathrm{Eu},{ }^{144} \mathrm{Ce},{ }^{125} \mathrm{Sb},{ }^{85} \mathrm{Sr},{ }^{137} \mathrm{Cs}$, and ${ }^{106} \mathrm{Ru}$. These represent the most common fission products found in radioactive wastes. The europium and cerium can also be used to estimate the behavior of other rare earths isotopes and some actinides present in the wastes.

Subsamples of Brines "A" and "B" and groundwater " $C$ " were spiked with

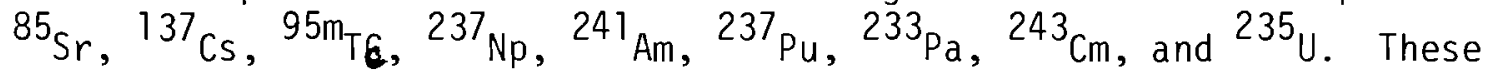
isotopes represent the most important actinide and long lived fission products found in nuclear wastes.

After readjustment of $\mathrm{pH}$ and several days mixing the solutions were filtered through $0.45 \mu \mathrm{m}$ membranes to remove any precipitates.

Batch Kd Experimental Design (6)

One gram samples of the crushed rocks, 44-149um were placed in $50 \mathrm{ml}$ polycarbonate centrifuge tubes. The samples were contacted with two-30 ml cold washes of either brine, groundwater or distilled water. Each wash step was 24 hours in duration. The samples were centrifuged at $5000 \mathrm{rpm}$ for 20 minutes and the washes decanted. Effluent $\mathrm{pH}^{\prime} \mathrm{s}$ were recorded and the next influent adjusted in the direction to cause the equilibrium effluent $\mathrm{pH}$ to approach the appropriate $\mathrm{pH}$ (6.5 for brines, 7.5 for groundwater " $\mathrm{C}$ "). This procedure for $\mathrm{pH}$ adjustment after rock contact is representative of the situation where large quantities of carrier solution, leachant, or transport fluid are present compared to the available rock material. (Data obtained without pH adjustment after rock-solution contact will be reported by R. G. Dosch, Sandia Laboratories, at a later date.) It was not possible to force the $\mathrm{pH}$ of the distilled water effluents to $\mathrm{pH} 6.5$ as the rocks contained carbonates.

A third solution-rock contact utilizing radionuclide spiked carrier solution was used. At periodic intervals the spiked solutions were removed from the shaker and centrifuged. Supernatant solutions were counted utilizing gamma ray spectroscopy ( $\mathrm{L} i$ drifted Ge detector) or x-ray-gamma ray 
spectroscopy (intrinsic Ge detector). Influent solutions were placed in identical polyethylene test tubes without crushed rock as blank tests to account for any container sorption. Effluent pH's were also monitored at each counting period. After counting the solution was placed back in contact with the crushed rocks and agitation continued.

Kd values for the isotopes were calculated with units of $\mathrm{ml} / \mathrm{g}$ and $\mathrm{m} 1 / \mathrm{m}^{2}$ surface area. The average value of triplicates and standard deviation are reported after several equilibration periods to evaluate the time dependence of $\mathrm{Kd}$.

The Kd was calculated by observing the difference in count rates between a blank tube (without geologic media) and the effluents from each slurry tube upon centrifugation and supernatant solution removal. The following equations were used:

Porous Flow Case

$$
\begin{gathered}
K d(\mathrm{ml} / \mathrm{g})=\frac{r(B \text { lank Count Rate) }-(\text { Effluent Count Rate })}{\text { (Effluent Count Rate) }} \times \\
\frac{\text { Total mls of Liquid }}{\mathrm{g} \text { of rock }} \\
r=\frac{\text { Spike Solution Volume }}{\text { Total mls of Liquid }} \\
\text { Total mls of Liquid = Spike Solution Volume + Excess Cold } \\
\text { Solution not Removed Upon Centrifugation }
\end{gathered}
$$

Fracture Flow Case

$$
\begin{aligned}
\mathrm{Kd}\left(\mathrm{ml} / \mathrm{m}^{2}\right)= & \frac{r(\text { Blank Count Rate })-(\text { Effluent Count Rate })}{\text { Effluent Count Rate }} \times \\
& \frac{\text { Total } \mathrm{mls} \text { of Liquid }}{\text { Surface Area of Rock in } \mathrm{m}^{2}}
\end{aligned}
$$

Counting Information

The following isotopes were mixed together and corrections made for the compton scattering contributions to the energy levels of each isotope. The mixtures and counting method utilized are shown in Table 2. 
Table 2. Counting Information

$\begin{array}{lll}\text { Mixtures of Isotopes } & \\ { }^{152} \mathrm{Eu}-{ }^{125} \mathrm{Sb}-{ }^{106} \mathrm{Ru} & \mathrm{Ge}(\mathrm{Li}) \text { Detector Gamma Spectroscopy } \\ { }^{144} \mathrm{Ce}-{ }^{85} \mathrm{Sr}-{ }^{137} \mathrm{Cs} & \mathrm{Ge}(\mathrm{Li}) \text { Detector Gamma Spectroscopy } \\ { }^{95 \mathrm{~m}} \mathrm{Tc}-{ }^{85} \mathrm{Sr}-{ }^{137} \mathrm{Cs} & \mathrm{Ge}(\mathrm{Li}) \text { Detector Gamma Spectroscopy } \\ 235 \mathrm{U}-{ }^{243} \mathrm{Cm} & \mathrm{Ge}(\mathrm{Li}) \text { Detector Gamma Spectroscopy } \\ 237 \mathrm{Pu} & \mathrm{Ge}(\mathrm{Li}) \text { Detector Gamma Spectroscopy } \\ { }^{237} \mathrm{~Np}-{ }^{241} \mathrm{Am}-{ }^{233} \mathrm{~Pa} & \mathrm{Ge} \text { Intrinsic Diode X and Gamma }\end{array}$

\begin{tabular}{|c|c|}
\hline & $\begin{array}{c}\begin{array}{c}\text { Energy Level Windows } \\
(\mathrm{kev})\end{array} \\
\end{array}$ \\
\hline $152 \mathrm{Eu}$ & $119 . \quad-125$. \\
\hline${ }^{5} \mathrm{Sb}$ & $425 . \quad-431$ \\
\hline $1066_{\mathrm{Ru}}$ & 509. $-515 .\left({ }^{106} R h\right)$ \\
\hline${ }^{4} \mathrm{Ce}$ & $131 . \quad-137$ \\
\hline${ }^{35} \mathrm{Sr}$ & $511 .-517$. \\
\hline${ }^{7} \mathrm{Cs}$ & $659 . \quad-665$ \\
\hline${ }^{235} U$ & $183 .-189$ \\
\hline${ }^{243} \mathrm{Cm}$ & $275 . \quad-281$ \\
\hline${ }^{237} \mathrm{Pu}$ & 94. -104. \\
\hline${ }^{237} \mathrm{~Np}$ & $28.8-30.0$ \\
\hline${ }^{241} \mathrm{Am}$ & $58.9-60.1$ \\
\hline${ }^{233} \mathrm{~Pa}$ & $97.8-99.0$ \\
\hline
\end{tabular}




\section{RESULTS AND DISCUSSIONS}

The porosity and average pore size of the core materials available were determined by visual measurement of the black regions of the optical photographs which represent the void spaces in the rocks. The results are shown in Table 3 .

The Magneta and Culebra samples showed respectively two and three homogeneous circular pore sizes. The Magenta pore sizes were 13-16um and

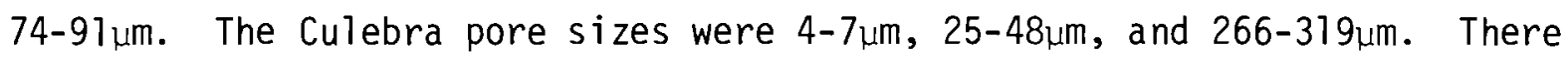
appears to be a slightly larger transverse (perpendicular to core) porosity compared to longitudinal (parallel to core) porosity. The pore shapes in Cherry Canyon \#2 and \#3 are highly irregular with estimated radii of up to 40-70um. Cherry Canyon \#1 is very closely packed with little optically determinable porosity. The rock materials, excepting Cherry Canyon \#1, show a bulk porosity of $10-20 \%$ by this optical methodology and would thus be expected to yield some porous water flow even if the horizons are devoid of cracks and fractures.

Optical photographs of the cores are shown in Figures 1-24 in Appendix $A$.

Surface areas of the crushed rocks, 44-149um, were determined by the ethylene glycol method so the batch Kd measurements can be calculated on weight and surface area bases. The surface areas and size range of particles used in the batch $\mathrm{Kd}$ experiments are shown in Table 4.

Table 4. Surface Areas of Crushed Rock Samples

\begin{tabular}{|c|c|c|}
\hline & $(\mu m)$ & $\mathrm{m}^{2} / \mathrm{g}$ \\
\hline Magenta & $44-149$ & 8.1 \\
\hline Culebra & $44-149$ & 7.1 \\
\hline Cherry Canyon \#1 & $88-149$ & 1.3 \\
\hline Cherry Canyon \#2 & $88-149$ & 5.2 \\
\hline Cherry Canyon \#3 & $44-149$ & 11.0 \\
\hline Reference Bentonite & & $736 \pm 16$ \\
\hline
\end{tabular}


Table 3. Estimated Porosity and Pore Sizes in Rock Materials

\begin{tabular}{|c|c|c|c|c|c|c|}
\hline \multicolumn{3}{|c|}{ Rock } & $\begin{array}{c}\text { Photo } \\
\text { Magnification }\end{array}$ & $\begin{array}{l}\text { Negative } \\
\text { File No. }\end{array}$ & $\begin{array}{c}\text { Determined } \\
\text { Porosity } \\
\% \text { Volume }\end{array}$ & $\begin{array}{c}\text { Pore Size } \\
\text { (radius in } \mu \mathrm{m})\end{array}$ \\
\hline \multicolumn{3}{|c|}{ Magenta-L } & $8 x$ & $4 L 585 \mathrm{~A}$ & 5.5 & 79 \\
\hline \multicolumn{3}{|c|}{$-T$} & $8 x$ & $4 L 586 \mathrm{~A}$ & 10. & 77 \\
\hline \multirow{2}{*}{\multicolumn{3}{|c|}{$-L$}} & $50 x$ & $4 L 585 B$ & 6.0 & 74 \\
\hline & & & & & 7.0 & 16 \\
\hline \multirow{2}{*}{\multicolumn{3}{|c|}{$-T$}} & $50 x$ & $4 L 586 B$ & 9.6 & 91 \\
\hline & & & & & 4.8 & 13 \\
\hline \multirow{2}{*}{\multicolumn{3}{|c|}{ Culebra-L }} & $8 x$ & $4 L 587 \mathrm{~A}$ & 4.0 & 266 \\
\hline & & & & & 2.0 & 31 \\
\hline \multirow{2}{*}{\multicolumn{3}{|c|}{$-T$}} & $8 x$ & $4 L 588 \mathrm{~A}$ & 3.7 & 319 \\
\hline & & & & & 4.5 & 45 \\
\hline \multirow{2}{*}{\multicolumn{3}{|c|}{$-L$}} & $50 x$ & $4 L 587 B$ & 4.0 & 27 \\
\hline & & & & & 12.0 & 4 \\
\hline \multirow{3}{*}{\multicolumn{3}{|c|}{$-T$}} & $50 x$ & $4 L 588 B$ & 1.0 & 48 \\
\hline & & & & & 2.0 & 25 \\
\hline & & & & & 4.0 & 7 \\
\hline Cherry & Canyon & $\# 1-L$ & $250 x$ & $\begin{array}{l}4 \mathrm{~L} 1164 \\
\mathrm{~A} \text { to } \mathrm{D}\end{array}$ & Very Low & Very Sma 11 \\
\hline Cherry & Canyon & $\# 1-T$ & & $\begin{array}{l}4 \mathrm{~L} 1165 \\
\text { A to } D\end{array}$ & Very Low & Very Sma 11 \\
\hline Cherry & Canyon & $\# 2-L$ & $200 x$ & $4 L 1166 \mathrm{E}$ & 18 & $\begin{array}{l}\text { Irregular Up } \\
\text { to } 75 \mathrm{\mu m}\end{array}$ \\
\hline Cherry & Canyon & $\# 2-T$ & & $4 L 1167 \mathrm{~F}$ & 20 & $\begin{array}{l}\text { Irregular Up } \\
\text { to } 40 \mu \mathrm{m}\end{array}$ \\
\hline Cherry & Canyon & $\# 3-L$ & $200 x$ & $4 L 1168 \mathrm{G}$ & 16 & $\begin{array}{l}\text { Irregular Up } \\
\text { to } 40 \mathrm{\mu m}\end{array}$ \\
\hline Cherry & Canyon & $\# 3-T$ & & $4 L 1169 \mathrm{G}$ & 17 & $\begin{array}{l}\text { Irregular Up } \\
\text { to } 35 \mu m\end{array}$ \\
\hline
\end{tabular}


Compared to clay material such as bentonite, the five rocks from neighboring horizons adjacent to the WIPP facility have low surface areas per mass of material. If sorption is proportional to surface area, the rocks under study would offer less capacity for sorption. Specutatively, this fact may not be important since the mass of nuclides which might be mobilized would be small compared to available exchange sites. Selectivity for sorption rather than capacity is probably a much more important parameter in predicting nuclide migration. It might also be possible to engineer a barrier of high sorptive capacity material such as clay to surround the repository and aid in nuclide retention in the event of solution contact. This possibility, termed "gettering", is being investigated at Sandia Laboratories with E. J. Nowak as a principle investigator.

Table 5 shows the major cation concentrations measured in the synthetic brines "XA" and "XB" versus the expected concentrations determined from their specified formulation. All analyses were performed with flame atomic adsorption.

Table 5. Major Cation Concentrations of Synthetic Brines

\begin{tabular}{|c|c|c|c|c|}
\hline & \multicolumn{4}{|c|}{ Salt Brine "XA" } \\
\hline & $\begin{array}{l}\mathrm{Ca} \\
\%\end{array}$ & $\begin{array}{l}\mathrm{Mg} \\
\%\end{array}$ & $\begin{array}{l}\mathrm{Na} \\
\% \\
\end{array}$ & $\begin{array}{l}\mathrm{K} \\
\% \\
\end{array}$ \\
\hline Measured & 0.11 & 3.71 & 4.07 & 5.02 \\
\hline \multirow[t]{3}{*}{ Calculated } & 0.13 & 3.80 & 5.70 & 5.20 \\
\hline & \multicolumn{2}{|c|}{ Salt Brine } & "XB" & \\
\hline & $\begin{array}{c}\mathrm{Ca} \\
\mathrm{mg} / 1 \\
\end{array}$ & $\begin{array}{c}\mathrm{Mg} \\
\mathrm{mg} / 1 \\
\end{array}$ & $\begin{array}{l}\mathrm{Na} \\
\% \\
\end{array}$ & $\begin{array}{r}\mathrm{K} \\
\mathrm{mg} / 1 \\
\end{array}$ \\
\hline Measured & 912 & 945 & 8.3 & 4870 \\
\hline Calculated & 800 & 1000 & 11.5 & 5000 \\
\hline
\end{tabular}

Comparison of measured values versus calculated values (based on the specified formulations) for the influents show acceptable agreement for $\mathrm{Mg}$ and $K$ and fair agreement for $\mathrm{Ca}$. In both instances the measured sodium concentrations are about 30\% 10w. As Brine "XB" had an insignificant 
insoluble portion after makeup, it is doubtful that the low sodium observed in Brine "XA" or "XB" was due to incomplete dissolution. It is most likely due to the error in the origional commercial brine analyses mentioned earlier or the salt brine matrix may be causing a negative interference on the sodium analysis. The amount of salt left undissolved in the salt brine "XA" makeup was not quantified but was estimated to be $<10 \%$.

The amount of rock material which dissolved on contact with distilled water is shown in Tables 6 and 7.

Table 6. Distilled Water Effluents (mg/l)

\begin{tabular}{|c|c|c|c|c|}
\hline Media & $\mathrm{Ca}$ & $\mathrm{Mg}$ & $\mathrm{Na}$ & K \\
\hline & 12 & 7. & 2. & 0.9 \\
\hline Culeb & 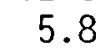 & 4 & 2. & 0.4 \\
\hline $\mathrm{Ca}$ & 16. & 0 & & 0.1 \\
\hline Cherry Canyon \#2 & 9. & 1. & 2.4 & 0.3 \\
\hline Cherry Canyon \#3 & 9.4 & 1.8 & 2.3 & 0.3 \\
\hline
\end{tabular}

Table 7. Wt\% Media Dissolved in Distilled Water ( $\mathrm{g}$ media/30 $\mathrm{mls}$ )

\begin{tabular}{ll}
\multicolumn{1}{c}{ Media } & $\%$ \\
\cline { 1 - 1 } Magenta & 4 \\
Culebra & 3 \\
Cherry Canyon \#1 & 1 \\
Cherry Canyon \#2 & 1 \\
Cherry Canyon \#3 & 2
\end{tabular}

The distilled water samples dissolved only small portions of the rock materials. The Cherry Canyon \#1 sample (limestone) released about $.495 \mathrm{mg}$ $\mathrm{Ca} / \mathrm{g}$ of crushed rock (16.5 ppm Ca in $30 \mathrm{mls}$ of solution). The Magenta sample (dolomite) released $.360 \mathrm{mg} \mathrm{Ca/g}$ whereas the Culebra sample (also a dolomite) released the least Ca. The two dolomites, Magenta and Culebra released substantially more magnesium than the other rock types as might be expected. Small portions of alkali metals, $\mathrm{Na}$ and $\mathrm{K}$, were released by all the rocks. The equilibrium solutions formed by distilled water in contact with the rocks under study are similar to a low ionic strength groundwater 
but are still over 25 times more dilute than the groundwater (solution "C") pumped from an aquifer in the Rustler formation. Thus if cationic competition is an important mechanism in the exchange or sorption of trace nuclides, the Kd results using distilled water may be biased high compared to expected results in typical non-salt brine groundwaters in the region. The utilization of distilled water as a carrier water for any Kd determinations is probably a poor choice as the results cannot be easily compared with a naturally occurring environment. As mentioned earlier, distilled water was used for experimental expediency and to facilitate interlaboratory comparisons of results.

In order to truly reflect the interactions of trace nuclides with geologic media after repository disruption and water contact, realistic concentrations of tracer must be used in spiked experiments. Concentrations much higher than probable may have a significant biasing effect and should be avoided. The activity and concentration of radiotracers added to the influents are reported in Table 8. As several of the tracer solutions were not free of carrier element, the total concentration of each element added to the solutions is estimated in the third column.

Table 8. Initial Activity of Batch Influents

\begin{tabular}{|c|c|c|c|c|}
\hline & $\mu \mathrm{C}^{\mathrm{T}}$ & $i / 1$ & $\begin{array}{l}\mu \mathrm{g} / 1 \text { (Assuming } \\
\text { Carrier Free) }\end{array}$ & $\mu \mathrm{g} / 1$ (Estimated) \\
\hline & 0.65 & & $2.73 \times 10^{-5}$ & $2.73 \times 10^{-2^{\star}}$ \\
\hline & 8.12 & & $2.43 \times 10^{-3}$ & $2.43 \times 10^{-3}$ \\
\hline & 4.49 & & $1.41 \times 10^{-3}$ & $1.41 \times 10^{-3}$ \\
\hline & 10.90 & & $5.92 \times 10^{-2}$ & 1.2 \\
\hline & 5.27 & & $5.09 \times 10^{-3}$ & $5.09 \times 10^{-3}$ \\
\hline & 2.03 & & $2.33 \times 10^{-2}$ & $2.33 \times 10^{-2 \star \star}$ \\
\hline & 0.03 & -0.26 & $40-370$ & $40-370$ \\
\hline & 0.06 & -0.78 & $0.2-2.4 \times 10^{-1}$ & $0.2-2.4 \times 10^{-1}$ \\
\hline & 0.002 & -0.008 & $3.9-8.7 \times 10^{3}$ & $3.9-8.7 \times 10^{3}$ \\
\hline & 0.003 & -0.023 & $0.3-1.9 \times 10^{-6}$ & $0.3-1.9 \times 10^{-6}$ \\
\hline & 0.0006 & -0.005 & $0.3-2.4 \times 10^{-7}$ & $0.3-2.4 \times 10^{-7}$ \\
\hline & 0.02 & -0.07 & $0.4-1.5 \times 10^{-3}$ & $0.4-1.5 \times 10^{-3}$ \\
\hline
\end{tabular}

\footnotetext{
*Brines have 5,000 to $20,000 \mu \mathrm{g} / 1$ stable element **Brines have 1,000 to $10,000 \mu \mathrm{g} / 1$ stable element
} 
For comparison the range of maximum concentrations of fission products and actinides found upon leaching several pieces of $v 10$ grams of Battelle high level zinc borosilicate glass (19 $\mathrm{cm}^{2}$ geometric surface area) in $500 \mathrm{ml}$ of distilled water are shown in Table 9 (D. J. Bradley, Battelle Northwest data to be published).

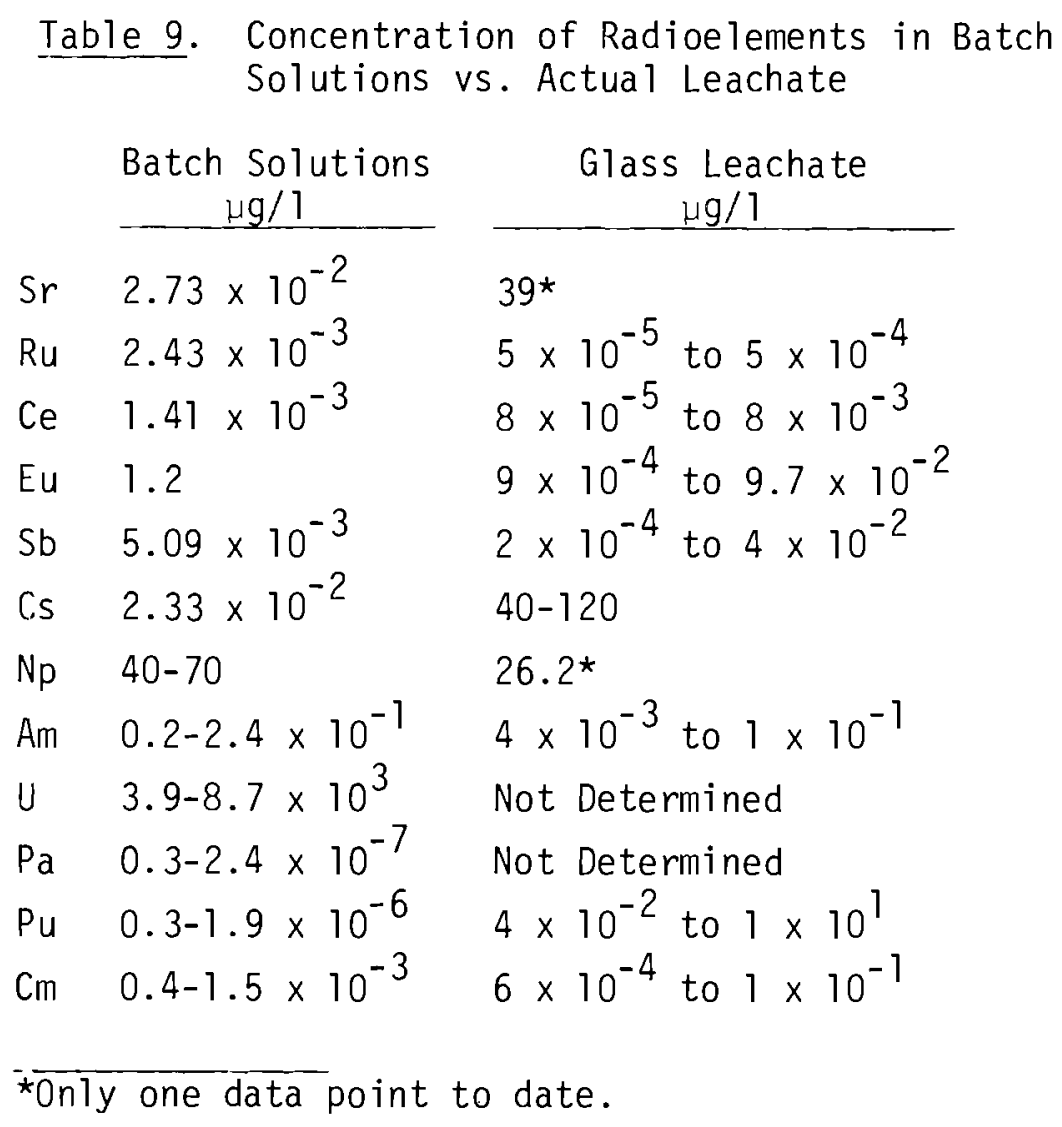

The concentrations of radioelements found in the actual leachate are for a 30 day static leach in distilled water. The actual leached concentrations which will be found in a waste repository are probably less. The actual concentration of stable fission product elements found in groundwaters will, in most cases, be controlled by the concentration of leached stable, naturally occurring isotopes. Thus, the amount of tracer to add to batch Kd experiments for fission products to approximate the concentration in groundwaters should consider data available for average groundwaters which, for rare earth elements, runs in the parts per trillion-parts per billion range and for alkaline earths and alkali metals are in the low parts per million range. 
In a 11 cases (with the exception of $U$ and Eu) the absolute concentrations of tracer used in these batch Kd experiments are of the correct order of magnitude, or lower, than observed leach concentrations. Thus, the $k d$ results presented herein are realistic from a tracer concentration view point.

One complicating factor not addressed in this preliminary study which could affect the actinide Kd's significantly is the possibility of anionic complex formation (for example, chloro complexes in a $\mathrm{NaCl}$ rich system) and variable valence states. $\mathrm{Pu}$, Np, and $U$ especially may be present in the repository environment in numerous valence states or complexes which could lead to a wide variation in $\mathrm{Kd}$. Several studies on the migration behavior of actinides of various oxidation states on various rock samples, of the oxidation state of actinides leached from waste, and of actinide chemistry in neutral solutions have been conducted or are planned at Argonne National Laboratory $(7,8)$ and Battelle Pacific Northwest Labs. (9) In this study, the isotopes are assumed to be predominately in their most stable valence states for neutral groundwaters in equilibrium with the atmosphere, i.e., $\mathrm{Pu}^{+4}$, $\mathrm{Am}^{+3}, \mathrm{~Np}^{+5}\left(\mathrm{NpO}_{2}^{+}\right), \mathrm{Cm}^{+3}, \mathrm{U}^{+6}\left(\mathrm{UO}_{2}^{+2}\right)$. Rai and Serne, $(10)$ and Ames, Rai and Serne $(11)$ discuss the thermodynamic data on aqueous actinide chemistry.

The $\mathrm{pH}$ of the slurries of rock and solutions after each cold wash are shown in Table 10.

The $\mathrm{pH}$ of Brine "B" and distilled water after cold washes were one $\mathrm{pH}$ unit greater than initial values reflecting the alkaline buffering capacity of the rocks. After two cold washes of Brine "XA" and Brine "XB", and groundwater " $\mathrm{C}$ ", the $\mathrm{pH}$ reached the desired value. The $\mathrm{pH}$ values of the effluents as a function of transporting solution, equilibration times, and nuclide mixture are shown in Table 1la through 11c.

Resultant Kd values for each nuclide versus rock type, solution type and equilibration time are shown in Tables 12a-d, 13a-b, 14a-d, and 15a-b. Tables $12 a-d$ and $13 a-b$ portray the $K d$ data for fission products and actinides respectively in units of $\mathrm{ml} / \mathrm{g}$ (porous flow). Tables $14 \mathrm{a}-\mathrm{d}$ and $15 a-b$ portray the $\mathrm{Kd}$ data for fission products and actinides respectively in 
Table 10. pH of Cold Washes

\begin{tabular}{|c|c|c|c|c|c|c|c|c|c|c|c|}
\hline & & Distil & ed $\mathrm{H}_{2} \mathrm{O}$ & Brine & "XA" & Brine & "XB" & Brin & "B" & Groundw & er \\
\hline & Rock & lst & $\underline{2 n d^{2}}$ & $1 \mathrm{st}$ & 2nd & $\underline{1 s t}$ & 2nd & 1st & 2nd & $1 \mathrm{st}$ & 2nd \\
\hline & Magenta & 8.2 & 8.9 & 6.5 & - & 6.7 & 6.6 & - & - & - & - \\
\hline & Culebra & 8.6 & 8.9 & 6.6 & - & 6.7 & 6.7 & 7.5 & 7.5 & 7.7 & 7.6 \\
\hline & Cherry Canyon \#1 & 7.8 & 8.9 & 6.6 & 6.6 & 6.8 & 6.8 & 7.2 & 7.2 & 7.8 & 7.8 \\
\hline - & Cherry Canyon \#2 & 8.1 & 8.7 & 6.6 & - & 6.7 & 6.7 & - & - & - & - \\
\hline & Cherry Canyon \#3 & 8.4 & 8.8 & 6.5 & - & 6.7 & 6.7 & - & - & - & - \\
\hline
\end{tabular}

- Not available 
Table 11a. Effluent pH

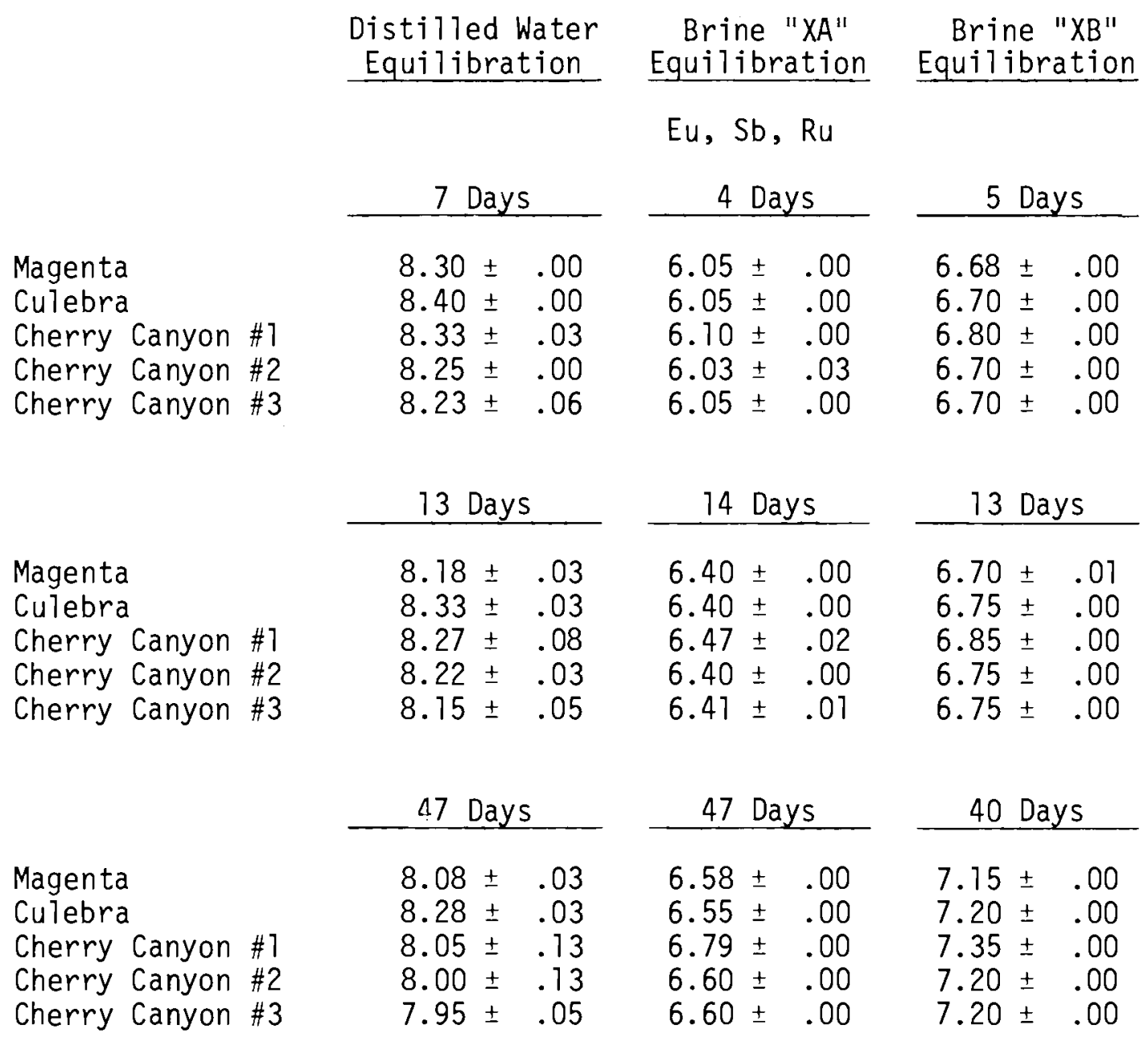


Table 11b. Effluent pH

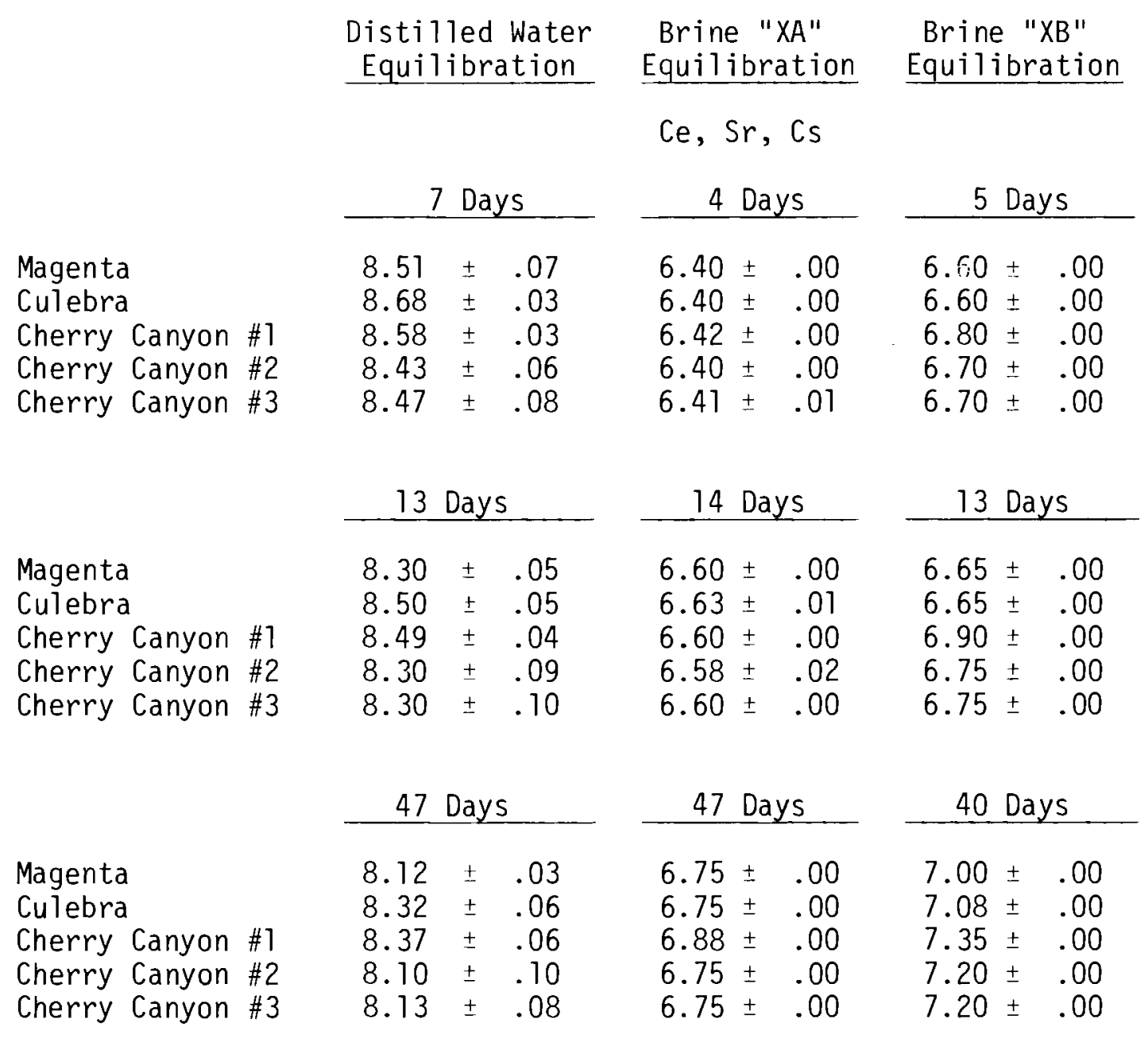


Table 11c. Effluent pH

\begin{tabular}{|c|c|c|}
\hline & $\begin{array}{c}\text { Brine "B" } \\
\text { Equilibration } \\
\end{array}$ & $\begin{array}{l}\text { Groundwater "C" } \\
\text { Equilibration } \\
\end{array}$ \\
\hline & \multicolumn{2}{|c|}{$\mathrm{Cm}-U$} \\
\hline & 5 Days & 5 Days \\
\hline \multirow[t]{2}{*}{$\begin{array}{l}\text { Culebra } \\
\text { Cherry Canyon \#1 }\end{array}$} & $\begin{array}{l}7.67 \pm .15 \\
7.67 \pm .10\end{array}$ & $\begin{array}{l}8.09 \pm .01 \\
8.23 \pm .03\end{array}$ \\
\hline & 8 Days & 8 Days \\
\hline \multirow[t]{3}{*}{$\begin{array}{l}\text { Culebra } \\
\text { Cherry Canyon \#1 }\end{array}$} & $\begin{array}{l}6.53 \pm .06 \\
6.68 \pm .03\end{array}$ & $\begin{array}{l}7.50 \pm .00 \\
7.55 \pm .01\end{array}$ \\
\hline & Am, 1 & , $\mathrm{Pa}$ \\
\hline & 5 Days & 5 Days \\
\hline \multirow[t]{2}{*}{$\begin{array}{l}\text { Culebra } \\
\text { Cherry Canyon \#1 }\end{array}$} & $\begin{array}{l}6.93 \pm .49 \\
7.40 \pm .06\end{array}$ & $\begin{array}{ll}8.03 & \pm .03 \\
8.21 & \pm .01\end{array}$ \\
\hline & 8 Days & 8 Days \\
\hline \multirow[t]{3}{*}{$\begin{array}{l}\text { Culebra } \\
\text { Cherry Canyon \#1 }\end{array}$} & $\begin{array}{l}6.55 \pm .17 \\
6.66 \pm .04\end{array}$ & $\begin{array}{l}7.39 \pm .01 \\
7.52 \pm .07\end{array}$ \\
\hline & & \\
\hline & 8 Days & 8 Days \\
\hline \multirow[t]{3}{*}{$\begin{array}{l}\text { Culebra } \\
\text { Cherry Canyon \#1 }\end{array}$} & $\begin{array}{l}6.83 \pm .06 \\
6.78 \pm .03\end{array}$ & $\begin{array}{l}7.42 \pm .10 \\
7.52 \pm .03\end{array}$ \\
\hline & Cs, & , Tc \\
\hline & 16 Days & 16 Days \\
\hline $\begin{array}{l}\text { Culebra } \\
\text { Cherry Canyon \#1 }\end{array}$ & $\begin{array}{l}6.52 \pm .03 \\
6.58 \pm .03\end{array}$ & $\begin{array}{l}7.51 \\
7.48 .01 \\
7.48\end{array}$ \\
\hline
\end{tabular}


Table 12a. Fission Product $\mathrm{Kd}$ 's $(\mathrm{ml} / \mathrm{g})$

Magenta

Culebra

Cherry Canyon \# 1

Cherry Canyon \#2

Cherry Canyon \#3

Magenta

Culebra

Cherry Canyon \#1

Cherry Canyon \#2

Cherry Canyon \#3

Magenta

Culebra

Cherry Canyon \#1

Cherry Canyon \#2

Cherry Canyon \#3

Magenta

Culebra

Cherry Canyon \#1

Cherry Canyon \#2

Cherry Canyon \#3

Magenta

Culebra

Cherry Canyon \#1

Cherry Canyon \#2

Cherry Canyon \#3

Magenta

Culebra

Cherry Canyon \#1

Cherry Canyon \#2

Cherry Canyon \#3

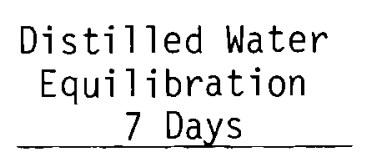

Brine "XA"

Equilibration 4 Days

$\mathrm{Kd}_{\mathrm{Eu}}$

$\begin{array}{rrr}451 & \pm 102 \\ 359 & \pm & 87 \\ 272 & \pm 105 \\ 113 & \pm 10 \\ 91 & \pm 14\end{array}$

$48.3 \pm 14.9$

$87.2 \pm 5.2$

$69.4 \pm 6.5$

$24.6 \pm 8.0$

$35.8 \pm 6.1$

$\mathrm{Kd}_{\mathrm{Sb}}$

$3.7 \pm$

$2.4 \pm$

1.2

0.2

$1.6 \pm$

0.6

$3.2 \pm$

0.2

$2.8 \pm 1.8$

$-0.1 \pm 0.8$

$-0.4 \pm 0.4$

$-0.5 \pm 0.8$

$-2.1 \pm 2.5$

$0.2 \pm 1.3$

$\mathrm{Kd}_{\mathrm{Ru}}$

$99.8 \pm$
$81.4 \pm$

$81.4 \pm$
$63.2 \pm$

$68.3 \pm$

$62.8 \pm$

12.
6.3
7.7
4.
10.

12.2

$1.9 \pm 1.2$

$3.6 \pm 0.2$

$2.7 \pm 0.4$

$1.9 \pm 0.2$

$2.0 \pm 1.0$

10.3

${ }^{\mathrm{Kd}} \mathrm{Ce}$

$\begin{array}{rrr}466 & \pm 446 \\ 1360 & \pm 2015 \\ 210 & \pm 169 \\ 496 & \pm 344\end{array}$$$
\begin{array}{rrrrr}
22.7 \pm 2.1 & 408 & \pm & 180 \\
39.3 \pm 7.8 & 706 & \pm & 374 \\
58.6 \pm 27.5 & 5060 & \pm & 5906 \\
28.1 \pm 11.0 & 147 & \pm & 18 \\
20.5 \pm 4.0 & 115 & \pm & 20
\end{array}
$$

$\mathrm{Kd}_{\mathrm{Sr}}$

$5.6 \pm$

0.2

$$
-0
$$

$-0.3 \pm$

0.5

0.3

$12.4 \pm$

1. 2

0.1

$37.5 \pm$

1.2

$-0.4 \pm$

0.4

$19.2 \pm$

1.5

$-0.2 \pm$

0.3

$3.0 \pm$

0.5

$4.1 \pm$

0.4

$3.5 \pm$

0.9

$3.7 \pm$

0.1

$3.9 \pm$

0.4
Brine "XB"
Equilibration 5 Days

$\begin{array}{lr}54.6 \pm & 4.7 \\ 54.2 \pm & 8.4 \\ 61.6 \pm & 15.1 \\ 35.3 \pm & 11.2 \\ 35.4 \pm & 4.5\end{array}$


Table 12b. Fission Product $\mathrm{Kd}$ 's $(\mathrm{ml} / \mathrm{g})$

Magenta
Culebra
Cherry Canyon \#1
Cherry Canyon \#2
Cherry Canyon \#3

Magenta
Culebra
Cherry Canyon \#1
Cherry Canyon \#2
Cherry Canyon \#3

Magenta

Culebra

Cherry Canyon \#1 Cherry Canyon \#2 Cherry Canyon \#3

Magenta

Culebra

Cherry Canyon \#1

Cherry Canyon \#2

Cherry Canyon \#3

Magenta

Culebra

Cherry Canyon \#1

Cherry Canyon \#2

Cherry Canyon \#3

Magenta

Culebra

Cherry Canyon \#1

Cherry Canyon \#2

Cherry Canyon \#3 \begin{tabular}{c} 
Distilled Water \\
Equilibration \\
13 Days \\
\hline
\end{tabular}

$\mathrm{Kd}_{\mathrm{Eu}}$

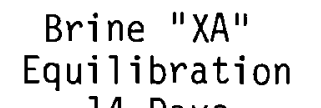

14 Days

$56.2 \pm 4.8$

$96.7 \pm 1.3$

$84.8 \pm 5.4$

$27.1 \pm 0.4$

$42.7 \pm 0.9$
Brine "XB"

Equilibration 13 Days

$\begin{array}{rrrrrrr}640 & \pm & 302 & 56.2 \pm 4.8 & 46.2 \pm & 10.8 \\ 639 & \pm & \pm 42 & 96.7 \pm 1.3 & 61.2 \pm & 16.8 \\ 459 & \pm & 54 & 84.8 \pm 5.4 & 56.4 \pm & 19.1 \\ 203 & \pm & 57 & 27.1 \pm 0.4 & 22.0 \pm & 6.9 \\ 171 & \pm & 39 & 42.7 \pm 0.9 & 30.1 \pm & 13.0\end{array}$

$\mathrm{Kd}_{\mathrm{Sb}}$
$5.3 \pm$
0.3
$0.4 \pm$
0.9
$1.2 \pm$
0.7
$3.2 \pm$
0.7
$2.1 \pm$
$-0.3 \pm$
0.7
$0.2 \pm 0.6$
$4.6 \pm 0.5$
$0.4 \pm 0.2$
$3.1 \pm$
0.2
$-0.0 \pm 0.4$
$1.5 \pm$
0.7
$0.9 \pm$
0.3
$5.2 \pm 0.5$
$1.6 \pm 0.4$

$\mathrm{Kd}_{\mathrm{Ru}}$

$153.6 \pm 9.0$

$134.3 \pm 9.7$

$94.4 \pm 6.0$

$119.2 \pm 3.6$

$94.5 \pm$

6.1

$3.0 \pm 0.8$

$5.1 \pm 1.0$

$4.8 \pm 0.4$

$3.6 \pm 0.3$

$3.4 \pm 0.2$

$3.7 \pm$

0.3

$5.3 \pm$

0.1

$5.6 \pm 2.0$

$6.4 \pm 0.3$

$5.4 \pm 0.3$

${ }^{\mathrm{Kd}} \mathrm{Ce}$

$$
\begin{array}{rr}
797 & \pm 944 \\
1364 & \pm 2040 \\
170 & \pm 130 \\
930 & \pm 1392 \\
2540 & \pm 2040
\end{array}
$$

$\begin{array}{rrrr}22.5 \pm 7.7 & 626 & \pm 113 \\ 54.8 \pm 17.8 & 791 & \pm 245 \\ 57.9 \pm 3.9 & 5264 & \pm 3750 \\ 28.5 \pm 13.0 & 174 & \pm & 43 \\ 26.0 \pm 13.2 & 148 & \pm & 23\end{array}$

$\mathrm{Kd}_{\mathrm{Sr}}$

$\begin{array}{rllrl}5.3 \pm & 0.1 & 1.0 \pm 0.3 & 0.6 \pm & 0.1 \\ 10.3 \pm & 0.7 & 0.7 \pm 0.6 & 0.6 \pm & 0.7 \\ 9.0 \pm & 1.2 & 0.9 \pm 0.7 & 0.1 \pm & 0.4 \\ 33.7 \pm & 2.9 & 1.1 \pm 0.5 & -0.1 \pm & 0.3 \\ 16.4 \pm & 1.8 & 0.7 \pm 0.4 & 0.4 \pm & 0.4\end{array}$

${ }^{\mathrm{Kd}} \mathrm{Cs}$

$\begin{aligned} 2345 & \pm 111 \\ 1809 & \pm 320 \\ 6995 & \pm 494 \\ 18560 & \pm 8200 \\ 6855 & \pm 1462\end{aligned}$

$0.3 \pm 0.3-0.2 \pm$

0.3

$\begin{array}{rrr}0.1 \pm 0.4 & -0.1 \pm 0.5\end{array}$

$0.4 \pm 0.5 \quad-0.1 \pm 0.1$

$1.0 \pm 0.5 \quad-0.1 \pm 0.1$

$0.4 \pm 0.4 \quad 0.0 \pm 0.2$ 
Table 12c. Fission Product Kd's (ml/g)

Magenta

Culebra

Cherry Canyon \#1

Cherry Canyon \#2

Cherry Canyon \#3

Magenta

Culebra

Cherry Canyon \#1

Cherry Canyon \#2

Cherry Canyon \#3

Magenta

Culebra

Cherry Canyon \#1

Cherry Canyon \#2

Cherry Canyon \#3

Magenta

Culebra

Cherry Canyon \#1

Cherry Canyon \#2

Cherry Canyon \#3

Magenta

Culebra

Cherry Canyon \#1

Cherry Canyon \#2

Cherry Canyon \#3

Magenta

Culebra

Cherry Canyon \#1

Cherry Canyon \#2

Cherry Canyon \#3
Distilled Water

Equilibration

\begin{tabular}{rlr}
\multicolumn{3}{c}{47 Days } \\
\hline & & \\
9873 & \pm & 4 \\
45584 & \pm & 49655 \\
1287 & \pm & 963 \\
$>1307$ & \pm & 698 \\
1163 & \pm & 95
\end{tabular}

Brine "XA"

Equilibration

47 Days

$\begin{array}{cl}\mathrm{Kd}_{\mathrm{Eu}} & \\ 34 & \pm \\ 50 & \pm 2 \\ 39 & \pm 4 \\ 8.3 & \pm 1.5 \\ 19 & \pm 1\end{array}$

$\mathrm{Kd}_{\mathrm{Sb}}$

$$
\mathrm{Kd}_{\mathrm{Sb}}
$$

Brine "XB"

Equilibration 40 Days

$\begin{array}{rrr}31 & \pm 9 \\ 31 & \pm 8 \\ 38 & \pm 15 \\ 21 & \pm 4 \\ 25 & \pm 10\end{array}$

$\begin{array}{lllllll}6.39 \pm & 0.64 & 0.73 & \pm & 0.45 & 1.7 \pm & 0.2 \\ 3.30 \pm & 1.40 & 1.07 & \pm & 0.45 & 1.9 \pm & 0.5 \\ 1.57 \pm & 0.11 & 0.22 \pm & 0.40 & 0.8 \pm & 0.2 \\ 5.99 \pm & 0.98 & 1.66 & \pm & 0.46 & 6.6 \pm & 0.4 \\ 2.80 \pm & 1.20 & 0.92 \pm & 0.36 & 1.9 \pm & 0.5\end{array}$

$\mathrm{Kd}_{\mathrm{Ru}}$

$\begin{array}{rrr}389 & \pm & 54 \\ 291 & \pm & 41 \\ 274 & \pm & 33 \\ 554 & \pm & 123 \\ 351 & \pm & 59\end{array}$

$3.6 \pm 0.3$

$5.6 \pm 0.4$

$7.5 \pm 0.2$

$10.2 \pm 0.2$

$6.3 \pm 0.3$

$8.5 \pm 4.0$

$6.1 \pm 0.5$

$9.9 \pm 0.0$

$5.8 \pm$

0.5

$8.9 \pm 0.7$

${ }^{\mathrm{Kd}} \mathrm{Ce}_{\mathrm{C}}$

$\begin{array}{rrrrrrr}71 & \pm & 61 & 19 & \pm 20 & 179 & \pm 63 \\ 108 & \pm & 100 & 8 & \pm 2 & 227 & \pm 32 \\ >310 & \pm & & 13 & \pm 8 & >608 & \pm \\ 293 & \pm & 189 & 22 & \pm 20 & 106 & \pm 13 \\ 538 & \pm & 826 & 13 & \pm 18 & 62 & \pm 4\end{array}$

$\mathrm{Kd}_{\mathrm{Sr}}$

$\begin{array}{rccccccc}8 & \pm & 4 & 0.4 & \pm 0.3 & -0.4 \pm 0.4 \\ 8 & \pm & 0.3 & 0.6 & \pm 0.5 & 0.3 \pm & 0.4 \\ 13 & \pm & 10 & 0.4 & \pm 0.3 & 0.7 \pm & 0.2 \\ 22 & \pm & 2 & 0.7 & \pm 0.7 & 0.1 \pm & 0.2 \\ 12 & \pm & 3 & 1.0 & \pm 0.6 & 0.1 \pm & 0.2\end{array}$


Table 12d. Fission Product Kd's (ml/g)

\begin{tabular}{|c|c|c|}
\hline & $\begin{array}{c}\text { Brine "B" } \\
\text { Equilibration } \\
16 \text { Days }\end{array}$ & $\begin{array}{c}\text { Groundwater "C" } \\
\text { Equilibration } \\
16 \text { Days } \\
\end{array}$ \\
\hline & \multicolumn{2}{|c|}{$\mathrm{Kd}_{\mathrm{Tc}}$} \\
\hline $\begin{array}{l}\text { Culebra } \\
\text { Cherry Canyon \#1 }\end{array}$ & $\begin{array}{l}0.24 \pm 0.97 \\
1.88 \pm 1.56\end{array}$ & $\begin{array}{l}0.47 \pm 0.84 \\
6.70 \pm 4.80\end{array}$ \\
\hline $\begin{array}{l}\text { Culebra } \\
\text { Cherry Canyon \# }\end{array}$ & $\begin{array}{l}0.85 \pm 0.86 \\
0.62 \pm 0.84\end{array}$ & $\begin{array}{l}1.02 \pm 1.41 \\
1.67 \pm 2.11\end{array}$ \\
\hline $\begin{array}{l}\text { Culebra } \\
\text { Cherry Canyon \#1 }\end{array}$ & $\begin{array}{l}1.30 \pm 1.09 \\
1.14 \pm 1.10\end{array}$ & $\begin{array}{r}13.60 \pm 2.40 \\
4.15 \pm 3.75\end{array}$ \\
\hline
\end{tabular}


Table 13a. Actinide Kd's (ml/g)

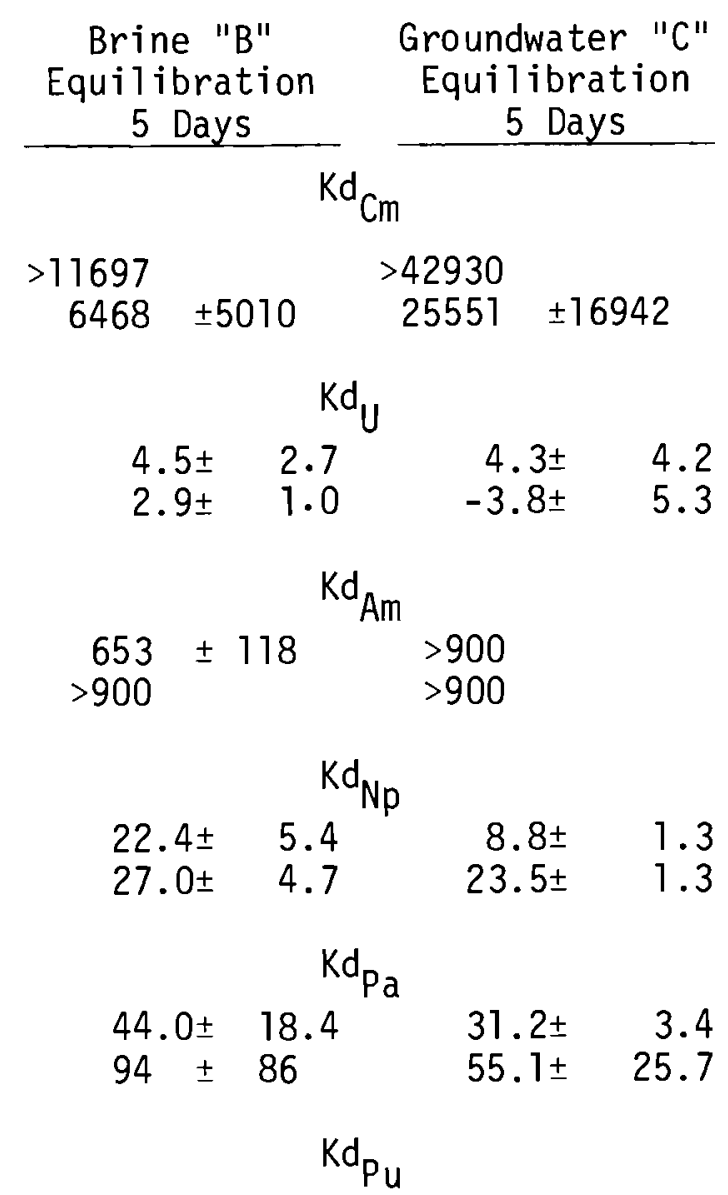

Culebra

Not Determined Not Determined

Cherry Canyon \#1

Not Determined

Not Determined 
Table 13b. Actinide $\mathrm{Kd}$ 's $(\mathrm{ml} / \mathrm{g})$

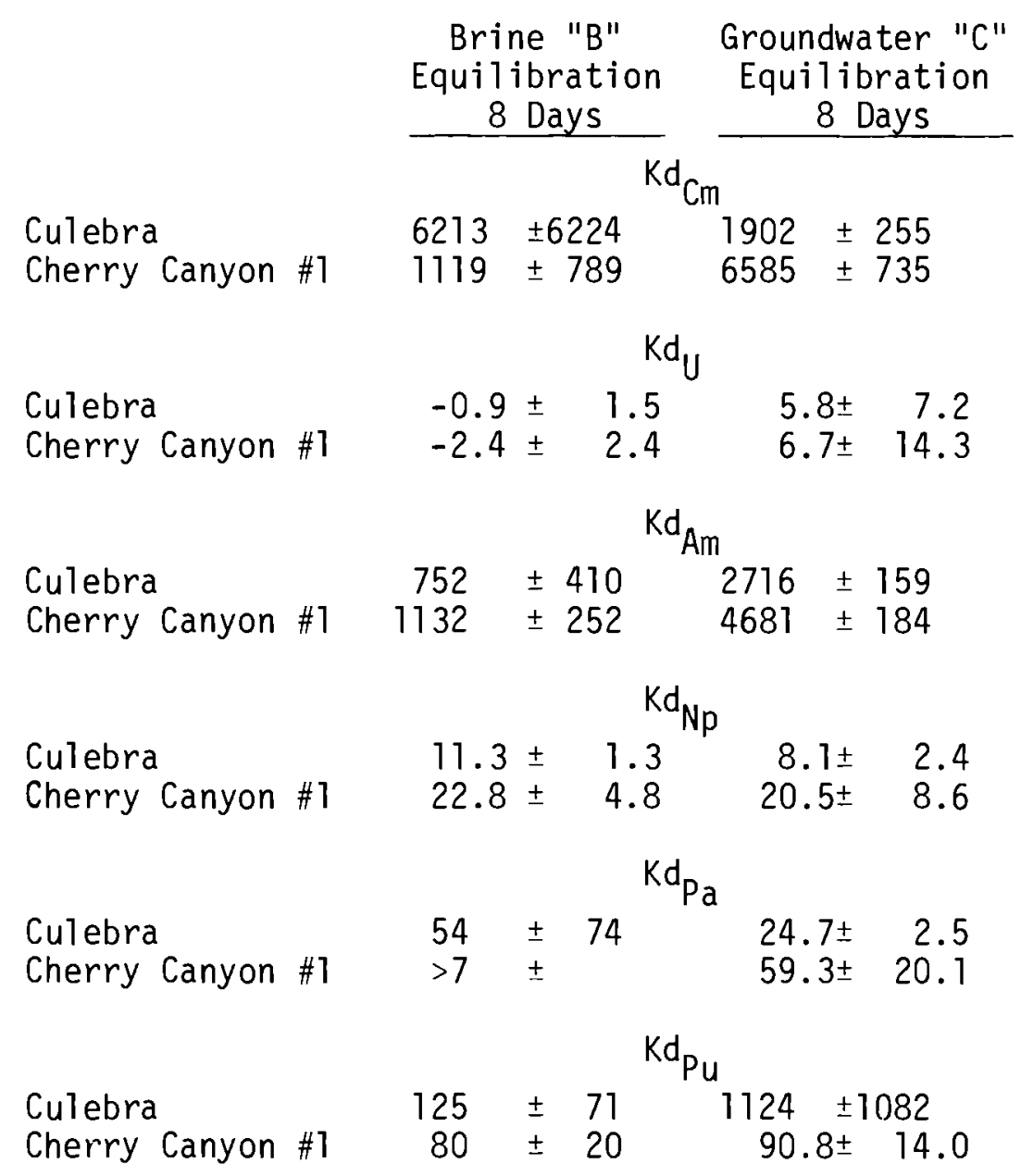


Table 14a. Fission Product $\mathrm{Kd}$ 's $\left(\mathrm{ml} / \mathrm{m}^{2}\right)$

Magenta
Cuelbra
Cherry Canyon \#1
Cherry Canyon \#2
Cherry Canyon \#3

Magenta

Culebra

Cherry Canyon \#1

Cherry Canyon \#2

Cherry Canyon \#3

Magenta
Culebra
Cherry Canyon \#1
Cherry Canyon $\# 2$
Cherry Canyon $\# 3$

Magenta

Culebra

Cherry Canyon \#1

Cherry Canyon \#2

Cherry Canyon \#3

Magenta
Culebra
Cherry Canyon \#1
Cherry Canyon \#2
Cherry Canyon \#3

Magenta

Culebra

Cherry Canyon \#1

Cherry Canyon \#2

Cherry Canyon \#3

\begin{tabular}{c}
$\begin{array}{c}\text { Distilled Wate } \\
\text { Equil ibration } \\
7 \\
\text { Days }\end{array}$ \\
\hline
\end{tabular}

Brine "XA"

Equilibration 4 Days

$$
\mathrm{Kd}_{\mathrm{Eu}}
$$

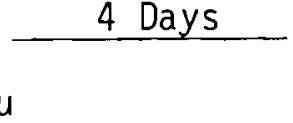

$$
\begin{array}{r}
5.96 \pm 1.84 \\
12.28 \pm 0.73 \\
53.38 \pm 5.00 \\
4.73 \pm 1.54 \\
3.25 \pm 0.55
\end{array}
$$

Brine "XB"

Equilibration

5 Days

$\mathrm{Kd}_{\mathrm{Sb}}$

$\begin{array}{llrrrr}0.5 \pm & 0.2 & -0.01 \pm & 0.10 & 0.15 \pm & 0.10 \\ 0.3 \pm & 0.0 & -0.05 \pm & 0.05 & 0.13 \pm & 0.11 \\ 1.2 \pm & 0.5 & -0.40 \pm & 0.58 & -0.06 \pm & 0.04 \\ 0.6 \pm & 0.0 & -0.40 \pm & 0.48 & 0.60 \pm & 0.02 \\ 0.3 \pm & 0.2 & 0.02 \pm & 1.18 & 0.10 \pm & 0.04\end{array}$

$\mathrm{Kd}_{\mathrm{Ru}}$

$\begin{array}{rlllll}12.3 \pm & 1.5 & 0.23 \pm & 0.15 & 0.37 \pm & 0.06 \\ 11.5 \pm & 0.9 & 0.51 \pm & 0.03 & 0.58 \pm & 0.06 \\ 48.6 \pm & 5.9 & 2.08 \pm & 0.31 & 2.68 \pm & 0.66 \\ 13.1 \pm & 0.8 & 0.37 \pm & 0.15 & 2.88 \pm & 0.02 \\ 5.7 \pm & 0.9 & 0.18 \pm & 0.09 & 0.35 \pm & 0.04\end{array}$

${ }^{\mathrm{Kd}} \mathrm{Ce}$

$57.5 \pm 55.1 \quad 2.80 \pm 0.26$

$191.6 \pm 283.8 \quad 5.54 \pm 1.10$

$161.6 \pm 130.0 \quad 45.08 \pm 21.15$

$95.4 \pm 66.2 \quad 5.40 \pm 2.12$

$9.1 \pm 0.6 \quad 1.86 \pm 0.36$

$6.74 \pm 0.58$

$7.63 \pm 1.18$

$47.38 \pm 11.62$

$6.79 \pm 2.15$

$3.22 \pm 0.41$

$\mathrm{Kd}_{\mathrm{Sr}}$

$0.7 \pm 0.0-0.04 \pm 0.06 \quad-0.02 \pm 0.04$

$1.8 \pm 0.2-0.11 \pm 0.04 \quad-0.04 \pm 0.04$

$7.4 \pm 0.8-0.31 \pm 0.77 \quad 0.06 \pm 0.06$

$7.2 \pm 0.2-0.04 \pm 0.05 \quad-0.05 \pm 0.04$

$1.8 \pm$

$0.2-0.04 \pm 0.03$

$-0.04 \pm 0.04$

$\mathrm{Kd}_{\mathrm{Cs}}$

$328 \pm 11 \quad-0.04 \pm 0.06 \quad 0.02 \pm 0.04$

$245 \pm 8 \quad-0.08 \pm 0.04 \quad 0.02 \pm 0.01$

$5783 \pm 528 \quad-0.04 \pm 0.22$

$0.17 \pm 0.14$

$0.03 \pm 0.07$

$0.10 \pm 0.01$

$3571 \pm 1115$

$-0.03 \pm 0.01$

$0.04 \pm 0.02$ 
Table 14b. Fission Product Kd's $\left(\mathrm{ml} / \mathrm{m}^{2}\right)$

Magenta
Culebra
Cherry Canyon \#1
Cherry Canyon \#2
Cherry Canyon \#3

Magenta

Culebra

Cherry Canyon \#1

Cherry Canyon \#2

Cherry Canyon \#3

Magenta

Culebra

Cherry Canyon \#1

Cherry Canyon \#2

Cherry Canyon \#3

Magenta

Culebra

Cherry Canyon \#1

Cherry Canyon \#2

Cherry Canyon \#3

Magenta

Culebra

Cherry Canyon \#1

Cherry Canyon \#2

Cherry Canyon \#3

Magenta

Culebra

Cherry Canyon \#1

Cherry Canyon \#2

Cherry Canyon \#3

\begin{tabular}{c} 
Distilled Water \\
Equilibration \\
13 Days \\
\hline
\end{tabular}

Brine "XA"

Equilibration 14 Days

$$
K d_{E u}
$$

$\begin{array}{rrr}79 & \pm & 37 \\ 90 & \pm & 42 \\ 353 & \pm & 41 \\ 39 & \pm & 11 \\ 15 & \pm & 3\end{array}$

$11.7 \pm 0.6$

$48.2 \pm 0.2$

$65.2 \pm 4.1$

$5.2 \pm 0.1$

$3.9 \pm 0.1$

$\mathrm{Kd}_{\mathrm{Sb}}$

$0.7 \pm 0.1 \quad 0.05 \pm 0.11$

$0.5 \pm 0.1 \quad-0.04 \pm 0.10$

$\begin{array}{lll}0.5 \pm & \pm .4 & 0.15 \pm 0.46\end{array}$

$0.9 \pm 0.1 \quad 0.08 \pm 0.04$

$0.3 \pm$

0.0

$0.00 \pm 0.04$

$\mathrm{Kd}_{\mathrm{Ru}}$

$\begin{array}{rrr}19 & \pm & 1 \\ 19 & \pm & 1 \\ 73 & \pm & 5 \\ 23 & \pm & 1 \\ 9 & \pm & 1\end{array}$

$0.37 \pm 0.10$

$0.72 \pm 0.14$

$3.69 \pm 0.31$

$0.69 \pm 0.06$

$0.31 \pm 0.02$

$\mathrm{Kd}_{\mathrm{Ce}}$

$\begin{array}{rrr}98 & \pm & 117 \\ 192 & \pm & 287 \\ 131 & \pm & 100 \\ 179 & \pm & 268 \\ 231 & \pm & 185\end{array}$

$2.78 \pm 0.95$

$7.72 \pm 2.51$

$44.54 \pm 3.00$

$5.48 \pm 2.50$

$2.36 \pm 1.20$

$\mathrm{Kd}_{\mathrm{Sr}}$

$\begin{array}{ll}1 & \pm \\ 1 & \pm \\ 7 & \pm \\ 6 & \pm \\ 1 & \pm\end{array}$

0.0

0.1

0.1

$0.12 \pm 0.04$

$0.10 \pm 0.08$

0.9

$0.69 \pm 0.54$

0.6

$0.21 \pm 0.10$

$0.06 \pm 0.04$

${ }^{\mathrm{Kd}} \mathrm{Cs}$

$\begin{array}{rlr}290 & \pm & 14 \\ 260 & \pm & 45 \\ 5381 & \pm & 380 \\ 3569 & \pm & 1577 \\ 623 & \pm & 133\end{array}$

$0.04 \pm 0.04$

$-0.01 \pm 0.06$

$0.31 \pm 0.38$

$0.19 \pm 0.10$

$0.04 \pm 0.04$
Brine "XB"

Equilibration

13 Days

5.7
$8.6 \pm 1.3$
$43.4 \pm 2.4$
$4.2 \pm 14.7$
$2.7 \pm 1.3$

$0.15 \pm 0.09$

$0.21 \pm 0.10$

$0.69 \pm 0.23$

$1.0 \pm 0.10$

$0.15 \pm 0.04$

$0.46 \pm 0.04$

$0.75 \pm 0.01$

$4.31 \pm 1.54$

$1.23 \pm 0.06$

$0.49 \pm 0.03$

$$
\begin{array}{rlr}
77.28 & \pm 13.95 \\
111.41 & \pm 34.51 \\
4049.23 & \pm 2884.62 \\
33.46 \pm & 8.27 \\
13.45 \pm & 2.09 \\
& & \\
0.07 & \pm & 0.01 \\
0.08 & \pm & 0.10 \\
0.08 & \pm & 0.31 \\
-0.02 & \pm & 0.06 \\
0.04 & \pm & 0.04
\end{array}
$$

$\begin{array}{r}-0.02 \pm \\ -0.01 \pm 0.04 \\ -0.08 \pm 0.07 \\ -0.02 \pm 0.08 \\ 0.00 \pm 0.02 \\ \hline\end{array}$


Table 14c. Fission Product $\mathrm{Kd}$ 's $\left(\mathrm{ml} / \mathrm{m}^{2}\right)$

Magenta

Culebra

Cherry Canyon \#1

Cherry Canyon \#2

Cherry Canyon \#3

Magenta

Culebra

Cherry Canyon \#1

Cherry Canyon \#2

Cherry Canyon \#3

Magenta

Culebra

Cherry Canyon \#1

Cherry Canyon \#2

Cherry Canyon \#3

Magenta

Culebra

Cherry Canyon \#1

Cherry Canyon \#2

Cherry Canyon \#3

Magenta

Culebra

Cherry Canyon \#1

Cherry Canyon \#2

Cherry Canyon \#3

Magenta

Culebra

Cherry Canyon \#1

Cherry Canyon \#2

Cherry Canyon \#3 \begin{tabular}{c} 
Distilled Water \\
Equilibrium \\
47 Days \\
\hline
\end{tabular}

Brine "XA"

Equilibration

47 Days

$\mathrm{Kd}_{\mathrm{Eu}}$

$\begin{array}{rrr}1219 & \pm & 1 \\ 6420 & \pm & 6994 \\ 990 & \pm & 741 \\ >251 & \pm & 134 \\ 106 & \pm & 9\end{array}$

$4.20 \pm 0.62$

$7.04 \pm 0.28$

$30.00 \pm 3.08$

$1.60 \pm 0.29$

$1.73 \pm 0.09$

$\mathrm{Kd}_{\mathrm{Sb}}$

$0.8 \pm$

0.1

$0.09 \pm 0.06$

$0.5 \pm$

0.2

$1.2 \pm$

0.1

$1.2 \pm$

0.2

$0.15 \pm 0.06$

$0.17 \pm 0.31$

$0.3 \pm$

0.1

$0.32 \pm 0.09$

$0.08 \pm 0.03$

$\mathrm{Kd}_{\mathrm{Ru}}$

$\begin{array}{rrr}48 & \pm & 7 \\ 41 & \pm & 6 \\ 211 & \pm & 25 \\ 107 & \pm & 24 \\ 32 & \pm & 5\end{array}$

$0.44 \pm 0.04$

$1.06 \pm 0.03$

$4.85 \pm 0.23$

$1.17 \pm 0.10$

$0.53 \pm 0.05$

$\mathrm{Kd}_{\mathrm{Ce}}$

$\begin{array}{rlr}9 & \pm & 8 \\ 15 & \pm & 14 \\ >239 & \pm & \\ 56 & \pm & 36 \\ 49 & \pm & 75\end{array}$

$2.35 \pm 2.47$

$1.13 \pm 0.28$

$10.00 \pm 6.15$

$4.23 \pm 3.85$

$1.18 \pm 1.64$

$\mathrm{Kd}_{\mathrm{Sr}}$

$\begin{array}{rr}1 & \pm \\ 1 & \pm \\ 10 & \pm \\ 4 & \pm \\ 1 & \pm\end{array}$

0.5

$0.05 \pm 0.04$
$0.08 \pm 0.07$

0.0

7.7

$0.31 \pm 0.23$

$0.13 \pm 0.13$

0.4

$0.09 \pm 0.05$

$0.23 \pm 0.02$

$0.27 \pm 0.07$

$0.62 \pm 0.38$

$1.27 \pm 0.08$

$0.17 \pm 0.05$

$3.83 \pm 1.11$

$4.37 \pm 1.13$

$29.23 \pm 11.54$

$4.04 \pm 3.08$

$2.27 \pm 0.91$

Equilibration

40 Days$$
0.17 \pm
$$

$0.69 \pm 0.05$

$1.44 \pm 0.03$

$6.54 \pm 3.08$

$1.90 \pm 0.00$

$0.81 \pm 0.06$

$$
\begin{array}{r}
22.10 \pm 7.78 \\
31.97 \pm 4.51 \\
467.69 \\
20.38 \pm 2.50 \\
5.64 \pm 0.36
\end{array}
$$$$
\begin{array}{r}
-0.05 \pm \\
0.04 \pm 0.05 \\
-0.54 \pm 0.06 \\
0.02 \pm 0.15 \\
0.01 \pm 0.02
\end{array}
$$

${ }^{\mathrm{Kd}} \mathrm{Cs}$

$$
\begin{array}{rlrr}
276 & \pm & \multicolumn{3}{c}{\text { Cs }} & -0.06 \pm 0.02 \\
16 & \pm & 3 & -0.03 \pm 0.07 \\
5031 & \pm 1385 & -0.62 \pm 0.08 \\
2344 & \pm & 134 & 0.06 \pm 0.10 \\
477 & \pm 154 & -0.00 \pm 0.03
\end{array}
$$

$-0.02 \pm$
$-0.01 \pm 0.04$
$0.08 \pm 0.10$
$0.12 \pm 0.15$
$-0.01 \pm 0.01$


Table 14d. Fission Product $\mathrm{Kd}$ 's $\left(\mathrm{ml} / \mathrm{m}^{2}\right)$

Culebra

Cherry Canyon \#1

\begin{tabular}{|c|c|}
\hline $\begin{array}{c}\text { Brine "B" } \\
\text { Equilibration } \\
16 \text { Days } \\
\end{array}$ & $\begin{array}{c}\text { Groundwater "C' } \\
\text { Equilibration } \\
16 \text { Days } \\
\end{array}$ \\
\hline \multicolumn{2}{|c|}{$\mathrm{Kd}_{\mathrm{TC}}$} \\
\hline $\begin{array}{l}0.03 \pm 0.14 \\
1.45 \pm 1.20\end{array}$ & $\begin{array}{l}0.07 \pm .12 \\
5.15 \pm 3.69\end{array}$ \\
\hline
\end{tabular}

Culebra

Cherry Canyon \#1

$0.12 \pm 0.12$

$0.14 \pm 0.20$

$0.48 \pm 0.65$

$1.28 \pm 1.62$

Culebra

Cherry Canyon \#1

$\begin{array}{ll}{ }^{\mathrm{Kd}} \mathrm{Cs} \\ 0.18 \pm 0.15 & 1.92 \pm 0.34 \\ 0.88 \pm 0.85 & 3.19 \pm 2.88\end{array}$ 
Table 15a. Actinide $\mathrm{Kd}$ 's $\left(\mathrm{ml} / \mathrm{m}^{2}\right)$

Culebra
Cherry Canyon $\# 1$

\begin{tabular}{|c|c|c|}
\hline \multicolumn{2}{|c|}{$\begin{array}{c}\text { Brine "B" } \\
\text { Equilibration } \\
5 \text { Days }\end{array}$} & $\begin{array}{c}\text { Groundwater "C" } \\
\text { Equilibration } \\
5 \text { Days }\end{array}$ \\
\hline \multicolumn{3}{|c|}{$\mathrm{Kd}_{\mathrm{Cm}}$} \\
\hline $\begin{array}{r}>1647 \\
4975\end{array}$ & \pm 3854 & $\begin{array}{r}6046 \\
19654\end{array}$ \\
\hline
\end{tabular}

Culebra

Cherry Canyon \#1

$0.63 \pm$

$2.23 \pm$

0.38

$K d_{U}$

Culebra

Cherry Canyon \#1

0.77

$0.61 \pm$

0.59

Cherry Canyon th

$92.0 \pm 16.6^{\mathrm{Kd}_{\mathrm{Am}}}$

$-2.90 \pm$

4.08

$>700$

127

Culebra

Cherry Canyon \#1

$3.15 \pm$

$20.80 \pm$

$0.76{ }^{K d_{\mathrm{Np}}}$
3.60
$\mathrm{Kd}_{\mathrm{Pa}}$

Culebra

Cherry Canyon \#1

$6.24 \pm \quad 2.68$

$72.07 \pm 66.61$

4. 39 \pm

$42.42+\quad 19.86$

$18.13 \pm \quad 1.08$

Culebra

$$
\mathrm{Kd}_{\mathrm{Pu}}
$$

Cherry Canyon \#1 Not Determined

Not Determined

Not Determined 
Table 15b. Actinide $\mathrm{Kd}$ 's $\left(\mathrm{ml} / \mathrm{m}^{2}\right)$

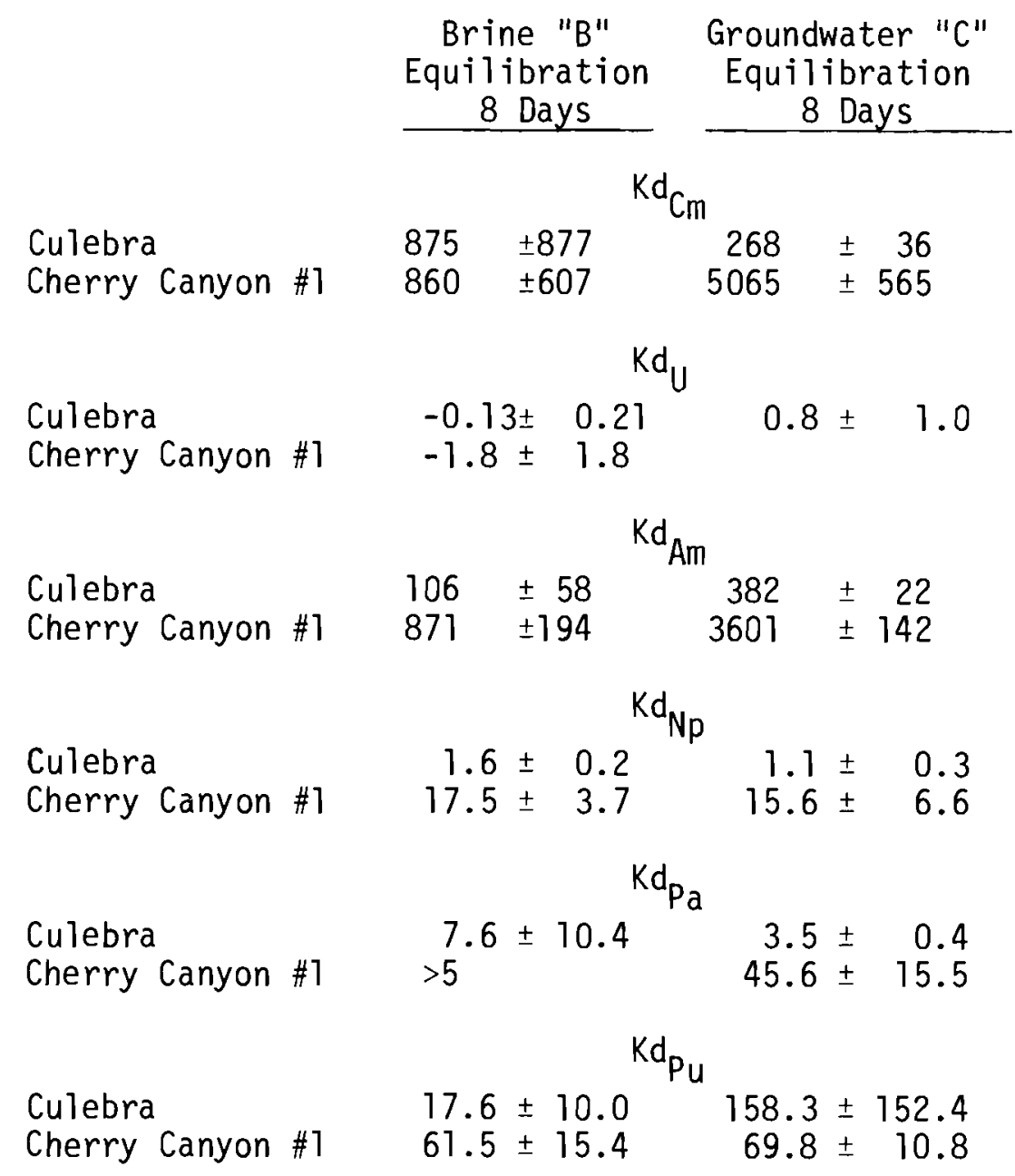


units of $\mathrm{ml} / \mathrm{m}^{2}$ (fracture flow). In a 11 cases the values shown are the averages of triplicate samples and the \pm values represent one standard deviation. Negative values are an artifact of the counting and blank container adsorption corrections and indicate no or very low sorption has occurred.

\section{DISCUSSION}

The $\mathrm{pH}$ of the effluents varied despite the pre-equilibration. The Brines "XA", "XB", and "B" and distilled water were prepared with an initial $\mathrm{pH}$ of 6.5 while the groundwater " $\mathrm{C}$ " $\mathrm{pH}$ was set at 7.5. After each equilibration period a drop of acid or base was added if the system had strayed from the desired $\mathrm{pH}$. With this crude $\mathrm{pH}$ control, the $\mathrm{pH}$ range in Table 16 was found for each solution. Detailed pH results versus rock type and equilibration time are shown in Tables $11 \mathrm{a}-\mathrm{c}$.

Tables 1la-c show a maximum of $0.4 \mathrm{pH}$ units variation for a given solution in contact with various rocks. In most instances the final effluent $\mathrm{pH}$ values for a given solution versus the rocks vary by less than $0.2 \mathrm{pH}$ units. If there is any effect of this slight pH variation in a given solution, it would probably effect Eu, Ce, and the actinides the most. Thus observed differences in Kd's for a given solution probably reflect differences in the rock's affinity for a nuclide rather than effects of solution $\mathrm{pH}$ variations.

Table 16 shows significant pH differences occurred between solutions.

Table 16. Range of pH Found in Effluents

\begin{tabular}{|c|c|c|}
\hline Solution & $\mathrm{pH}$ Range & $\mathrm{pH}$ Average \\
\hline Brine "XA" & $6.03-6.88$ & $6.48 \pm 0.24$ \\
\hline Brine "XB" & $6.60-7.35$ & $6.88 \pm 0.24$ \\
\hline Brine "B" & $6.52-7.67$ & $6.90 \pm 0.43$ \\
\hline Ground Water "C" & $7.39-8.23$ & $7.70 \pm 0.33$ \\
\hline Distilled Water & $7.95-8.68$ & $8.29 \pm 0.17$ \\
\hline
\end{tabular}


Except for Brine "XA" the solutions in general tended towards more alkaline $\mathrm{pH}$ 's than desired. As the rare earth and several of the actinide isotopes may be very sensitive to $\mathrm{pH}$, the differences in observed $\mathrm{Kd}$ 's for a given rock versus the various solutions may reflect some dependency on $\mathrm{pH}$ as well as chemical composition. Thus it will be difficult to relate the differences in $\mathrm{Kd}$ for a given rock entirely to solution composition (competing cation content).

The distilled water dissolved small portions of ions as reported in Table 5 but for further discussion will be designated "distilled water".

The batch $\mathrm{Kd}$ values for the fission products studied in general show much higher sorption will occur in distilled water than the groundwater and salt brines. In all cases except cerium there is significantly more sorption occurring in the distilled water environment. The above data could support a simple ion exchange mechanism wherein the bulk salt solution (containing single and multiply charged ions) competes for available sites and lowers the $\mathrm{Kd} .{ }^{*}$ Even though the groundwater " $\mathrm{C}$ " total salt concentration is only $1 \%$ of the salt brine, the $\mathrm{Kd}_{\mathrm{Sr}}$ is $10 \mathrm{w}$ and the $\mathrm{Kd}_{\mathrm{Cs}}$ is only $4-13 \mathrm{ml} / \mathrm{g}$ compared to distilled water values of 2000-7000 $\mathrm{ml} / \mathrm{g}$. It appears that the sandstones, dolomites, and limestone materials studied retard the movement of alkali metals moderately and alkaline earth metals only slightly if the carrier solution is similar to the groundwater present in the Rustler formation ("C").

Besides this exchange mechanism, especially for the rare earths cerium and europium, the $\mathrm{pH}$ differences of the distilled water and brines ( $\mathrm{pH} 8.0$ to 8.4 vs. 6.0 to 7.2 ) may also contribute to the observed higher sorption. We have observed a large $\mathrm{pH}$ dependence for europium sorption over the range $\mathrm{pH}$ 5-8 and assume cerium would behave in a similar fashion. The rare earth elements can hydrolyze and subsequently precipitate in basic and weakly acidic solutions, such as those used in this study, and have a significant effect on $\mathrm{Kd}$. Mechanisms other than ion exchange which may be of significant importance regarding the distribution of radionuclides among the rock and solution phases include physical sorption and desorption, precipitation 
anionic complexation, oxidation-reduction changes, mineralization or any combination of these. Such complexity makes a totally conclusive interpretation of results obtained quite difficult.

The europium results cannot totally be explained by simple ion exchange theory because Brine "XB", with a lesser salt content and lower proportion of divalent cations, should yield a larger Kd than samples in Brine "XA". Differences in $\mathrm{pH}$ also cannot explain why Brine "XA" results in a larger Kd than Brine "B". As one might expect, the sandstones sorb less europium than the dolomites and limestone. On a surface area basis, limestone sorbs significantly more europium than the other four rock samples.

The antimony results can presumably be explained by ion exchange theory. Antimony in natural waters is usually found as an anionic oxide complex. Since rock materials have a much lower anion exchange capacity than cation exchange capacity, the low $\mathrm{Kd}_{\mathrm{Sb}}$ are understandable. Again, the bulk anion competition of the brines lowers the $\mathrm{Kd}$ from values obtained in distilled water. Sorption of Sb from Brine "XB" is slightly greater than from Brine "XA" which could support the ion exchange mechanism. No rock type appears to sorb significantly more Sb than another.

The technetium results appear to follow the same trends found for antimony. In the natural environment technetium should be found as the anionic complex $\mathrm{TCO}_{4}{ }^{-}$and thus would not be expected to show much sorptive affinity for rocks. The value of 6.70 for $\mathrm{Kd}_{\mathrm{Tc}}$ on 1 imestone (Cherry Canyon \#1) for the groundwater " $C$ " is the highest value that we have observed for Tc. Further studies would be necessary to further elucidate the sorption mechanism.

The ruthenium results also agree with simple ion exchange theory with the Kd being much larger in distilled water than the brines. The most concentrated salt ("XA") yields the lowest Kd as one would expect. The chemistry of ruthenium is also $\mathrm{pH}$ dependent and may be causing part of the larger $\mathrm{Kd}$ value in distilled water. The speciation of ruthenium in nuclear wastes has been shown to be quite complex. Certain unidentified ruthenium species have been shown to be very mobile in carbonate dominated groundwaters 
on the Hanford reservation. It will be quite important to identify the chemical form of ruthenium, as well as that of other radionuclides with multiple oxidation states, released by solidified wastes before an accurate Kd may be determined. Again, the Cherry Canyon limestone sorbed the most $\mathrm{Ru}$ of all the rocks based on surface area calculations.

Over the first two equilibration times the cerium data follow trends predicted by ion exchange and $\mathrm{pH}$ dependent precipitation mechanisms. In the brines, cerium was the fission product most readily sorbed, with (Cherry Canyon \#1) 1 imestone sorbing the most cerium and the two sandstone samples (Cherry Canyon \#2 and \#3) sorbing the least based on surface areas.

The strontium data show a mediocre sorption in distilled water and rather poor sorption in the groundwater and brines. If simple ion exchange theory was controlling the sorption, one might expect the groundwater " $C$ " to show a $\mathrm{Kd}_{\mathrm{Sr}}$ ranking " $\mathrm{C}$ " >>Brine "XB" $\sim$ Brine " $\mathrm{B}$ " > Brine "XA" instead of the observed results which show no significant sorption in any of the four solutions. On a surface area basis the limestone appear to sorb the most Sr from distilled water and groundwater "C", but the brine data show no trends.

The batch $\mathrm{Kd}_{\mathrm{CS}}$ in distilled water is extremely large for all of the rock materials studied and moderate in the groundwater, but $\mathrm{Kd}^{\prime} \mathrm{s}$ in the brine are essentially zero. It doesn't appear that a significant difference in sorption is present between brines "XA", "XB", and "B". The dolomite samples appear to show significantly lower Kds than the limestone and sandstones in distilled water. The cesium component of brines "XA" $(10 \mathrm{mg} / 1)$, "XB" $(10 \mathrm{mg} / 1)$, and "B" (1 mg/1) may have resulted in saturation of selective Cs sorptive sites in the rocks, preventing the bulk of the tracer ${ }^{137}$ Cs from being sorbed. In similar Cs sorption studies to be published by R. G. Dosch at Sandia Laboratories, electron microprobe studies showed that cesium was being selectively sorbed by trace amounts of clay in the Culebra and Magenta rock samples. This type of study may prove useful in interpretating other sorbtion and Kd results.

Five of the seven fission products investigated showed very small sorption kd values with the high surface area crushed rock material used so far. This 
tends to indicate that experimentation with thin rock wafers simulating rock fractures may not be of great benefit or of high priority at the moment. However, radionuclide sorptive behavior with solution contact of actual rock fractures, aged, weathered and possibly coated with clays, may yield significantly different results. This may not be an easy, repeatable, or reliable experiment to perform. Experiments determining the sorptive capacity of solid rocks (columns) in contact with radionuclides in solution may provide a more realistic simulation of transport behavior in an actual repository, more realistic than batch $\mathrm{Kd}$ experiments on crushed rocks. Such experiments may be considered as a second generation of radionuclide migration experiments, expanding upon the data presented here. Such experiments are planned or in progress at other laboratories.

The actinide Kd's show extremely high sorption (>1000 $\mathrm{ml} / \mathrm{g}$ ) occuring for curium and americium, good sorption (>100 $\mathrm{ml} / \mathrm{g}$ ) for plutonium and fair sorption for protactinium and neptunium. Uranium was only poorly sorbed by the crushed rock materials.

There appears to be a significant difference in $\mathrm{Kd}$ between the salt brine and groundwater solutions for only the americium and plutonium data. These results might lead one to conclude that simple ion exchange theory does not describe the observed sorption of trace actinides. The results for the fission products based on only the two solutions Brine "B" and groundwater " $C$ " did not show much sensitivity to solution ionic strength, either therefore more experiments with several solutions at variable ionic strengths need to be run to identify whether trace actinide sorption is significantly affected by cation ion exchange. More than likely, the effects of oxidation-reduction chemical behavior in solution, hydrolysis, precipitation, and anionic complexation have a significant effect on the determined actinide $\mathrm{Kd}$ values.

The curium data for the 5 and 8 day equilibration periods show a wide variation which may have been caused by the decrease in $\mathrm{pH}$ between the two equilibration times. There is evidence that curium hydrolysis can occur which might decrease the sorption as $\mathrm{Cm}(\mathrm{OH})_{3}$ precipitate redissolves. The 
extremely high Kd and apparent lack of sensitivity to solution ionic strength leads us to believe that mechanisms other than ion exchange are controlling the fate of curium.

The high Am sorption and apparent sensitivity to salt content substantiate the belief that trace Am in solution would be present as $\mathrm{Am}^{+3}$ free ions.

Although the $\mathrm{Pu}$ data are meager, it appears that $\mathrm{Pu}$ in trace concentrations will sorb and migrate much slower than the carrier water. The observed dependence on solution salt composition may be caused by $\mathrm{Pu}^{+4}$ being present and competing with other cations for available exchange sites.

The protactinium data is presented because enough ${ }^{233} \mathrm{~Pa}$ daughter product of ${ }^{237} \mathrm{~Np}$ was present to analyze. Very little migration behavior information is available on $\mathrm{Pa}$; it is not considered a long term environmental problem.

The neptunium data show moderate sorption which lends credence to theoretical data which identifies $\mathrm{NpO}_{2}{ }^{+}$as the predominate species present in neutral groundwaters. Although other actinides with high positive charges sorb to a greater extent, Np still shows more tendency to sorb than Sr and Cs, especially from salt brines.

Uranium was observed to sorb very poorly; however, the fact that the tracer concentration used was rather high (3-8 ppm) and the rocks have low exchange capacities could be biasing the results (similar to the results discussed for $(\mathrm{S})$. The rocks may have become saturated wi thout needing much of the $U$ mass in solution, thus leaving the bulk of uranium in solution. Future experiments at much lower $U$ concentrations should be run. This will necessitate chemical separations and alpha counting or chemical analysis. The results obtained do support the trends observed in natural weathering sequences that $\mathrm{U}^{+6}$ as $\mathrm{UO}_{2}^{+2}$ is mobile. Therefore, the low $\mathrm{Kd}$ 's may be correct if $\mathrm{U}^{+6}$ should be the predominant species present in these experiments. 
In all cases, the effects of container adsorption and simple precipitation from carrier solutions have been removed from the $\mathrm{Kd}$ data presented. The measured values should reflect the interation and removal caused by the geologic media contacting the radionuclide containing leachant solution. If the container sorption and precipitation (upon ageing or solution $\mathrm{pH}$ change) are not removed, the $\mathrm{Kd}$ 's of the rare earths, Ru and the actinides would appear larger. Care must be taken not to over-estimate $\mathrm{Kd}$ 's for these complex nuclides.

The percentage of the initial spike remaining in solution for the blank samples are shown in Table 17. The Sr, Cs, and Sb remained in solution throughout the experiment. Very little precipitation or container adsorption occurred with these three isotopes.

The amount of Ru remaining in solution was constant with time for each solution, but the percentage varied with each solution. From past experience, container adsorption of $\mathrm{Ru}$ has been a recognized problem. If the loss in Ru connotes container adsorption the kinetics are rapid. The distilled water solution with the higher $\mathrm{pH}$ and no competing ions lost the most Ru. It is impossible to separate container adsorption effects from possible $\mathrm{pH}$ effects.

The Ce data show a continual decrease in the percentage of original spike remaining in solution with time for all systems. The distilled water sample showed an almost quantitative loss of Ce. Precipitation and container sorption again are the probable causes.

A significant portion of the Eu spiked into the samples was removed from the blank solutions. For salt solutions "XA" and "XB" the decrease continued with time. Unlike the Ce, the distilled water solution lost less Eu than one of the Brines ("XB"). Direct $\mathrm{pH}$ and container sorption trends were not recognizable. For $S b, S r$, and $C s$, which remain in solution in the blanks, the Kd values versus time show no trends. The Kd values after 4 to 7 days were about the same as after 47 days equilibration.

The $\mathrm{Kd}_{\mathrm{Ru}}$ values appear to increase at each equilibration time. One hypothesis is slow "physical" sorption onto the rock material as opposed to more rapid chemical sorption. 
Table 17. \% of Isotope Remaining in Blank Supernate

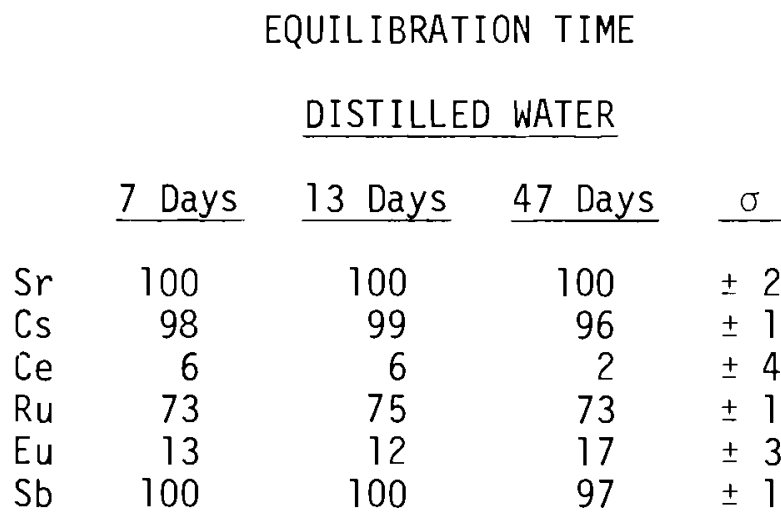

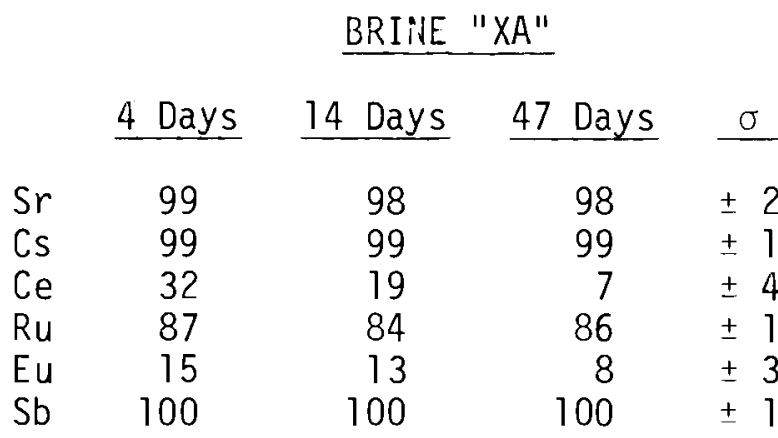

BRINE "XB"

5 Days 13 Days 40 Days $\sigma$

$\begin{array}{rrrrr}\mathrm{Sr} & 100 & 96 & 100 & \pm 2 \\ \mathrm{Cs} & 97 & 99 & 100 & \pm 1 \\ \mathrm{Ce} & 62 & 53 & 17 & \pm 3 \\ \mathrm{Ru} & 94 & 92 & 91 & \pm 1 \\ \mathrm{Eu} & 9 & 6 & 5 & \pm 4 \\ \mathrm{Sb} & 99 & 100 & 100 & \pm 1\end{array}$


The apparent decrease in Ce sorption at the 40-47 equilibration period reflects the loss of $\mathrm{Ce}$ in the blanks used for influent concentrations in the calculations. The influent count rates dropped dramatically, while the effluent count rates remained quite low because of rock sorption, and the mathematical calculations based on count rate differences decreased. Thus the apparent drop in $\mathrm{Kd}$ in an artifact of the experimental design rather than Ce remobilization.

The large increase in $\mathrm{Kd}_{\mathrm{Eu}}$ in distilled water at 47 days equilibration was caused presumably by the observed increase in Eu concentration in the blank at 47 days. This increase is probably spurious, caused by resuspension of fine hydroxide precipitates (colloids) after centrifugation and before sampling. The difference in count rates between effluents and the blank influent was thus made artificially high and resulted in erroneously high Kd values. Excepting the time dependence of $\mathrm{Kd}_{\mathrm{Ru}}$, the other fission product nuclides appear to yield a stable value after 4-7 days equilibration.

Preliminary experiments with the actinides showed considerable precipitation of spikes as the solution pH was adjusted to the desired value of 6.5 or 7.5. For these experiments, the amount of spike added to solutions was calculated to be less than the solubility product at a given $\mathrm{pH}$. Therefore, precipitation should have been minimal. The $\mathrm{Np}, \mathrm{Am}, \mathrm{Cm}$, and $U$ blank samples did not show any loss of count rate between the fifth and eight day of equilibration. As the experiments were not continued to longer times, a full assessment of container adsorption and precipitation cannot be performed. The time dependence of actinide $\mathrm{Kd}$ 's cannot be adequately addressed from the data presented herein. No significant changes in $U, C m$, $\mathrm{Am}$, and $\mathrm{Np}$ data at 5 and 8 days were evident.

\section{SUMMARY}

Preliminary $\mathrm{Kd}$ values for the isotopes of $\mathrm{Sr}, \mathrm{Tc}, \mathrm{Ru}, \mathrm{Sb}, \mathrm{Cs}, \mathrm{Ce}, \mathrm{Eu}$, $\mathrm{Pa}, \mathrm{U}, \mathrm{Np}, \mathrm{Pu}, \mathrm{Am}$, and $\mathrm{Cm}$ were obtained for solutions and rock types specific to the existing subsurface environment at the Waste Isolation Pilot Plant site in southeastern New Mexico. The values were obtained by the batch method on freshly crushed material in contact with solution. Data was 
reported in units of both $\mathrm{ml} / \mathrm{g}$ and $\mathrm{ml} / \mathrm{m}^{2}$ to allow migration rate calculations assuming either porous or fracture flow. The solutions utilized represent salt brine, groundwater and distilled water. The rocks studied included two dolomites, two feldspar sandstones, and a limestone.

In general, sorption of $\mathrm{Sr}, \mathrm{Tc}, \mathrm{Ru}, \mathrm{Sb}, \mathrm{Cs}$, and $\mathrm{U}$ on crushed rock materials was poor $(<5 \mathrm{ml} / \mathrm{g})$ in brine solutions. The sorption of rare earths (Eu, Ce) and actinides ( $\mathrm{Pa}, \mathrm{Np}, \mathrm{Pu}, \mathrm{Am}$, and $\mathrm{Cm}$ ) was significantly higher even though the cation competition in the concentrated brines would be intense and the sorption capacity of the materials studied is believed to be very low.

Crushed rock materials in contact with groundwater "C" (which had an ionic salt concentration 25 times greater than the equilibrated "distilled" water) showed poor sorption of $\mathrm{Sr}$ and low sorption for Cs. Rock material in contact with distilled water (containing about 2 meq/1 of ions at equilibrium) sorbed $\mathrm{Sr}, \mathrm{Ru}, \mathrm{Cs}, \mathrm{Ce}$, and Eu fairly well, with measured Kd values being in the range of 20-1000 $\mathrm{ml} / \mathrm{g}$. If $\mathrm{Pu}, \mathrm{Np}$, Am, and $\mathrm{Pa}$ distilled water solutions had been contacted with rock, Kd values would probably also have been of this magnitude, or higher.

More work should be performed at intermediate ionic strengths between the distilled water and salt brine concentrations to fully assess the effects of competing ions.

The data for actinides are few and must be considered provisional. More work with actinides in geologically realistic solutions contacting site specific and other appropriate rock types should be performed.

In order to assess whether the retardation afforded by the rocks studied is adequate to prevent hazards to man, water velocities, waste leach rates, time periods to reach the biosphere and specific mechanisms of radionuclide transport and retardation must be determined. The observed results should be used to identify which radionuclides may be most critical and should be emphasized in future studies. 


\section{RECOMMENDATIONS}

1. The Kd data for actinides presented in this document and available in the literature are sparse. More data should be collected on the actinides before attempts are made to adequately perform safety assessment analyses.

Similar studies on actinides are being conducted and planned at Sandia Laboratories (R. G. Dosch) and in programs managed by Battelle Pacific Northwest (R. J. Serne), (Waste Isolation Safety Assessment Program) for the Office of Waste Isolation (Union CArbide, Oak Ridge, Tennessee).

2. A11 the experiments performed in this document investigate nuclide sorption only. As the $\mathrm{Kd}$ used in the safety assessment analysis is assumed to be reversible by the nature of the mathematical treatment, experiments to study desorption should be performed. Many of the nuclides may desorb at a slower rate or not at a11 which would increase the overall retardation substantially and would reduce potential hazards. The mathematical coupled water transport-sorption equations for nuclides which are not strictly reversible will need to be changed to include a Kd sorption and $\mathrm{Kd}_{\Lambda}^{\mathrm{dc}}$ sorption.

3. Migration studies through intact porous cores and through fractured cores should be performed to verify or support migration rates based on batch experiments. A proposed waste repository geology will resemble solid and fractured rock material much more than it will resemble crushed rock. Again, such experiments are planned or in progress. Batch Kd measurements are quite valuable, however, to get initial data and trends of sorption behavior in a limited time period and via relatively simple laboratory procedures.

4. Elements of major significance in waste management which have multiple oxidation states, such as $\mathrm{Pu}, \mathrm{Np}$, and $\mathrm{U}$, etc. need to be investigated in much more detail. Their potential migration/sorption behavior should be measured at the Eh expected in situ in a repository. Experiments should determine: what oxidation state does an element have when 
leached from the waste matrix; what is the migration/sorption behavior of this particular ion; and can the ion change its oxidation state as it migrates.

5. All important waste radionuclides, not just those having multiple oxidation states, should be investigated to determine effects of temperature; radiolytic effects on solution chemistry and resultant effects on migration/sorption; anionic complexes formed in solution; secondary barriers or getters to retard migration; etc. There is obviously a lot of experimentation to be performed; the results reported in this study are only a small, but valuable portion of that total.

6. The extrapolation of short-term laboratory Kd data to the thousand to million year time frame under consideration should be addressed. To date all known slow reactions such as mineral and amorphous coating formation should decrease the mobility of trace constituents but more studies on time extrapolation are needed. 


\section{REFERENCES}

1. Inoue, Y. and W. J. Kaufman. "Studies of Injection Disposal" USAEC Rep TID 7628, pp. 303-323, in Ground Disposal of Radioactive Wastes, 2nd Conference Proceedings (Chalk River Canada, 26-29, September 1961. Compiled and Edited by J. M. Morgan et al., March 1962.

2. Levy, H. B. "On Evaluating the Hazards of Groundwater Contamination by Radioactivity from an Underground Nuclear Explosion" Lawrence Livermore Report UCRL-51278, 1972.

3. Ahlstrom, S. W., H. P. Foote, R. C. Arnett, C. R. Cole, and R. J. Serne "Multicomponent Mass Transport Model: Theory and Numerical Implementation (Discrete-Parcel-Random-Walk Version), BNWL-2127, May 1977.

4. Duguid, J. 0. and M. Reeves. "Material Transport through Porous Media A finite Element Galerkin Model" ORNL 4928, 1976.

5. Bower, C. A. and J. 0. Goertzen. "Surface Areas of Soil and Clays by An Equilibrium Ethylene Glycol Method," Soil Science, Vol. 87, No. 5, pp. 289-292, 1959.

6. Serne, R. J., R. C. Routson and D. A. Cochran. "Experimental Methods for Obtaining PERCOL Model Input and Verification Data," USAEC Report BNWL-1721, 1974.

7. Nowak, E. J. Sandia Laboratories, personal communication, 1977.

8. Bradley, D. J. Battelle Pacific Northwest Laboratories, unpublished data, 1976-77.

9. Fried, S., A. M. Friedman, and J. J. Hines. "The Migration of Plutonium and Americium in the Lithosphere." ANL-76-127, 1976.

10. Cohen, D. "Neptunium Chemistry and Radioactive Waste Management." Presented at 174th American Chemical Society National Meeting, Chicago, August 29, 1977

11. Rai, D. and R. J. Serne. "Adsorption of Pu(IV) and Pu(VI) Under Controlled pH and Eh by Soil Minerals" in preparation, 1977.

12. Rai, Dhanpat and R. J. Serne. "Plutonium Activities in Soil Solutions and the Stability and Formation of Selected Plutonium Minerals," J. of Environmental Quality, Vol. 6, No. 1, pp. 89-95, 1977.

13. Ames, L. L., D. Rai and R. J. Serne. "A Review of Actinide-Sediment Reactions with an Annotated Bibliography," BNWL-1983, BattelleNorthwest, Richland, WA 99352, 1976. 
14. Dosch, R. G., Sandia Laboratories, to be published.

15. Serne, R. J. "Program Plan Task 5 Collection and Generation of Transport Data for the Waste Isolation Safety Assessment Program (WISAP)", Battelle Pacific Northwest Laboratories, 1977. 


\section{ACKNOWLEDGEMENTS}

This work was sponsored by the Energy Research and Development Administration, Division of Fuel Cycle and Production, and funded by the Waste Isolation Pilot Plant (WIPP) program managed by Sandia Laboratories, Albuquerque, New Mexico.

The authors wish to acknowledge the following Sandia Laboratories personnel who provided samples, solution formulations, background information, guidance and most of the funds to perform the experiments: L. R. Hil1, G. E. Barr, D. W. Powers, and S. J. Lambert.

The authors wish to acknowledge J. E. Ratledge (Oak Ridge National Labs) and A. Friedman (Argonne National Lab) who provided several of the actinide isotopes utilized in the study.

The authors wish to acknowledge the following Battelle Pacific Northwest Lab personnel for the efforts mentioned:

D. H. Parks Optical Photography

L. L. Ames X-ray Diffraction

C. W. Thomas Gamma Spectroscopy Instrumentation and Help with its

J. G. Pratt Usage

J. L. Goodrich

N. C. Painter

Typing of Drafts and Final Manuscript. 



\section{APPENDIX A}

OPTICAL PHOTOGRAPHS OF ROCK SAMPLES 


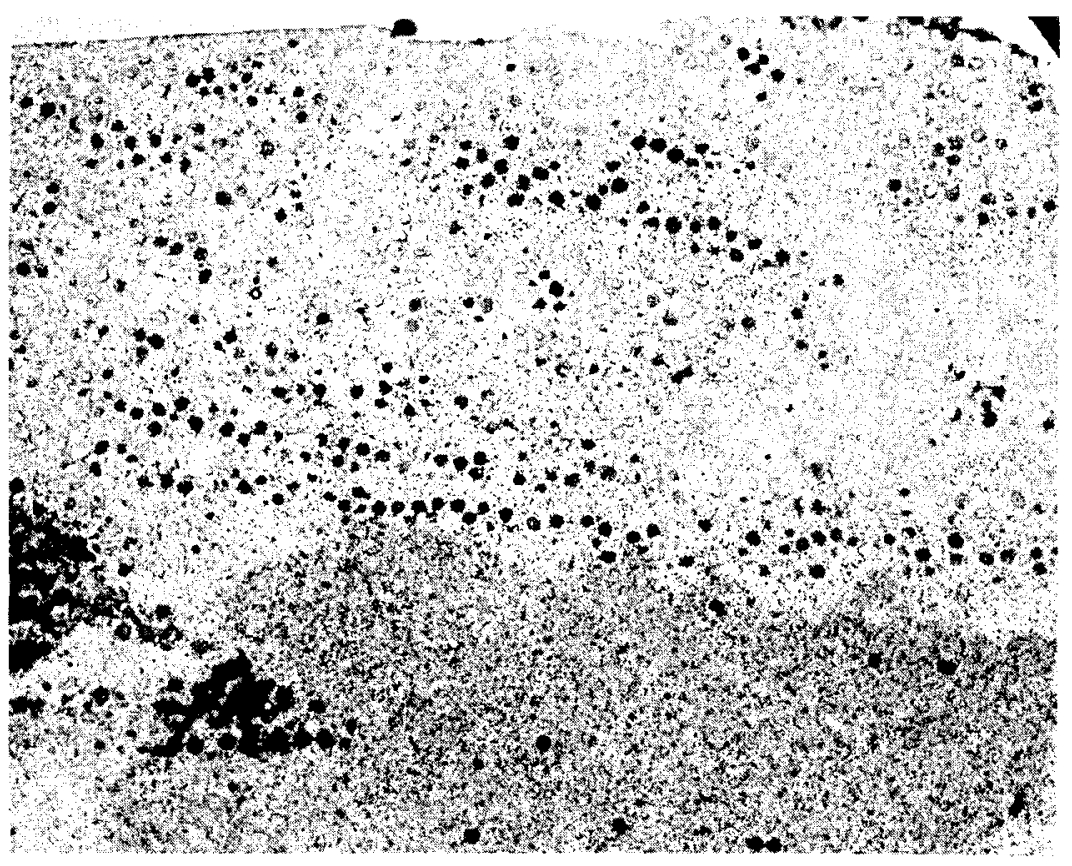

\author{
Magenta - Longitudinal - 8X \\ Negative \#4L585A
}

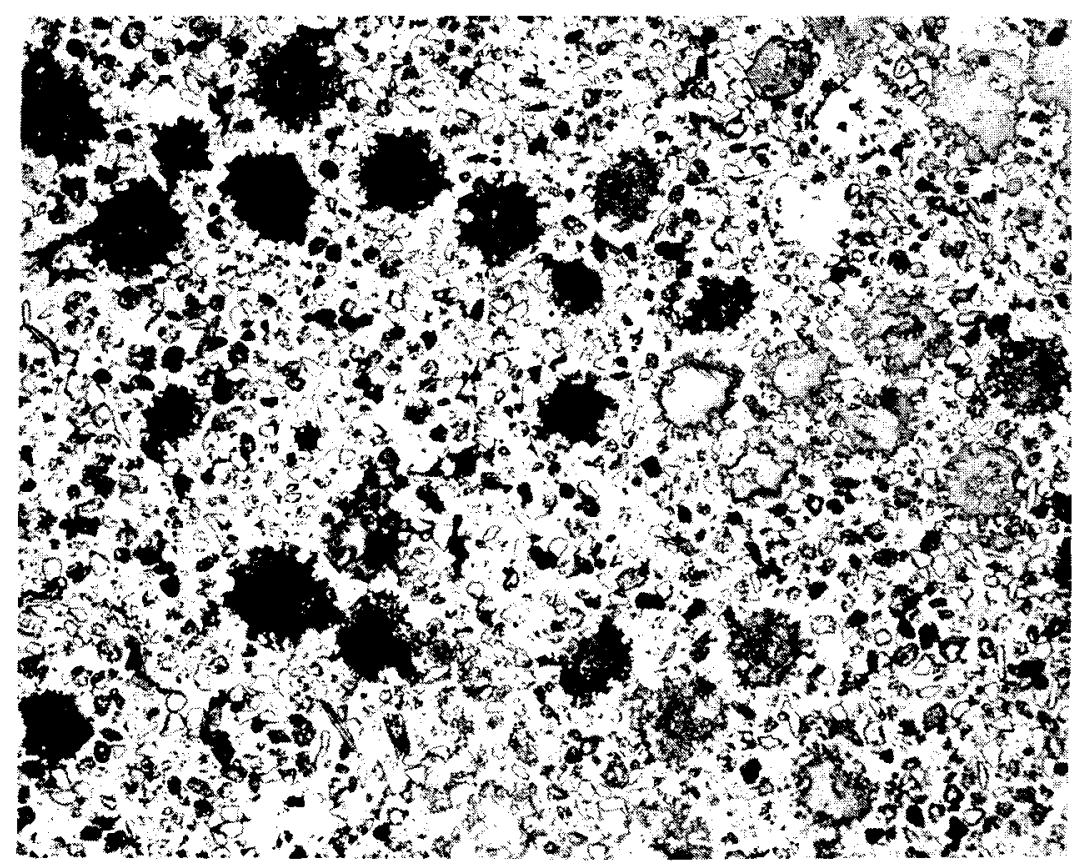

\footnotetext{
Magenta - Longitudinal - 50X

Negative \#4L585B
} 


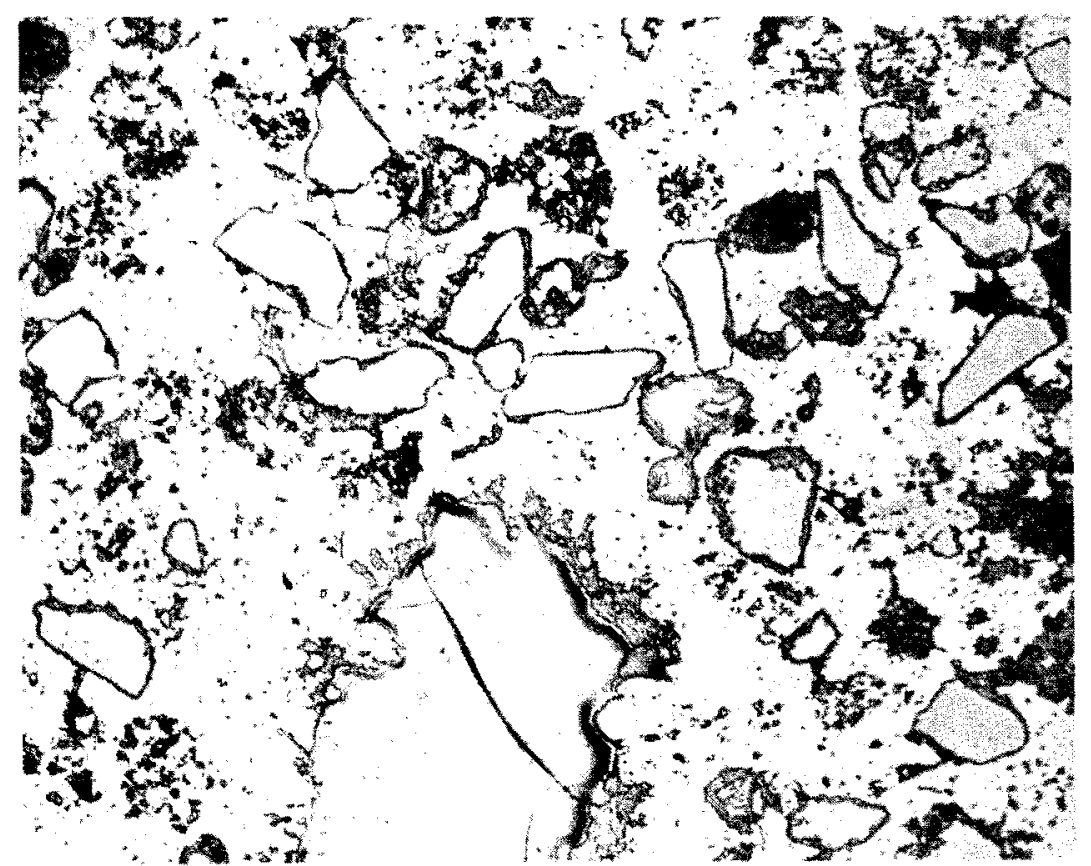

\author{
Magenta - Longitudinal - 250x \\ Negative \#4L585C
}

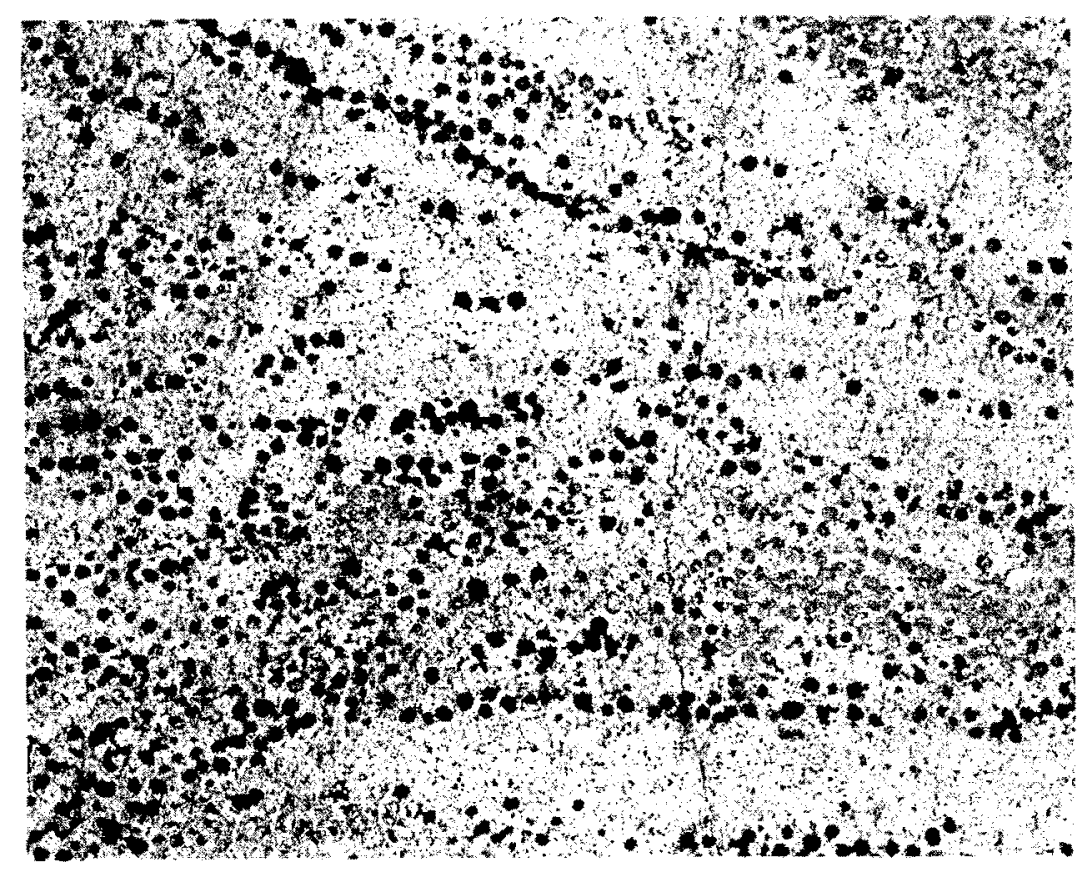

Magenta - Transverse - $8 \mathrm{X}$
Negative $\# 4 \mathrm{~L} 586 \mathrm{~A}$ 


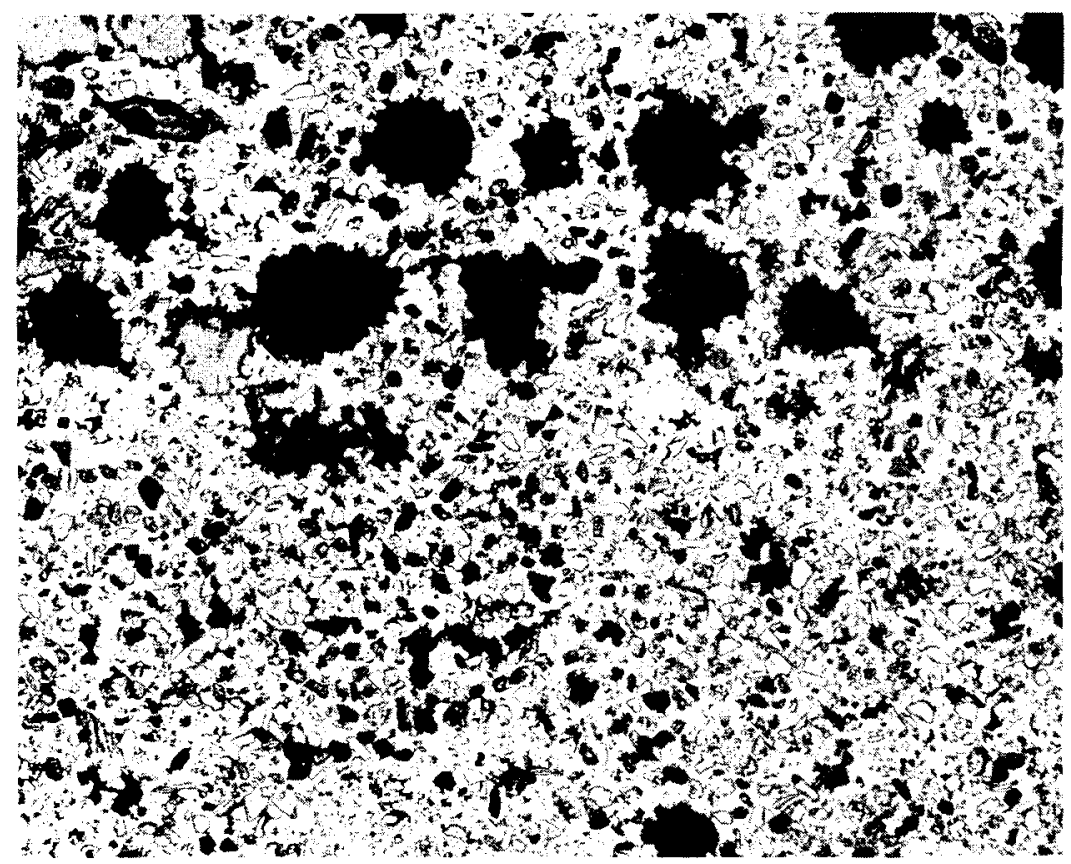

Magenta - Transverse - 50X
Negative \#4L586B

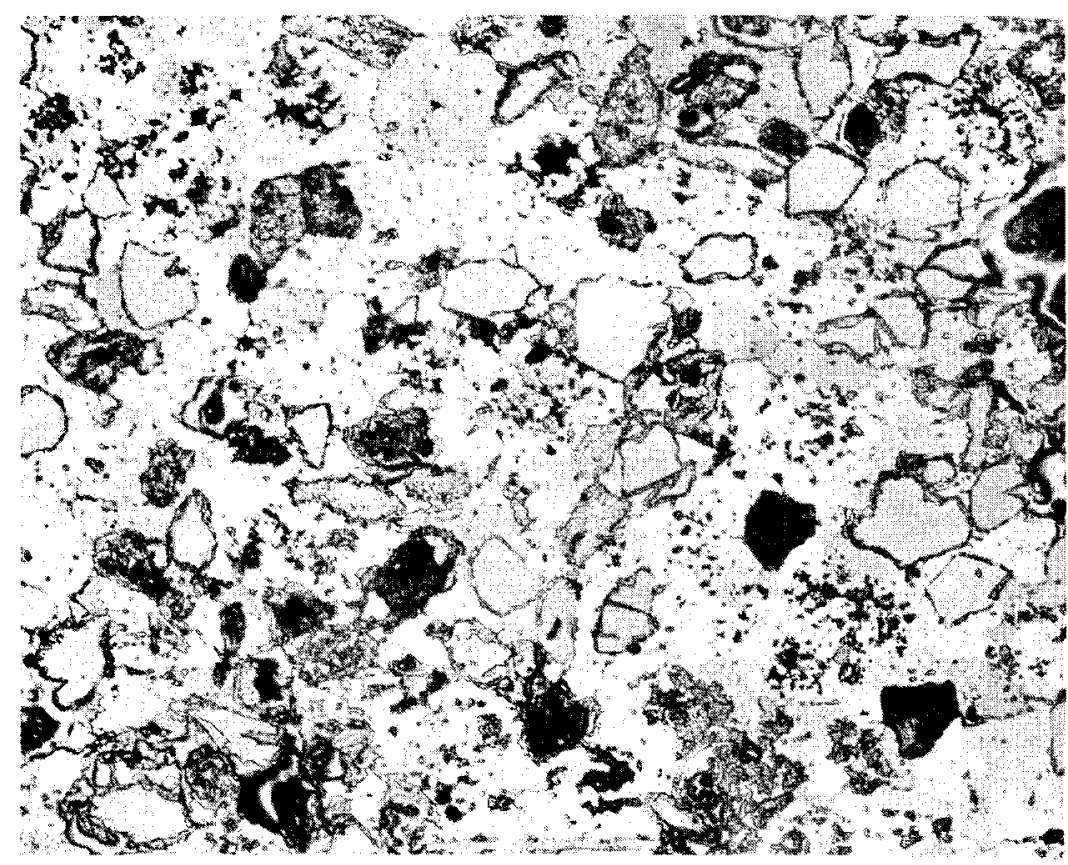

Magenta - Transverse - 250X

Negative \#4L586C 


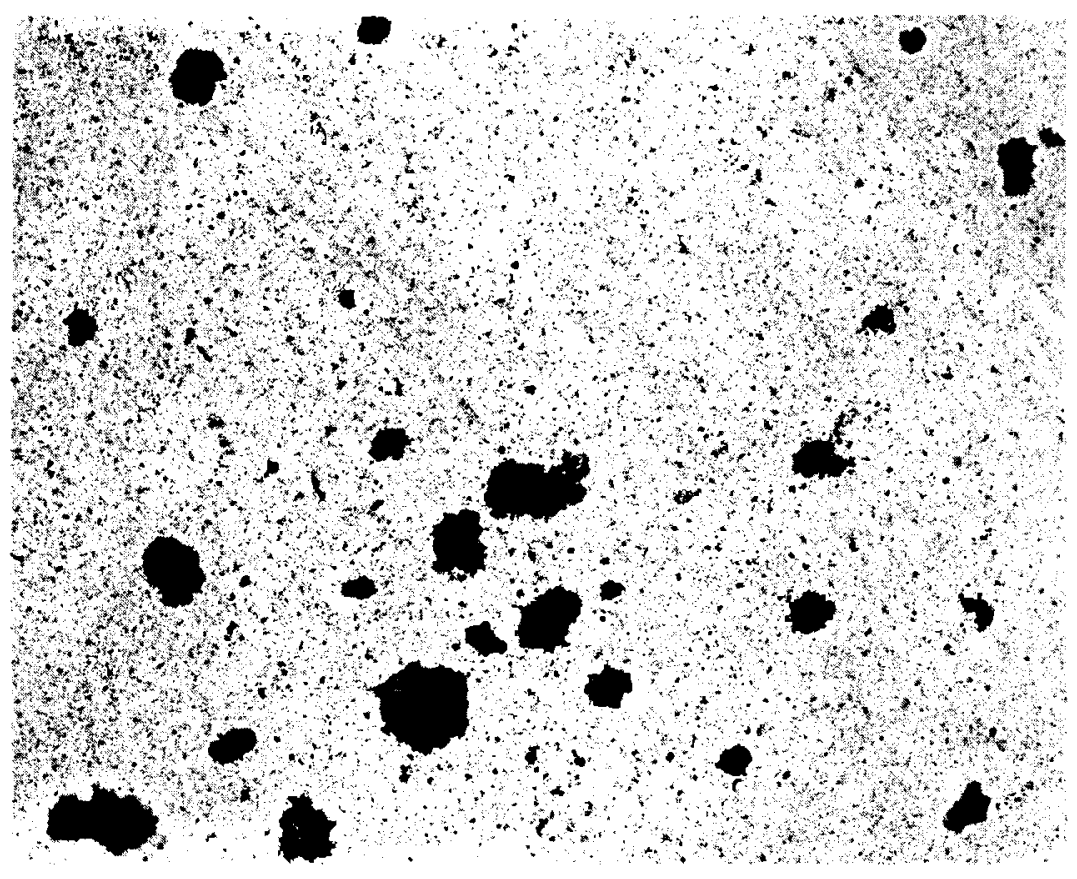

Culebra - Longitudinal - $8 \mathrm{X}$ Negative \#4L587A

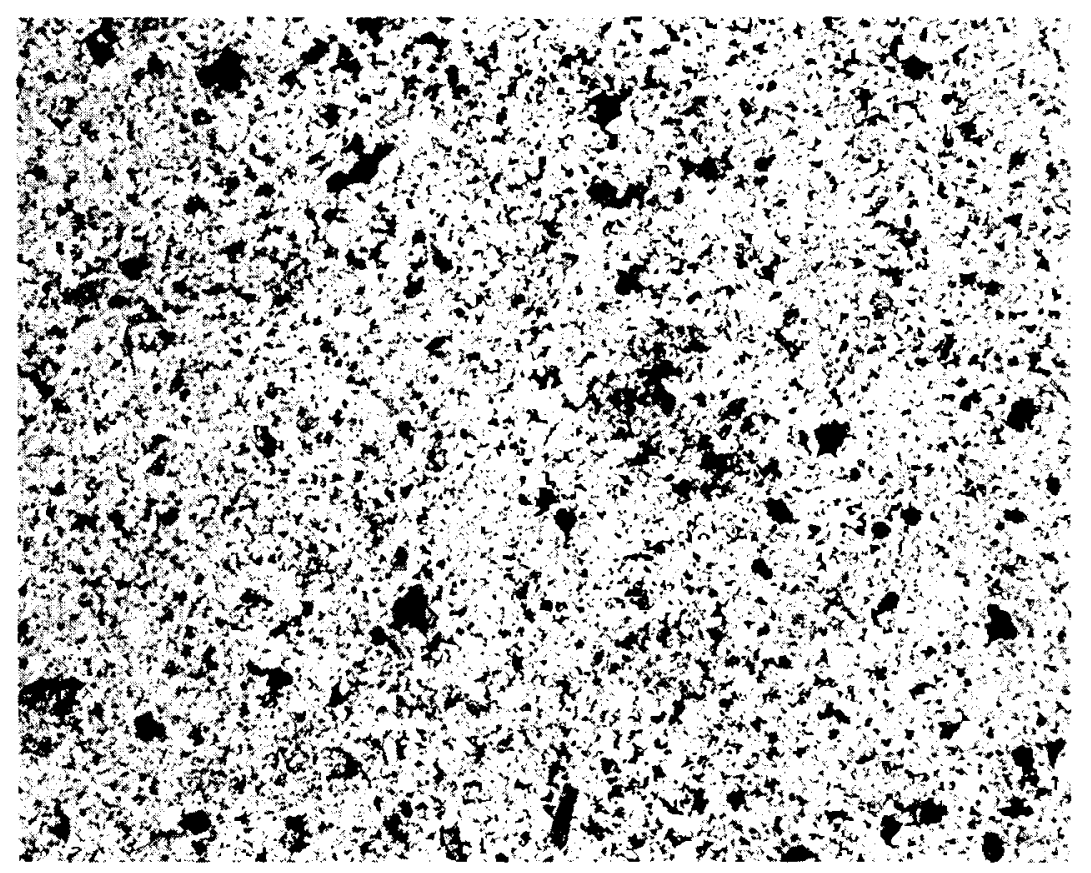

\author{
Culebra - Longitudinal - 50X \\ Negative \#4L587B
}




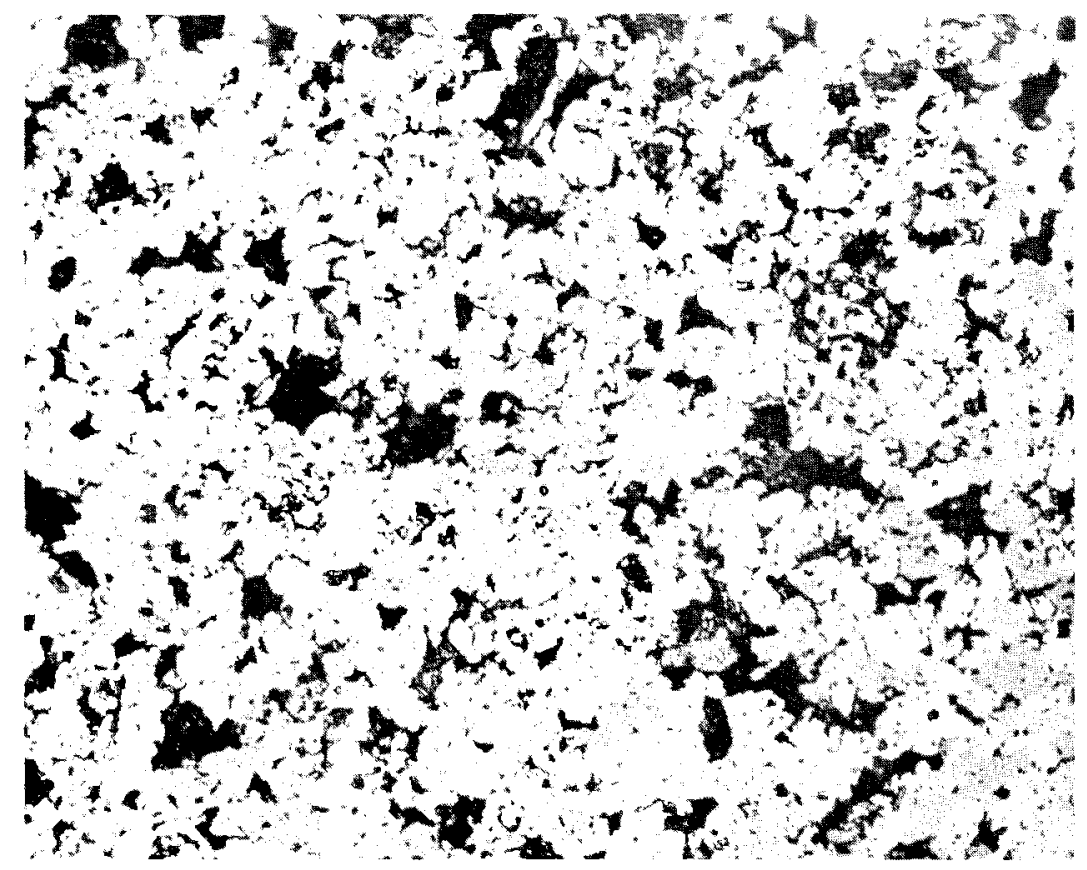

$$
\begin{aligned}
& \text { Culebra - Longitudinal - } 250 \mathrm{X} \\
& \text { Negative \#4L587C }
\end{aligned}
$$

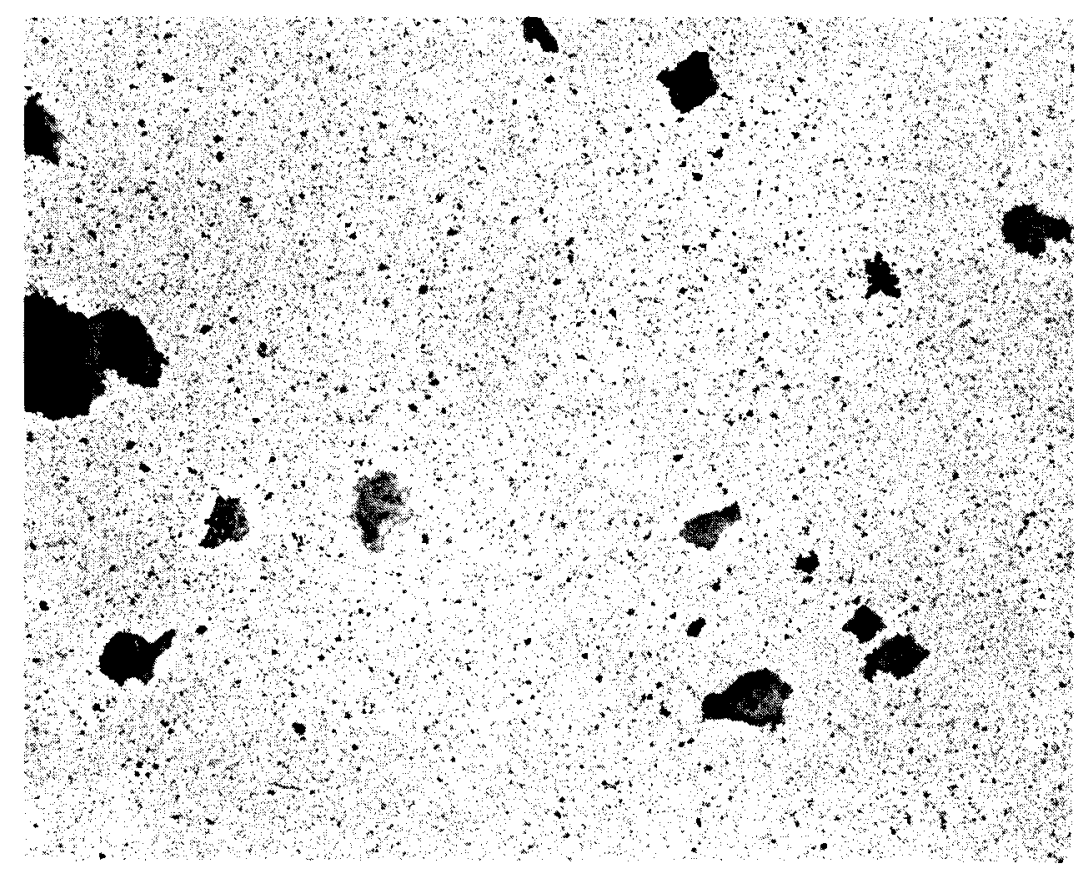

\footnotetext{
Culebra - Transverse - 8X Negative \#4L588A
} 


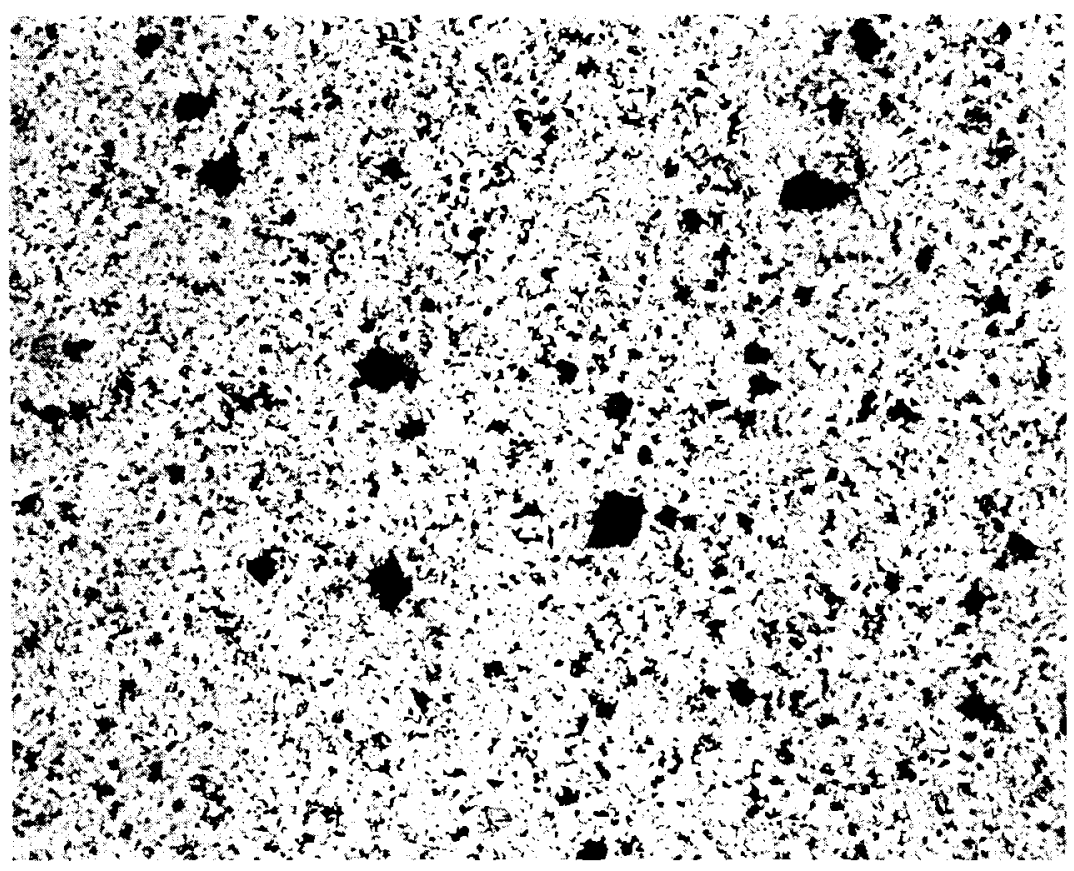

Culebra - Transverse - 50X

Negative \#4L588B

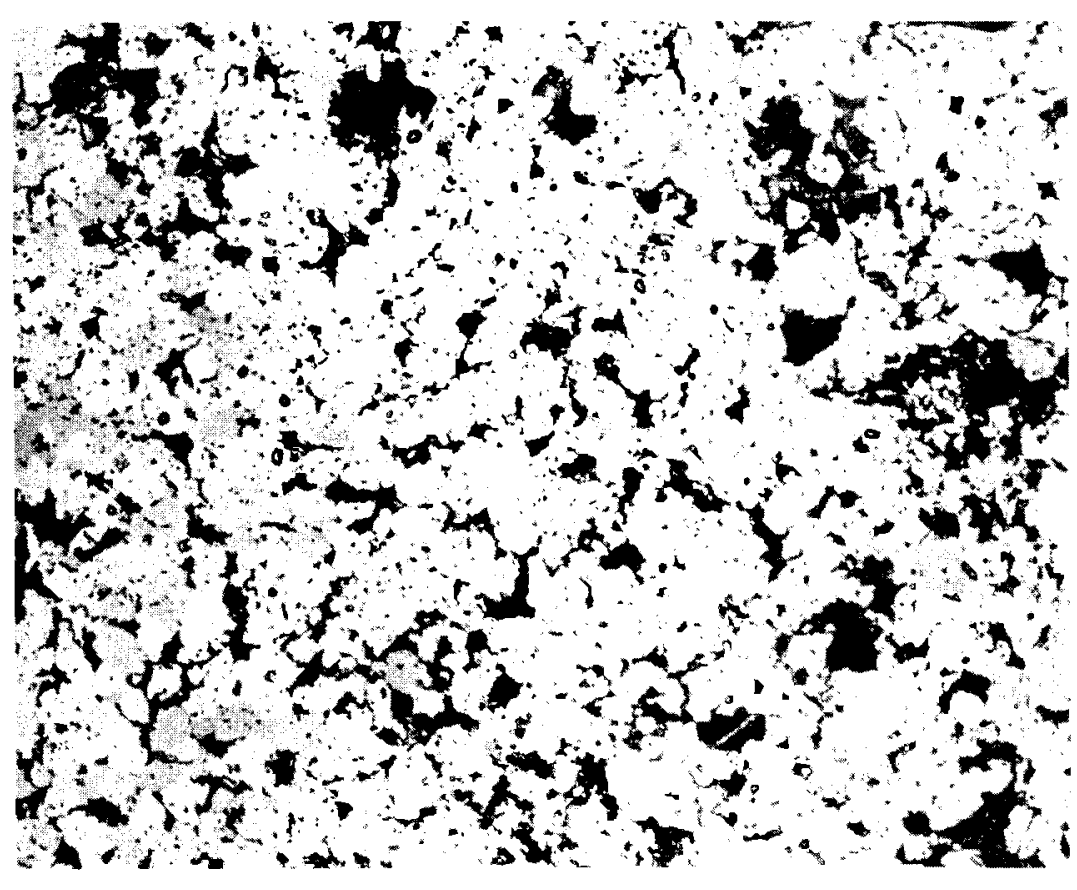

Culebra - Transverse - 250X

Negative \#4L588C 


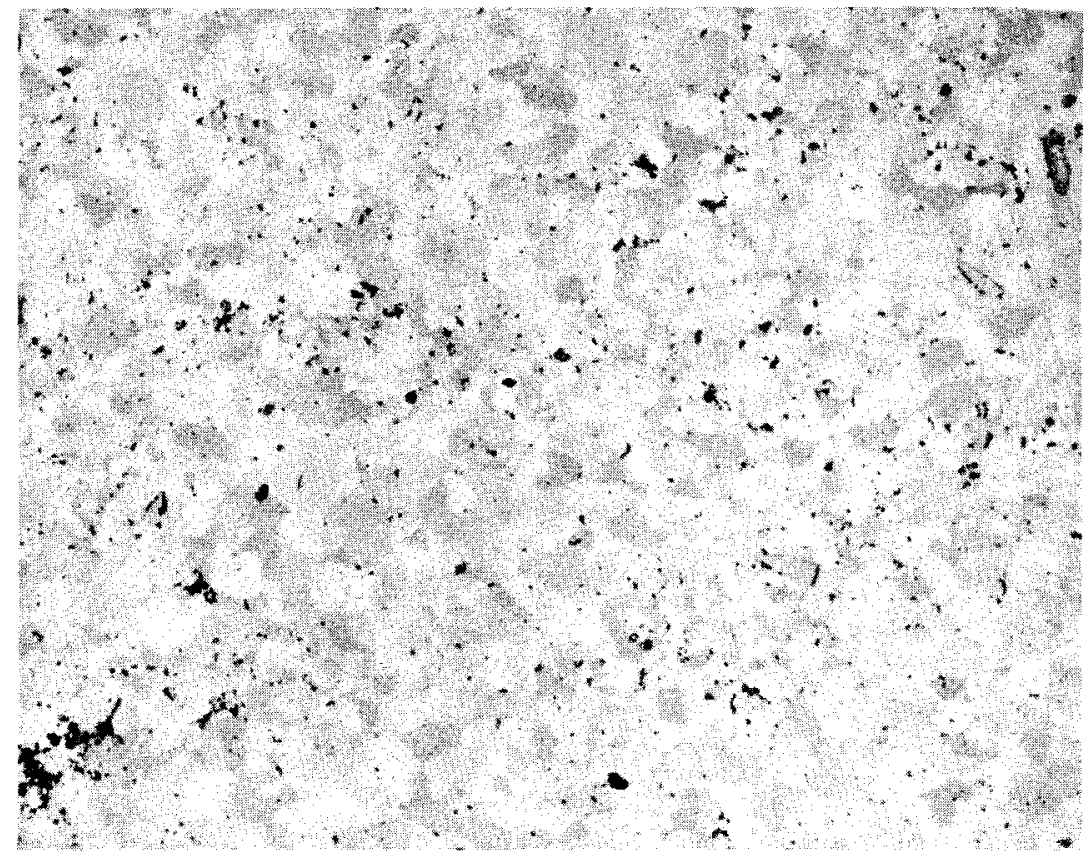

\section{\#l-Limestone - Longitudinal - $250 \mathrm{X}$ Negative \#4L1164A}

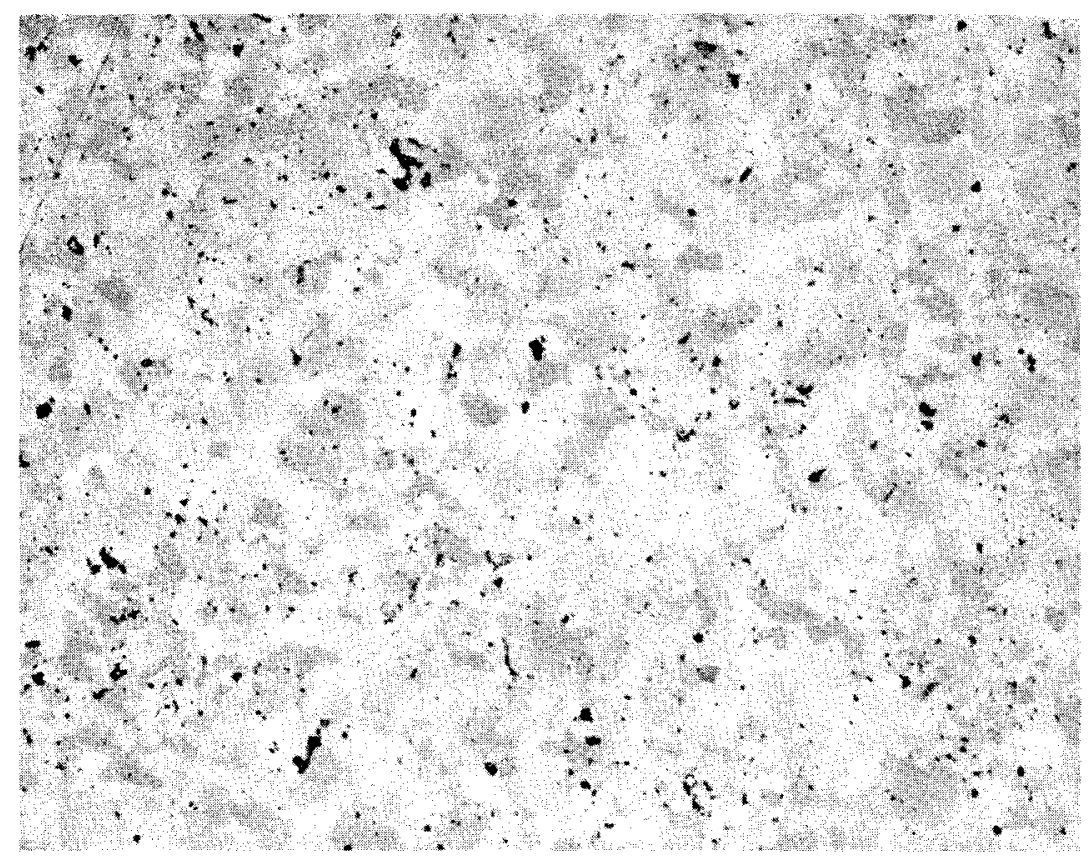

$$
\begin{gathered}
\# 1-L i m e s t o n e-\text { Longitudinal - } 250 \mathrm{X} \\
\text { Negative \#4Ll164B }
\end{gathered}
$$




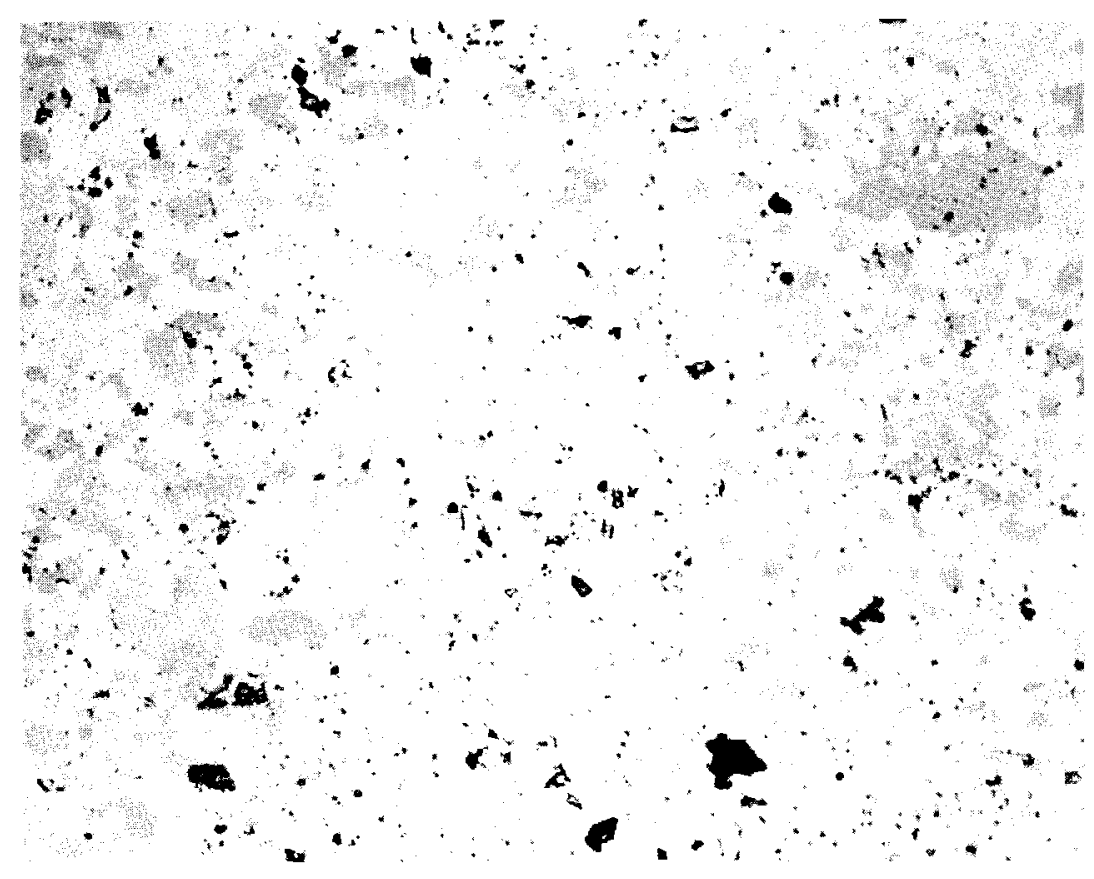

$$
\begin{gathered}
\text { \#1-Limestone - Longitudinal - } 250 \mathrm{X} \\
\text { Negative \#4L1164C }
\end{gathered}
$$

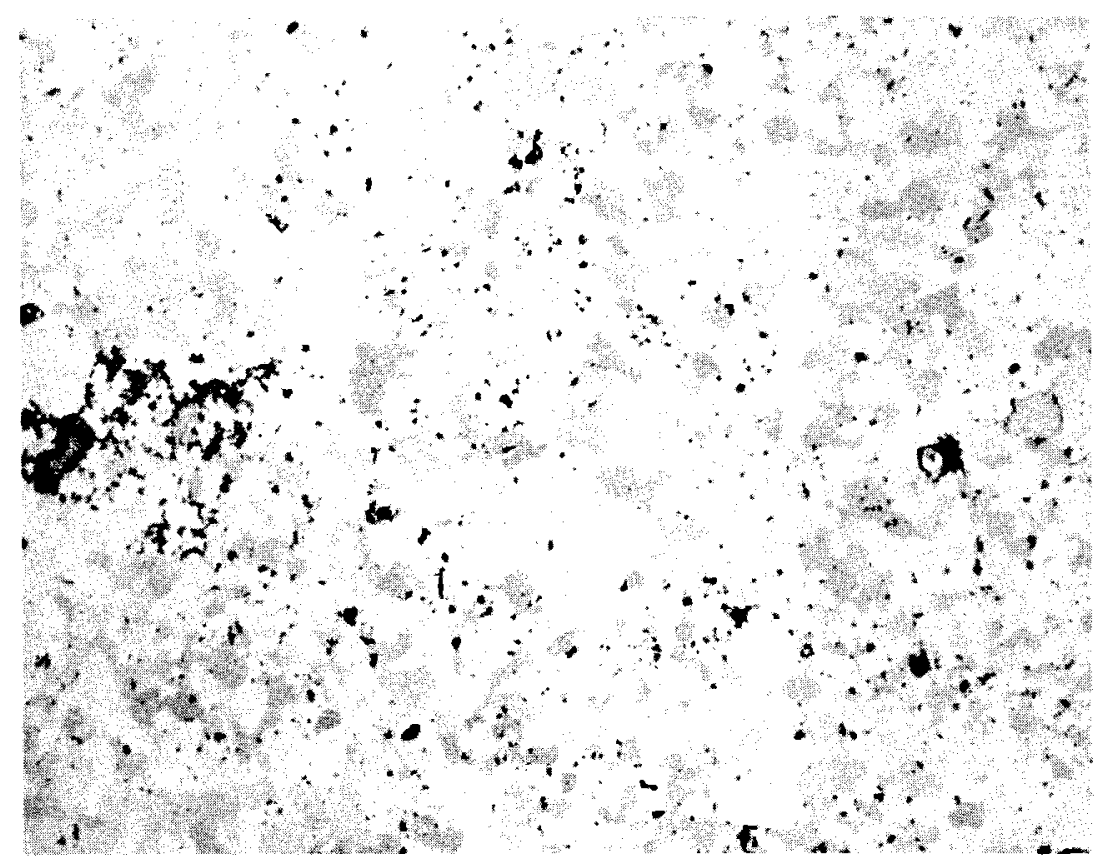

$$
\begin{gathered}
\text { \#1-Limestone - Logitudinal - 250X } \\
\text { Negative \#4L1164D }
\end{gathered}
$$




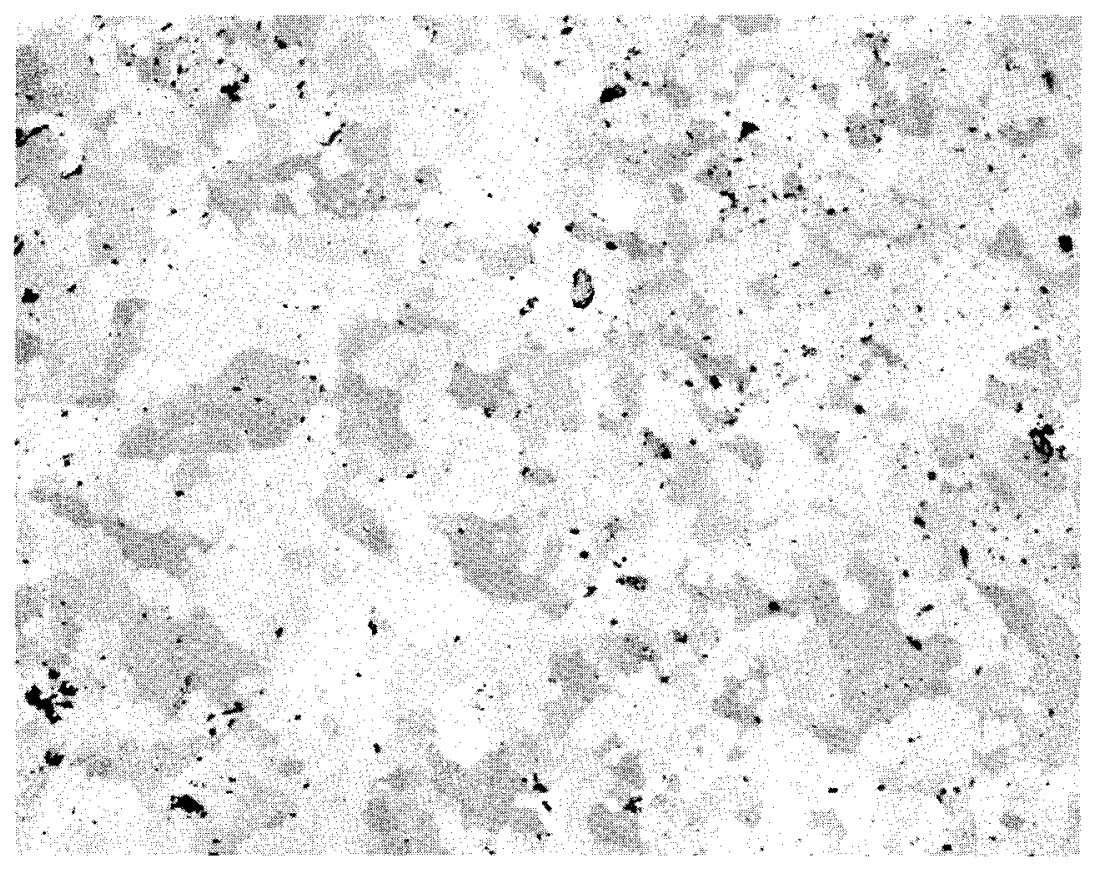

\section{\#1-Limestone - Transverse - 250X Negative \#4L1165A}

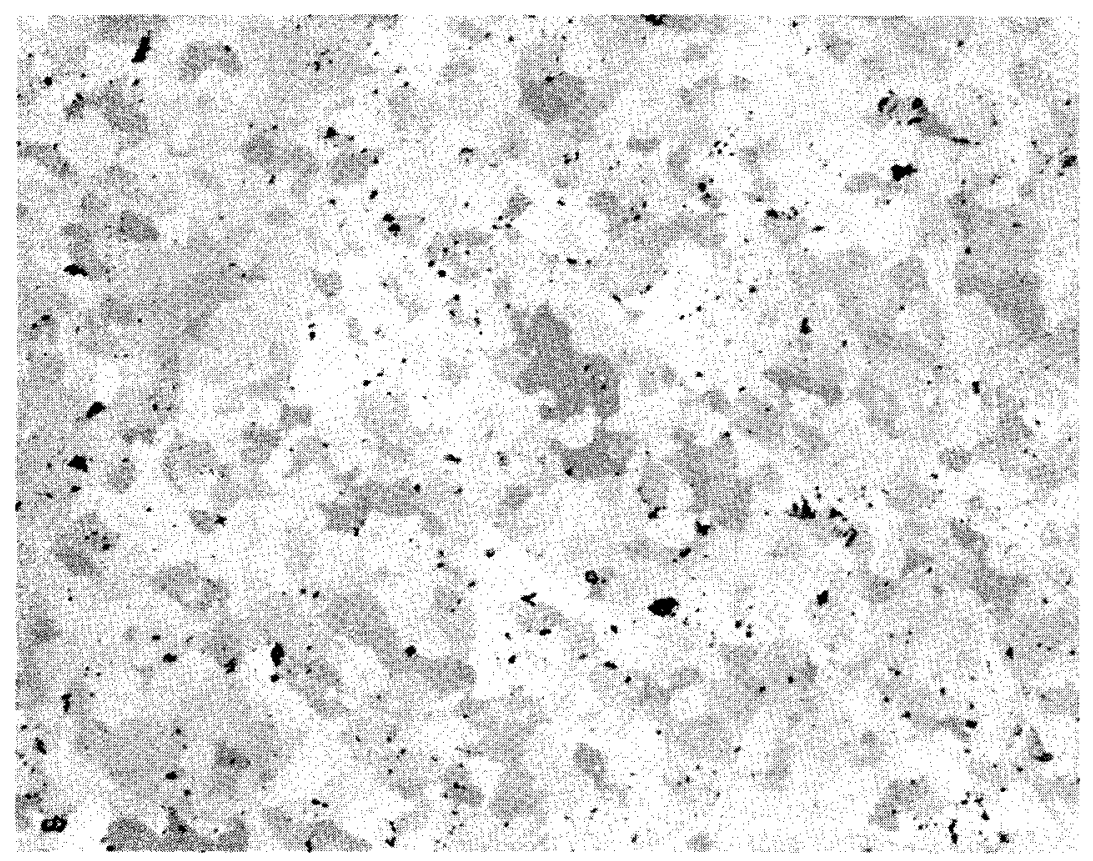

$$
\begin{gathered}
\text { \#1-Limestone - Transverse - } 250 X \\
\text { Negative \#4L1165B }
\end{gathered}
$$




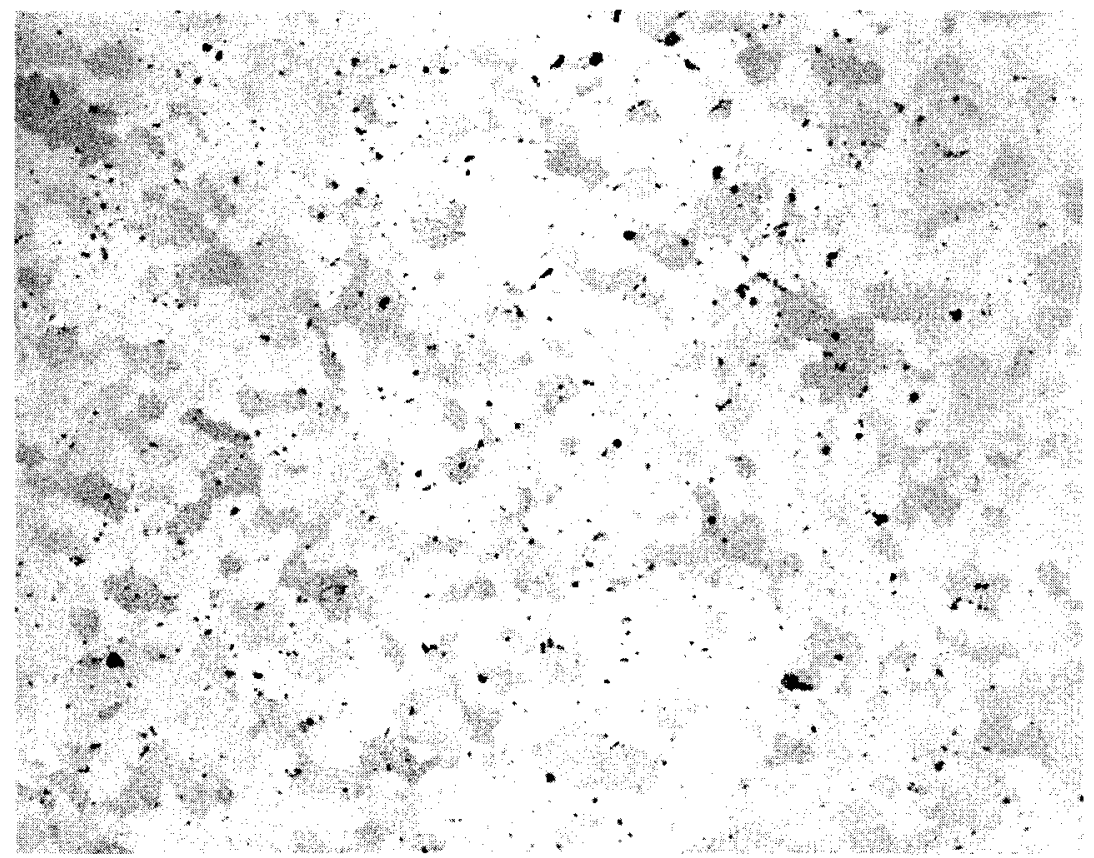

\section{\#1-Limestone - Transverse - 250X \\ Negåtive \#4L1165C}

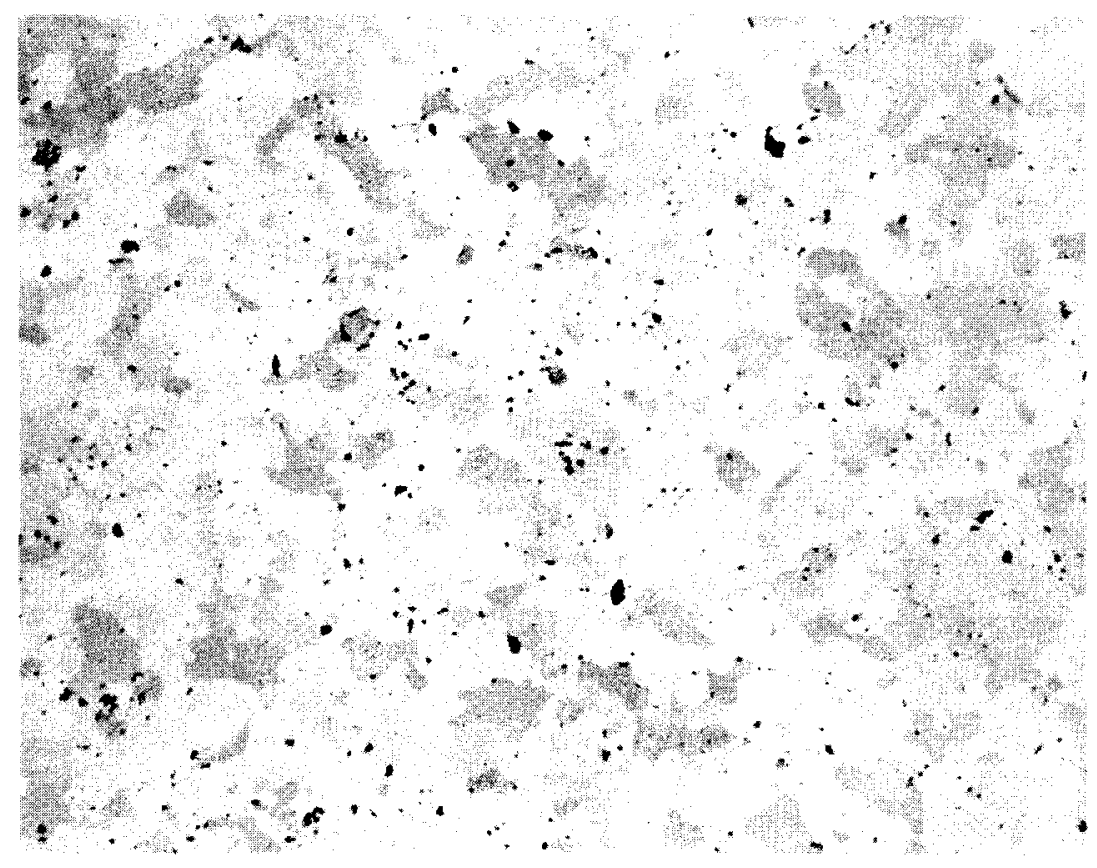

$$
\begin{gathered}
\text { \#1-Limestone - Transverse - } 250 X \\
\text { Negative \#4L1165D }
\end{gathered}
$$




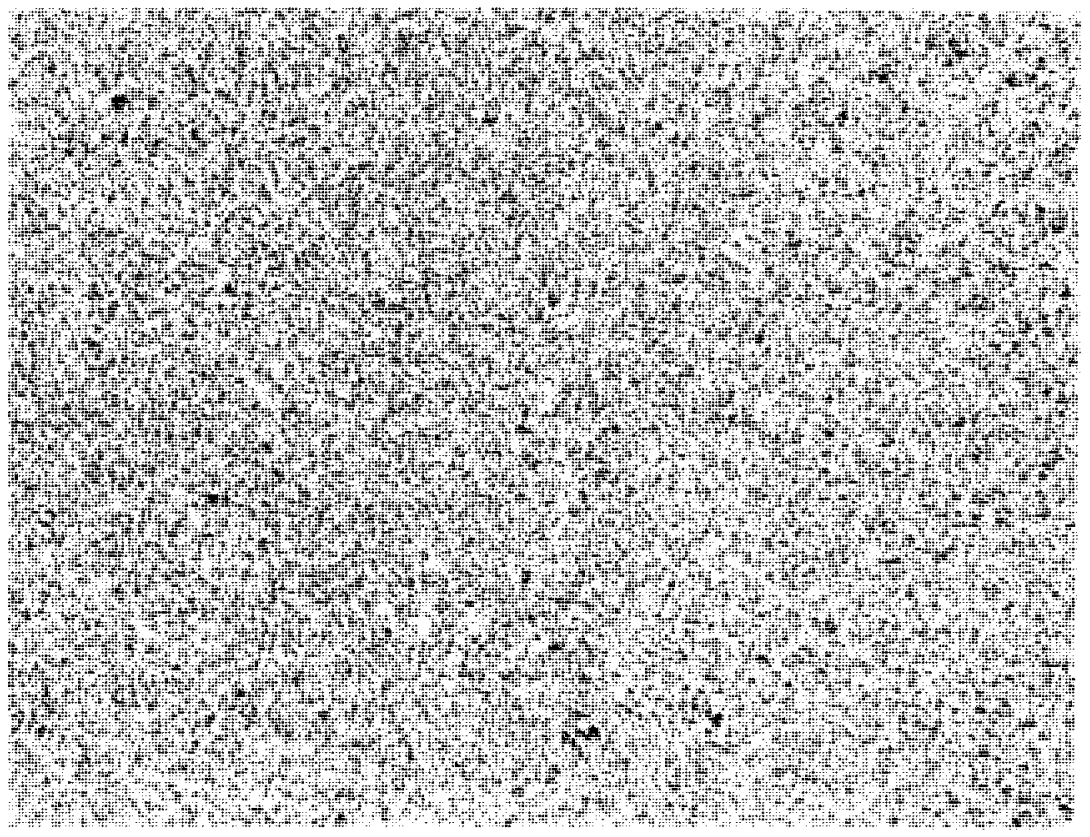

\#2-Sandstone - Longitudinal - 12X
Negative \#4L1166A

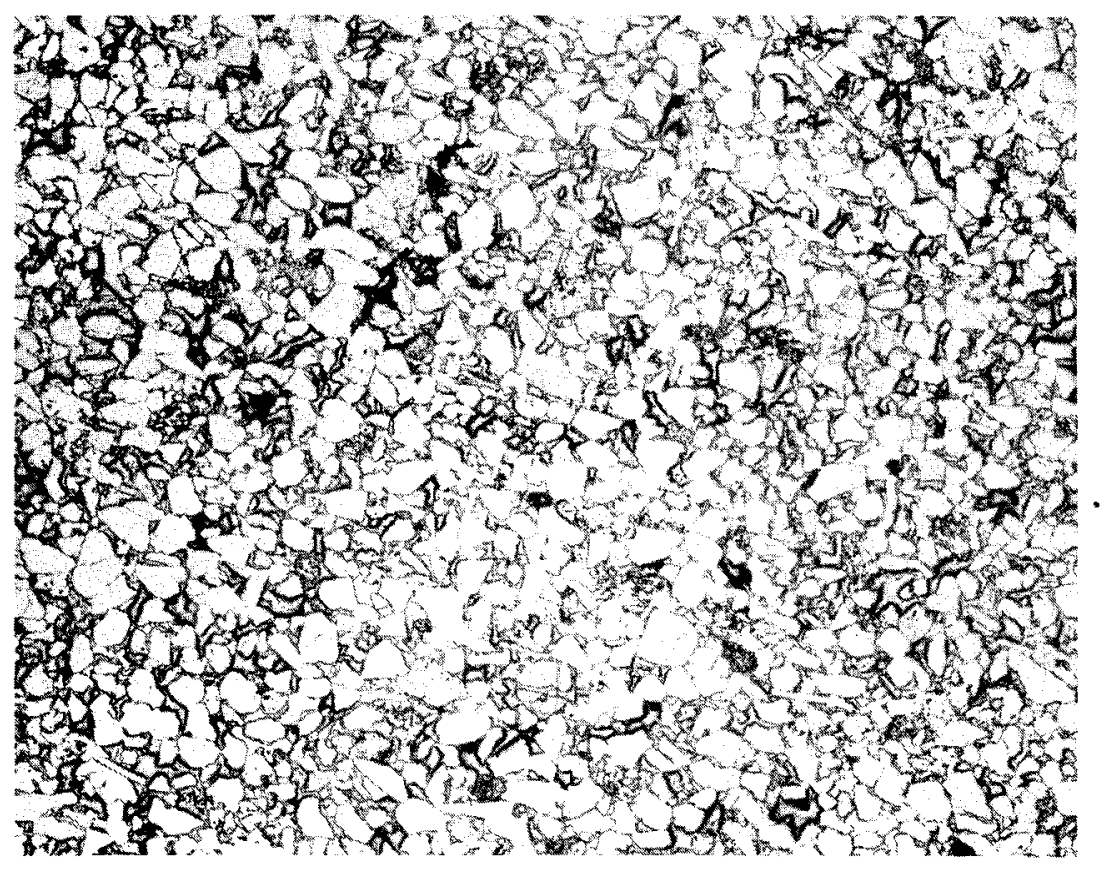

\#2-Sandstone - Longitudinal - 50X
Negative \#4L1166B 

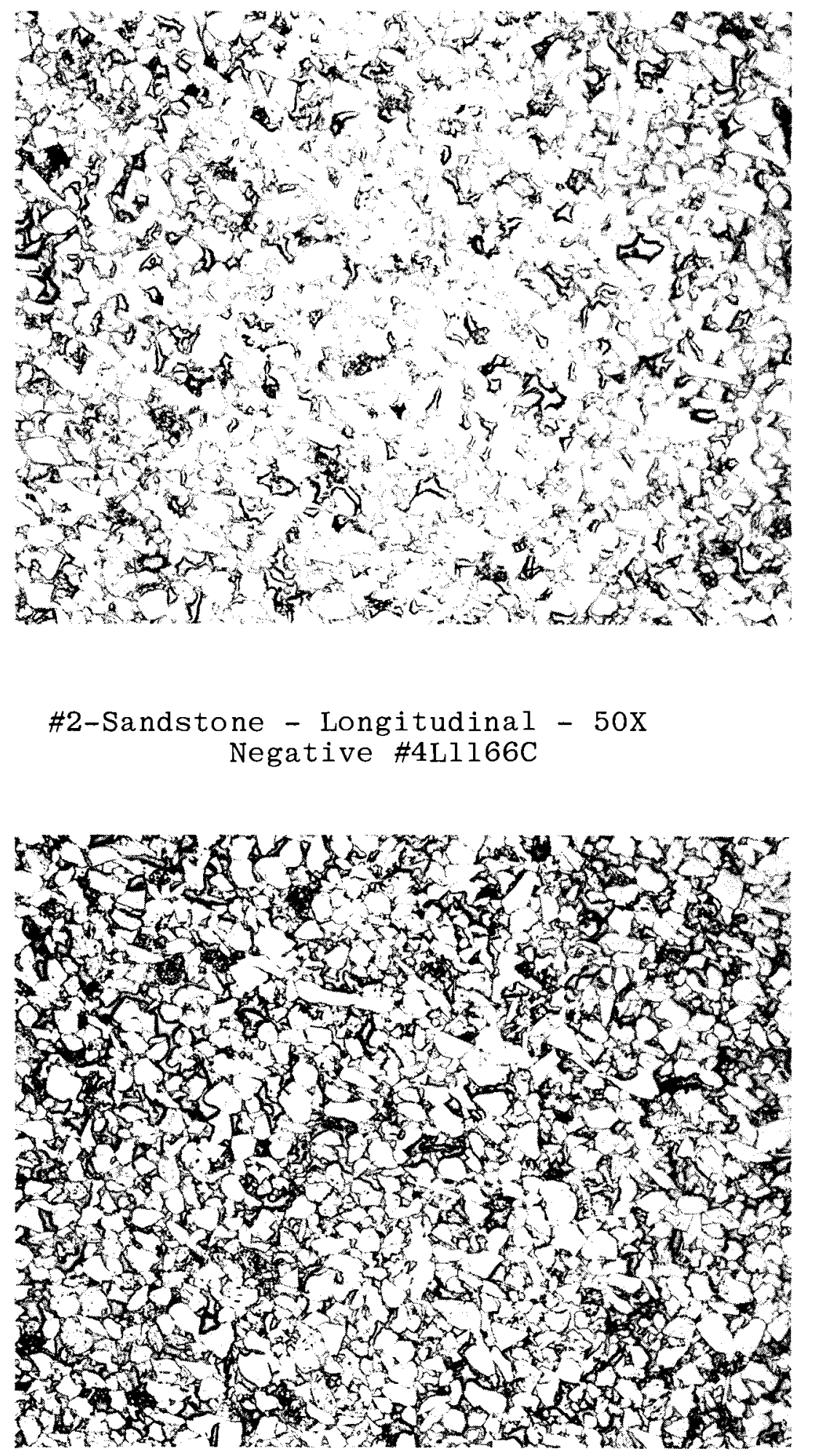

\#2-Sandstone - Longitudinal - 50X
Negative \#4L1166D 

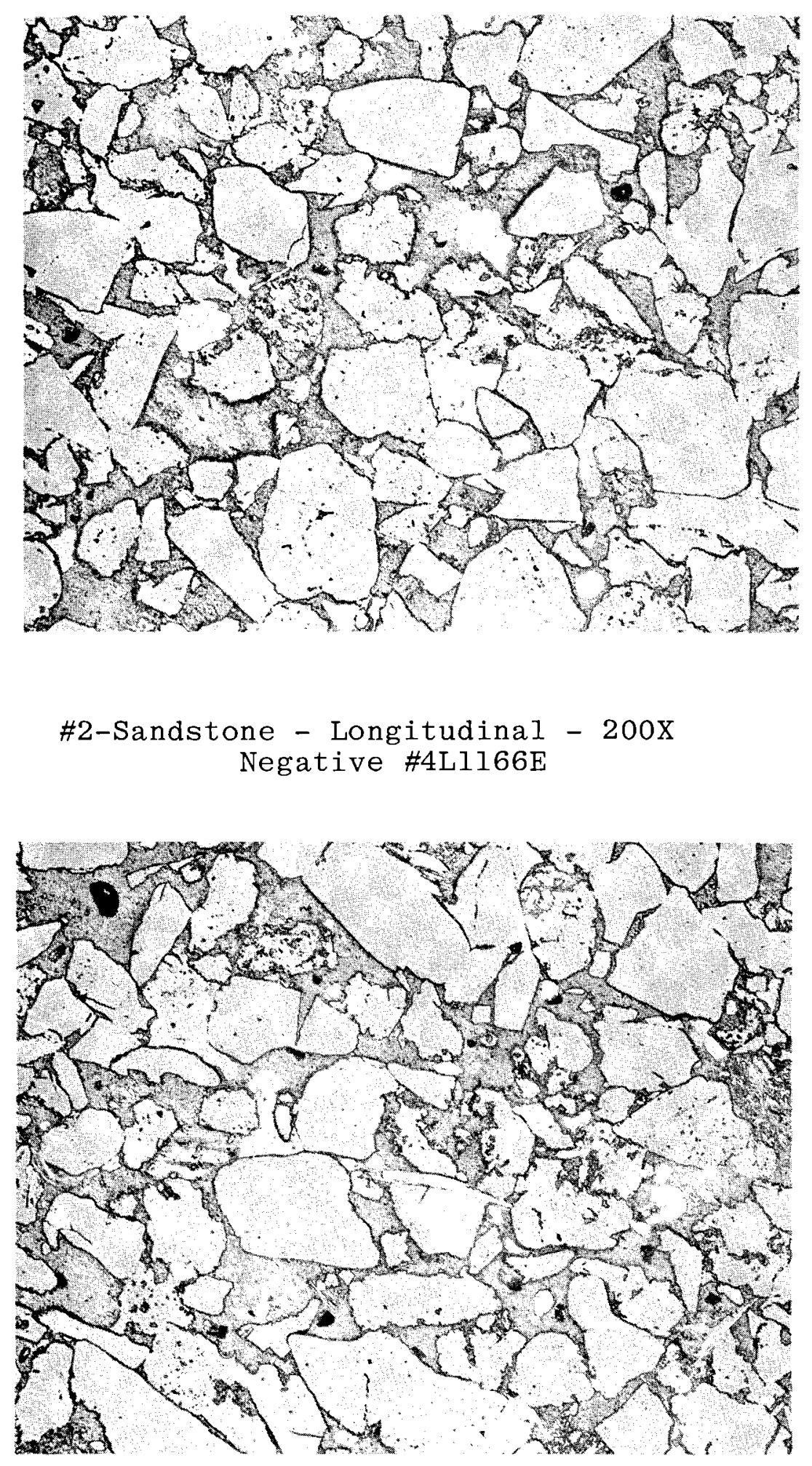

$$
\begin{gathered}
\text { \#2-Sandstone - Longitudinal - 200x } \\
\text { Negative \#4L1166F }
\end{gathered}
$$




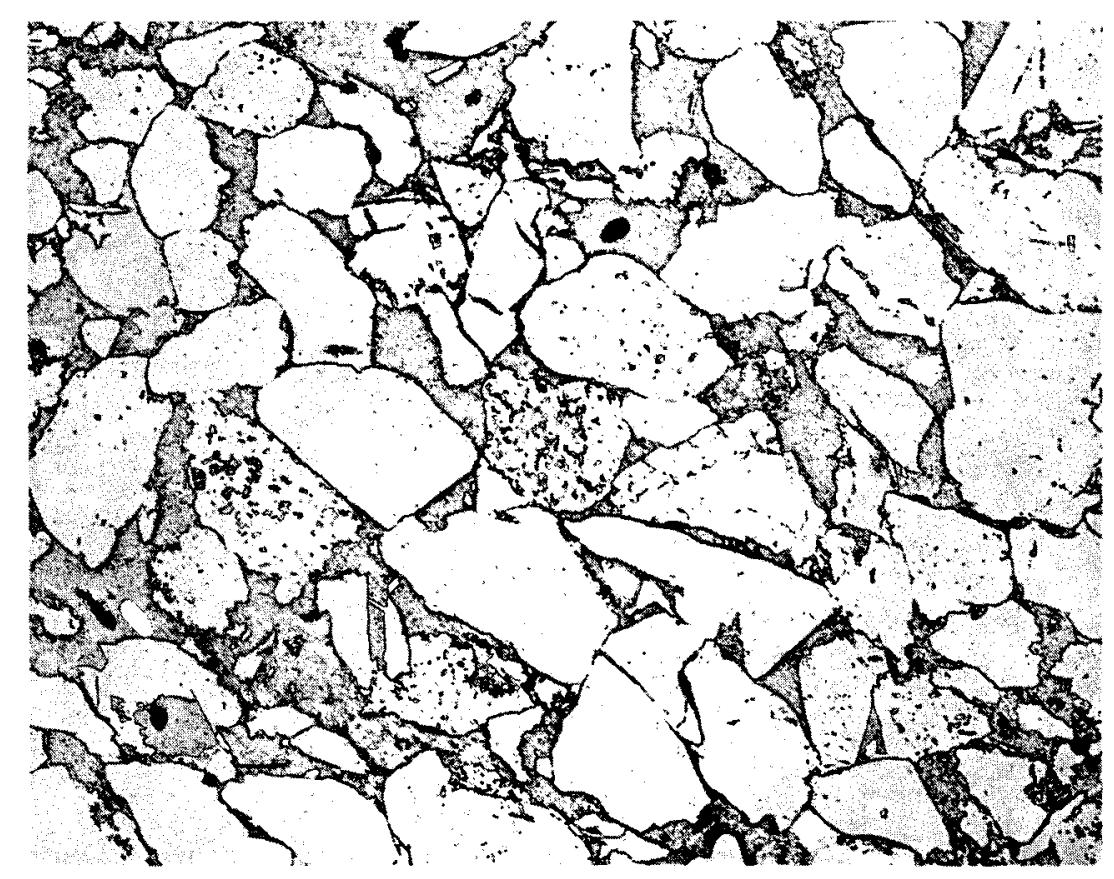

\#2-Sandstone - Longitudinal - 200X

Negative \#4L1166G

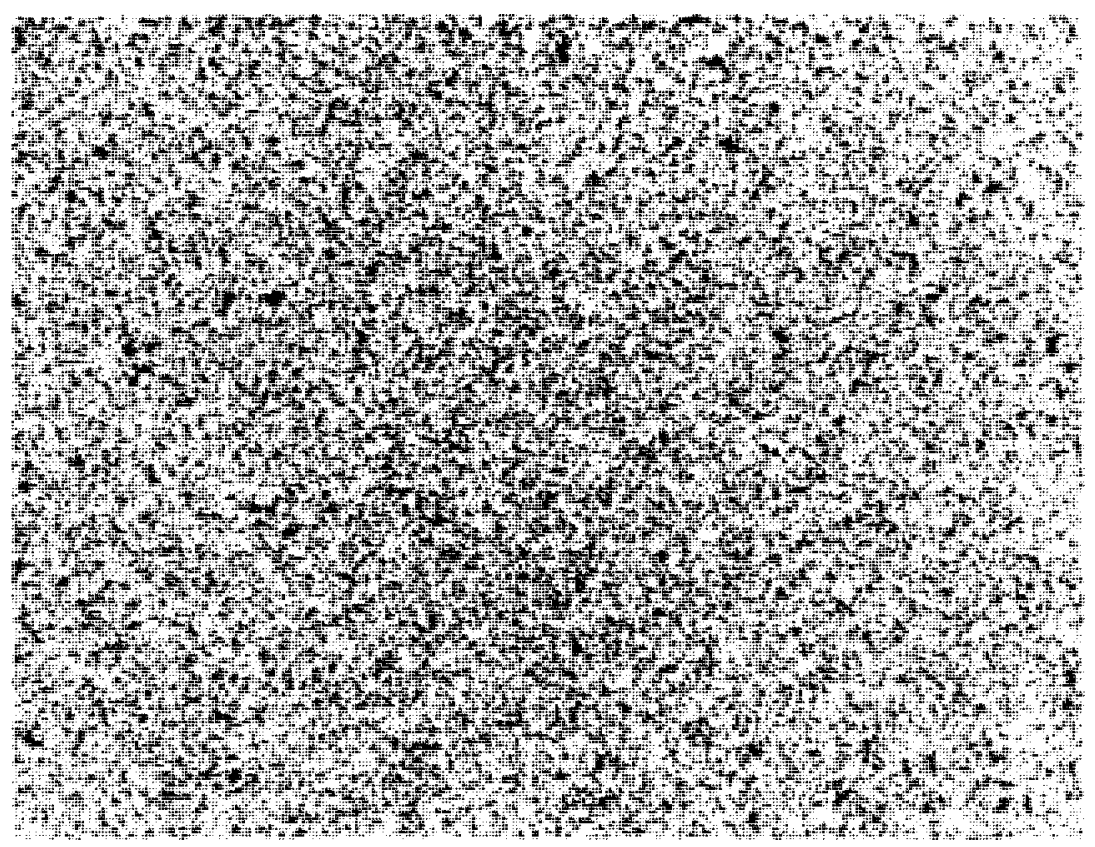

\#2-Sandstone - Transverse - 12X

Negative \#4L1167A 

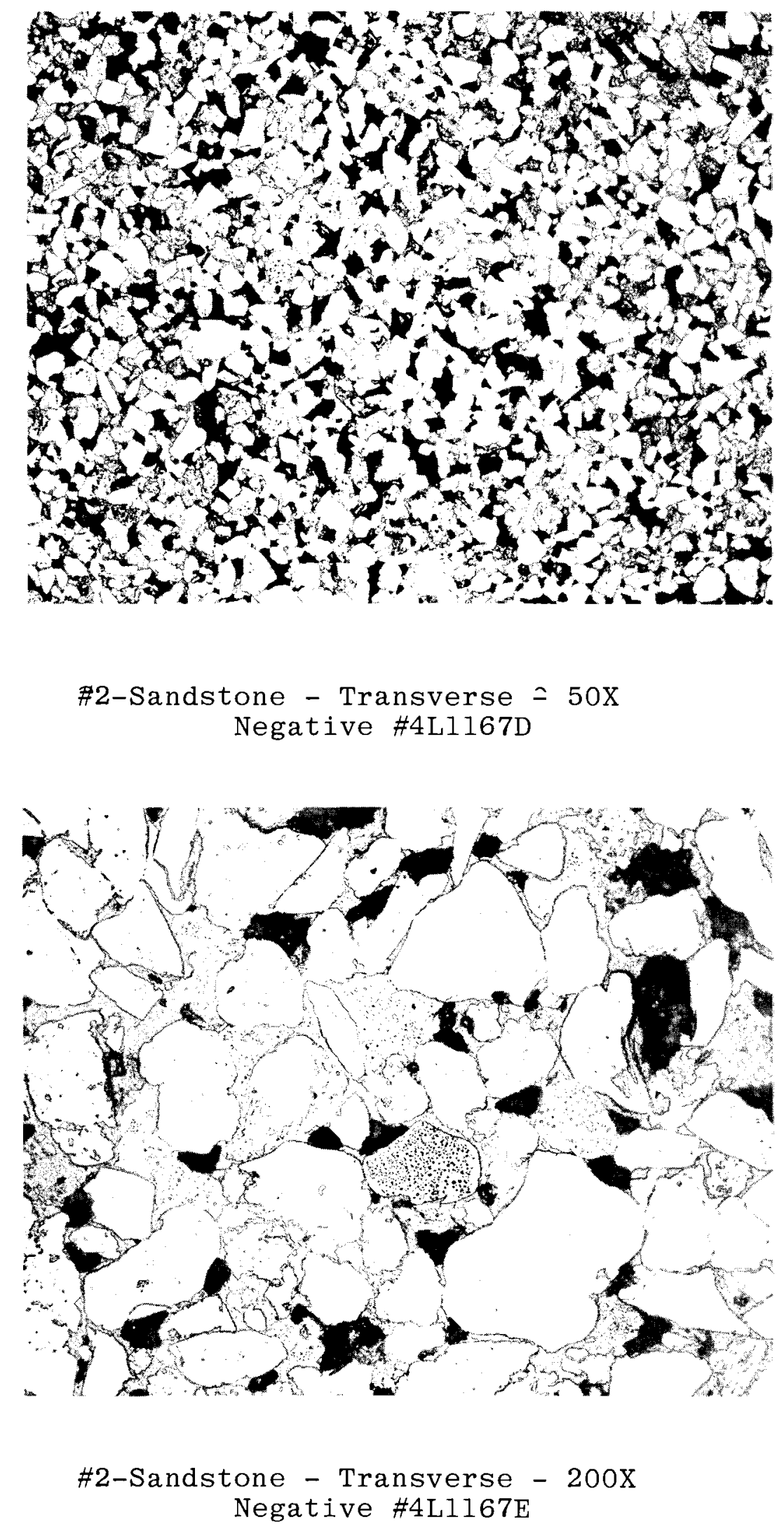


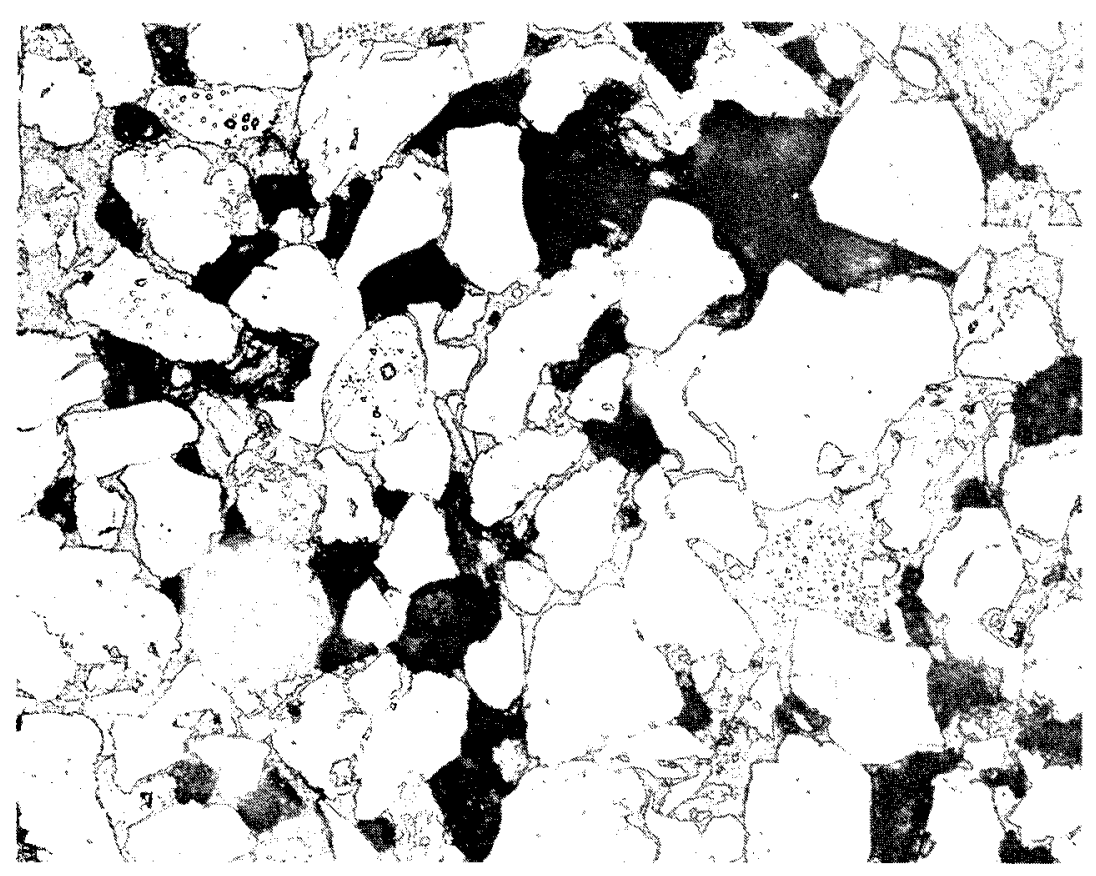

$$
\begin{gathered}
\text { \#2-Sandstone - Transverse - 200X } \\
\text { Negative \#4LIl67F }
\end{gathered}
$$

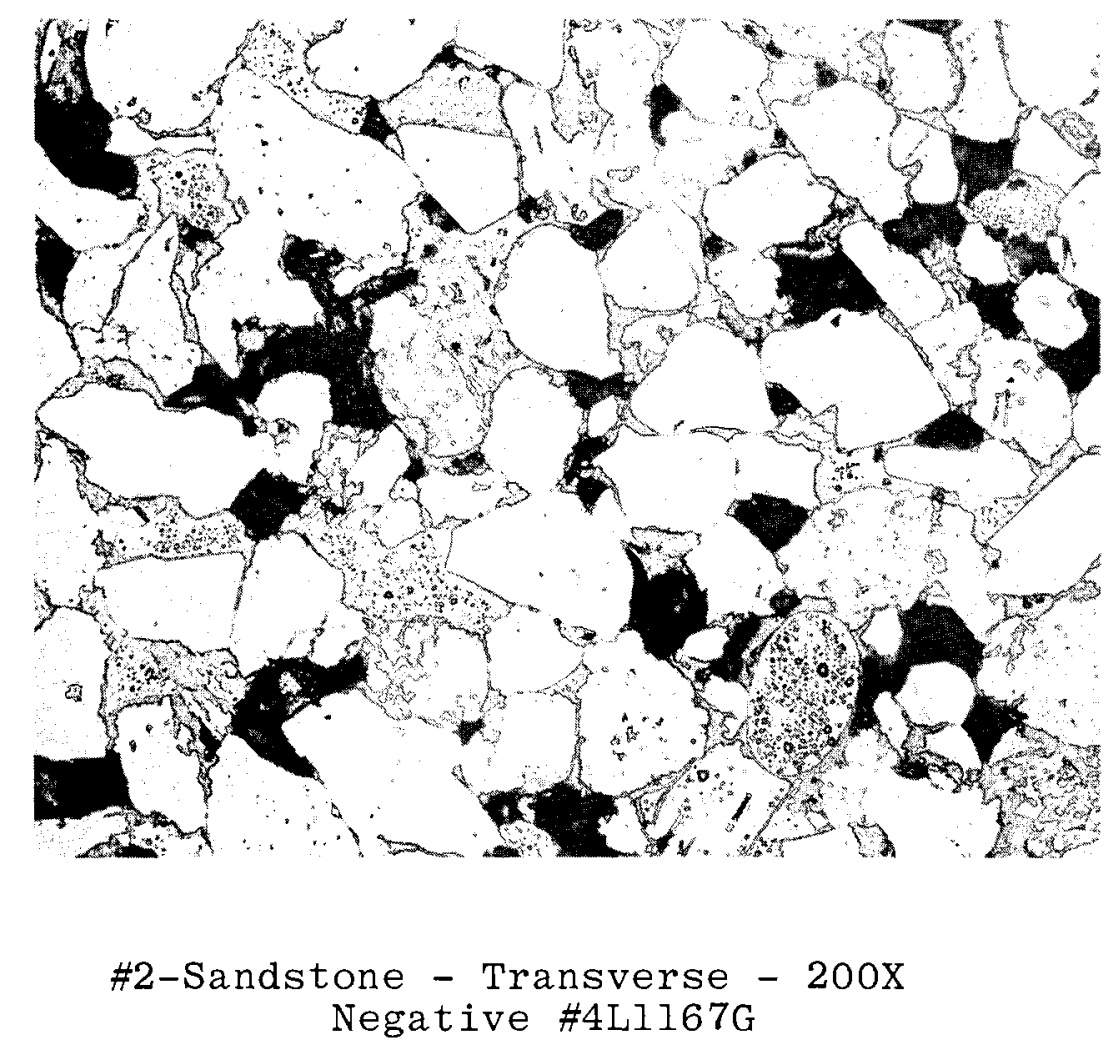




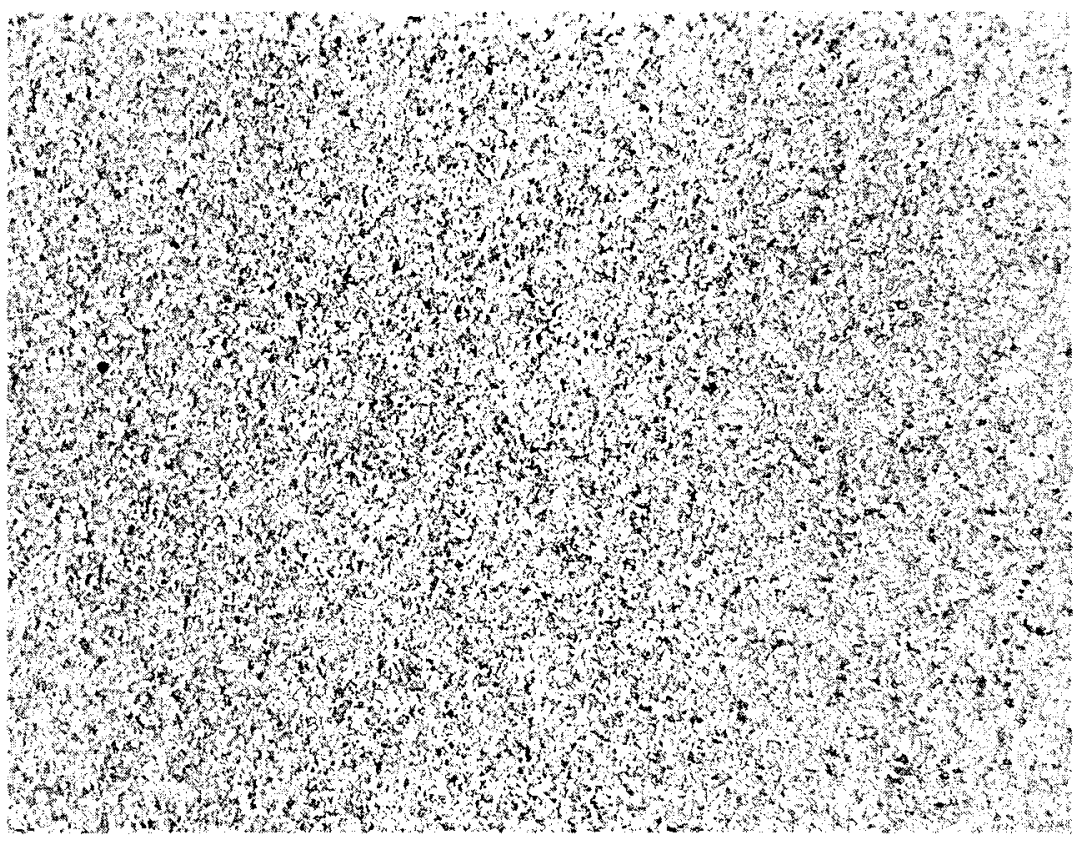

\#3-Sandstone - Longitudinal - 12X
Negative \#4L1168A

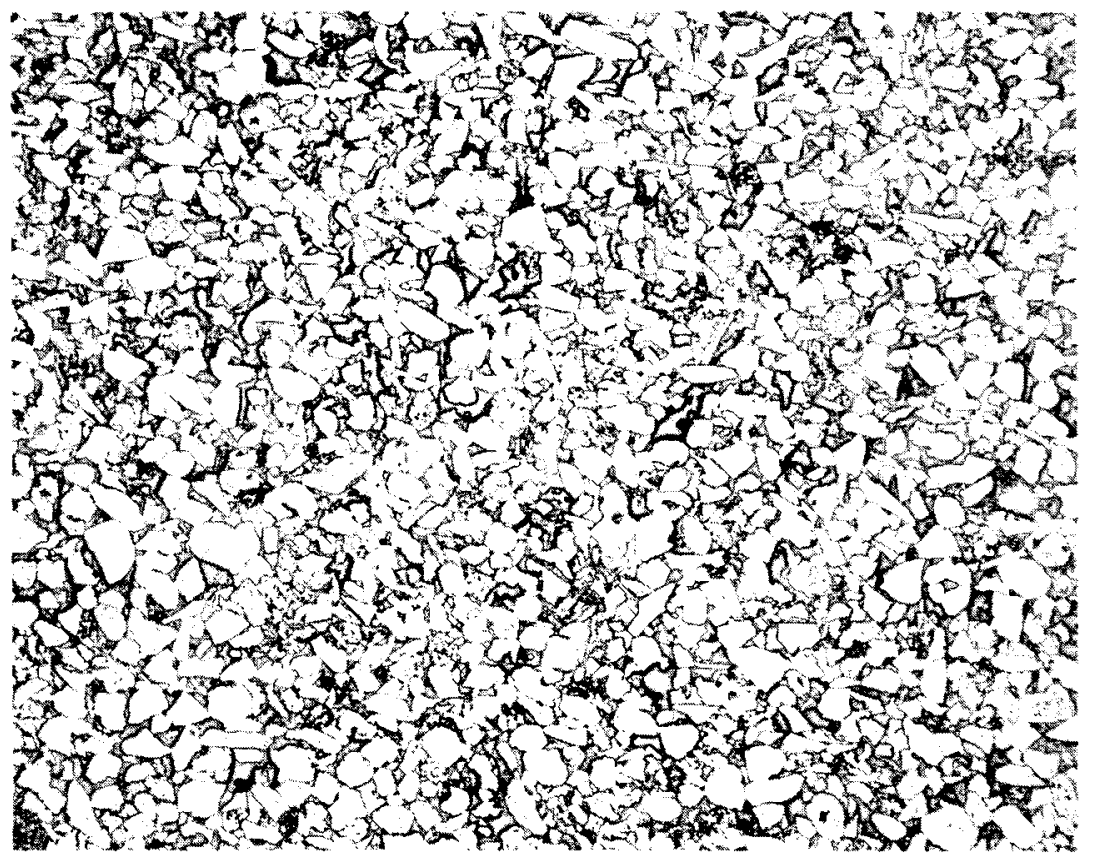

\author{
\#3-Sandstone - Longitudinal - 50X \\ Negative \#4Ll168B
}




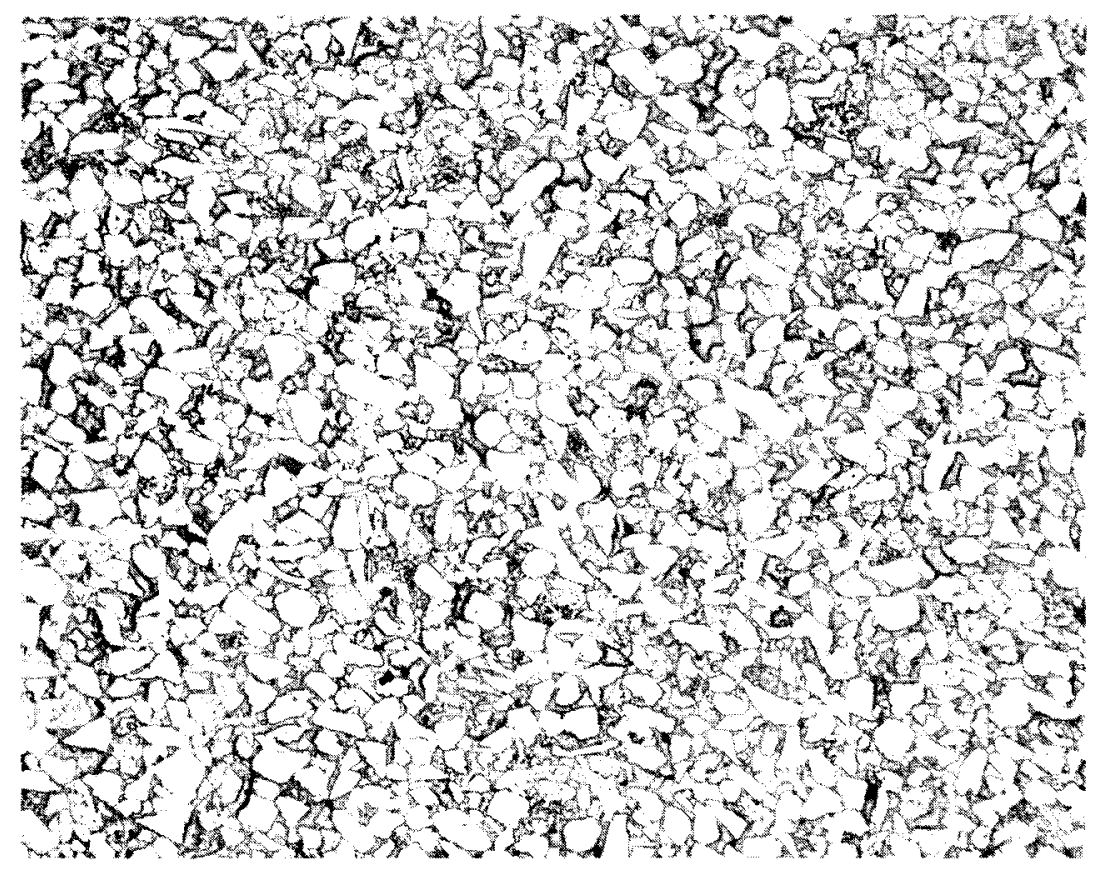

\author{
\#3-Sandstone - Longitudinal - 50X \\ Negative \#4L1168C
}

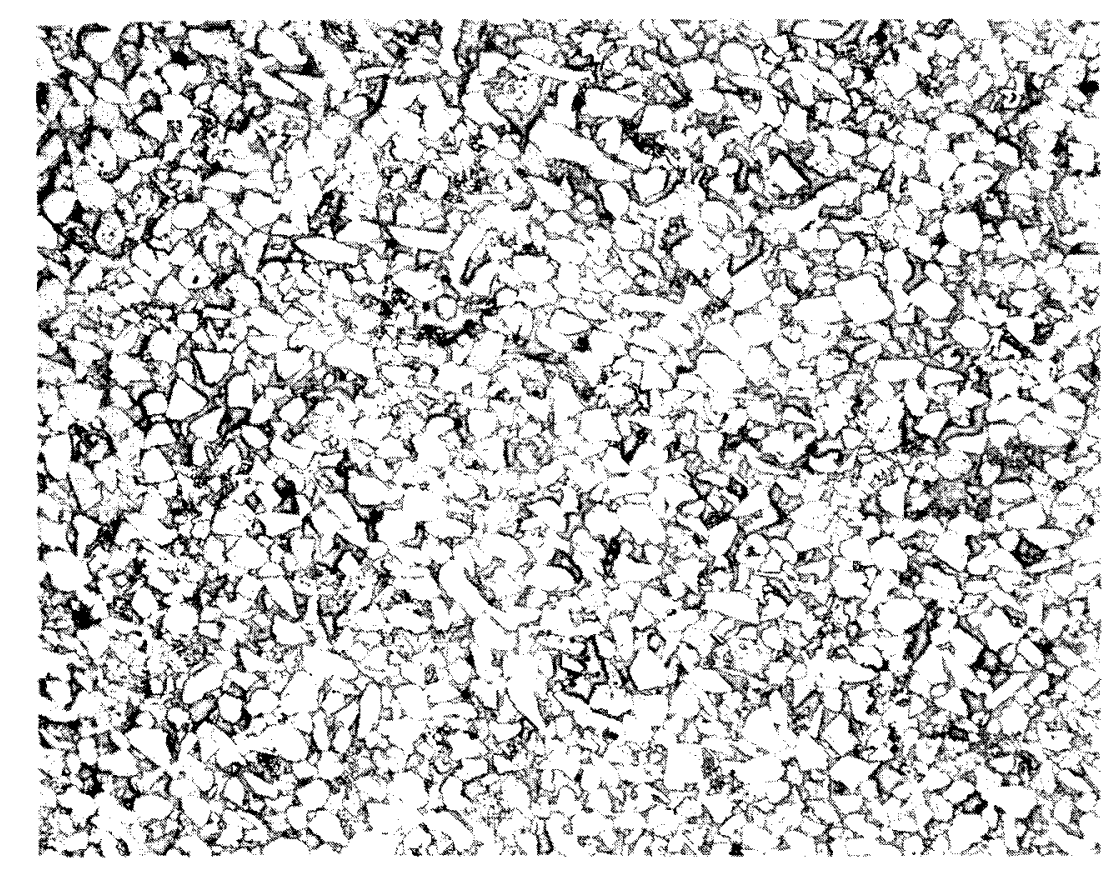

$$
\begin{gathered}
\text { \#3-Sandstone - Longitudinal - 50X } \\
\text { Negative \#4L1168D }
\end{gathered}
$$




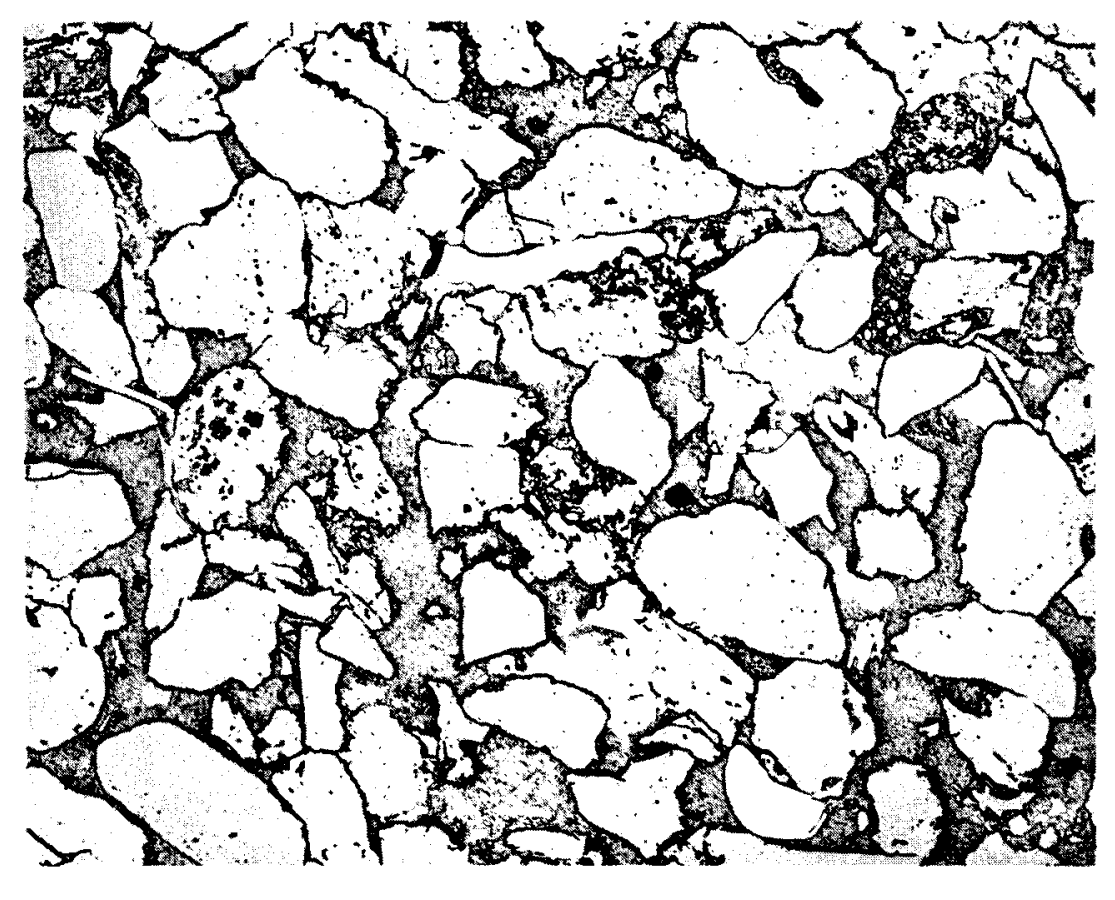

$$
\begin{gathered}
\text { \#3-Sandstone - Longitudinal - 200X } \\
\text { Negative \#4L1168E }
\end{gathered}
$$

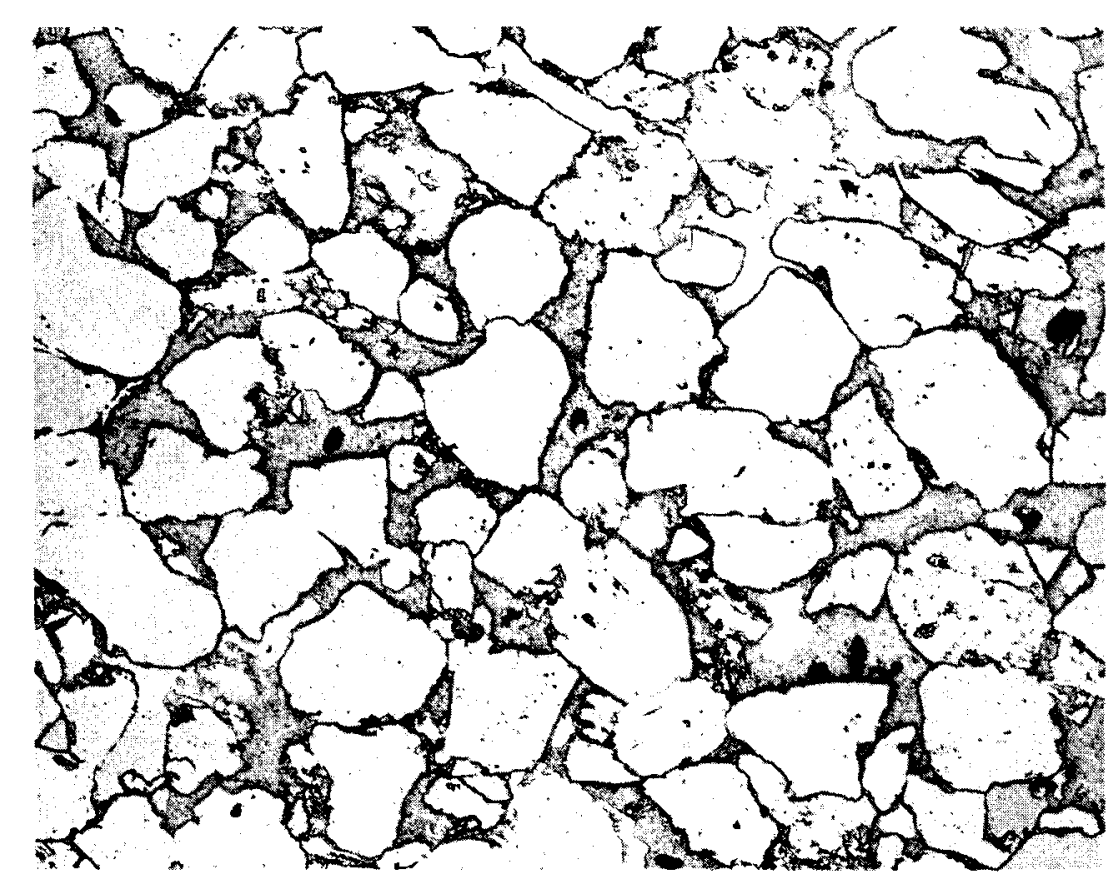

$$
\begin{gathered}
\text { \#3-Sandstone - Longitudinal - 200X } \\
\text { Negative \#4L1168F }
\end{gathered}
$$




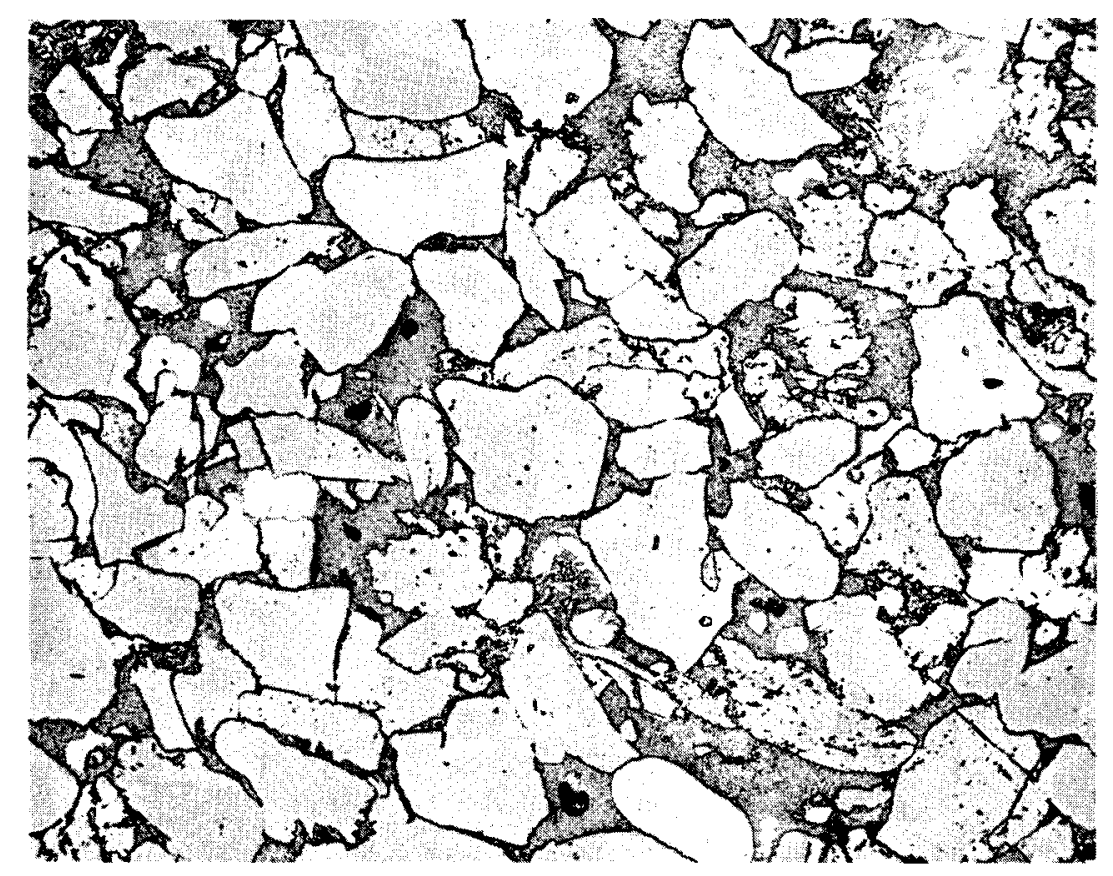

\section{\#3-Sandstone - Longitudinal - 200X Negative \#4L1168G}

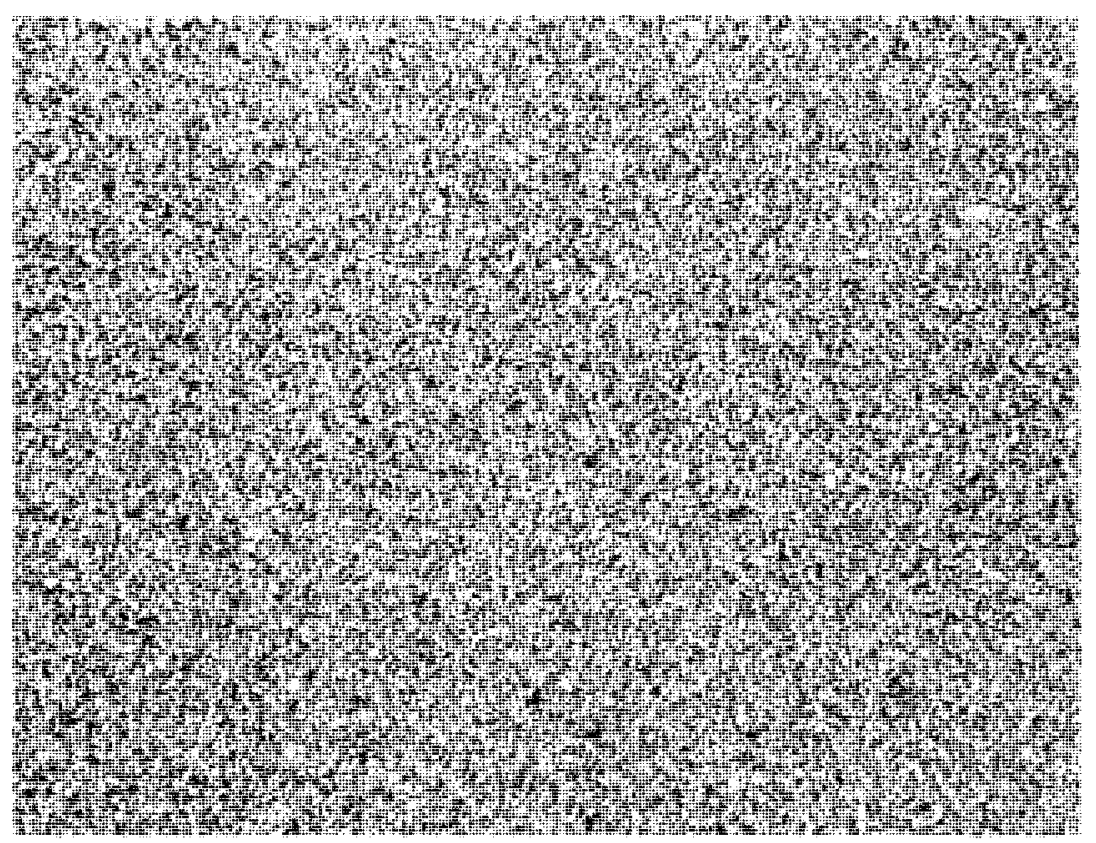

\#3-Sandstone - Transverse - 12X Negative \#4L1169A 


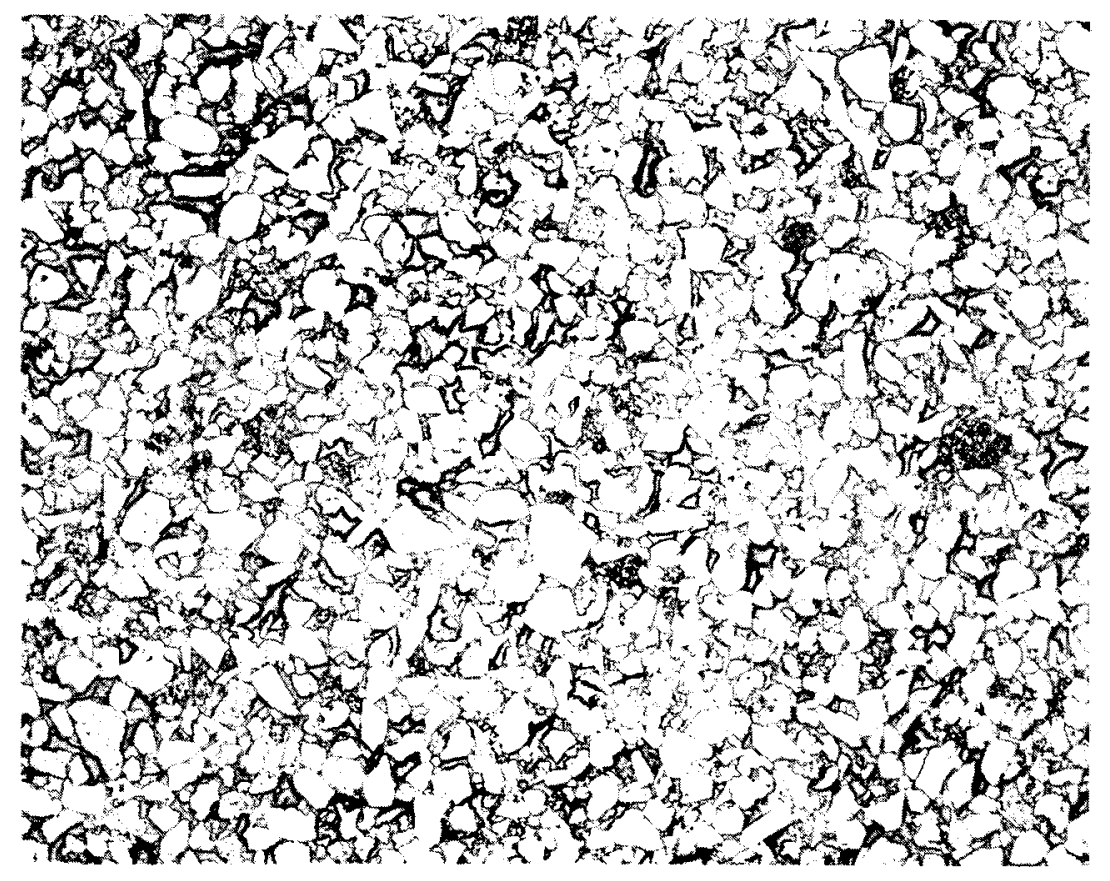

\author{
\#3-Sandstone - Transverse - 50X \\ Negative \#4L1169B
}

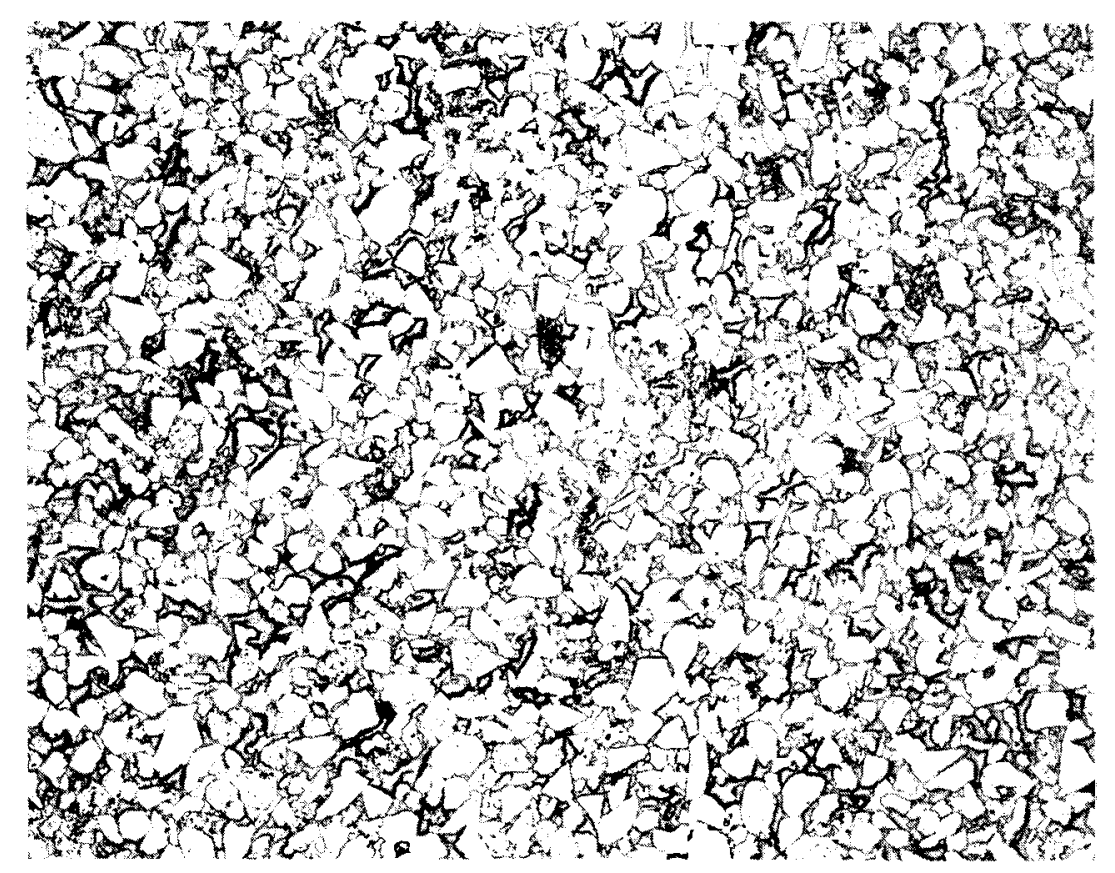

\#3-Sandstone - Transverse - 50X
Negative \#4L1169C 

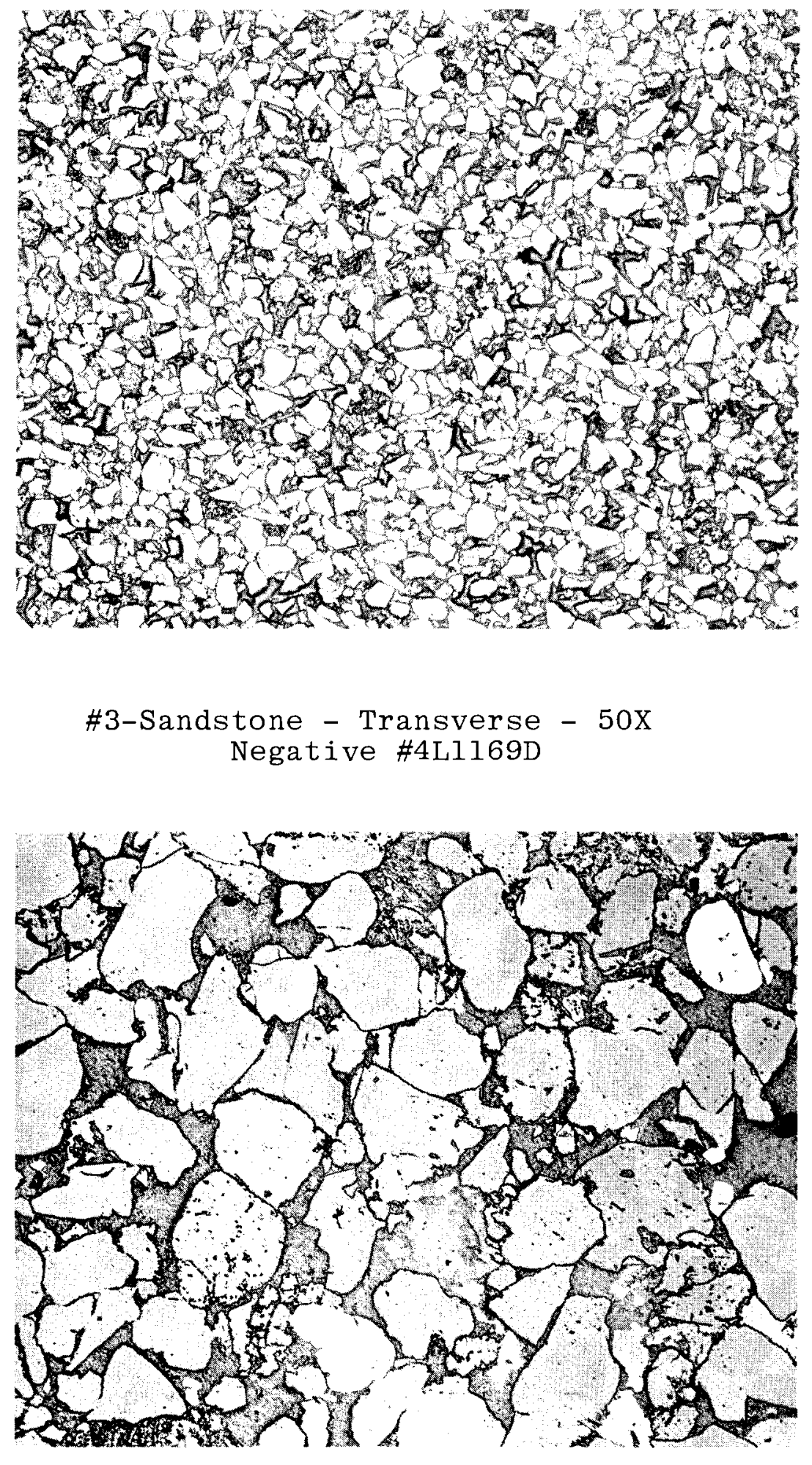

\author{
\#3-Sandstone - Transverse - 200X \\ Negative \#4L1169E
}



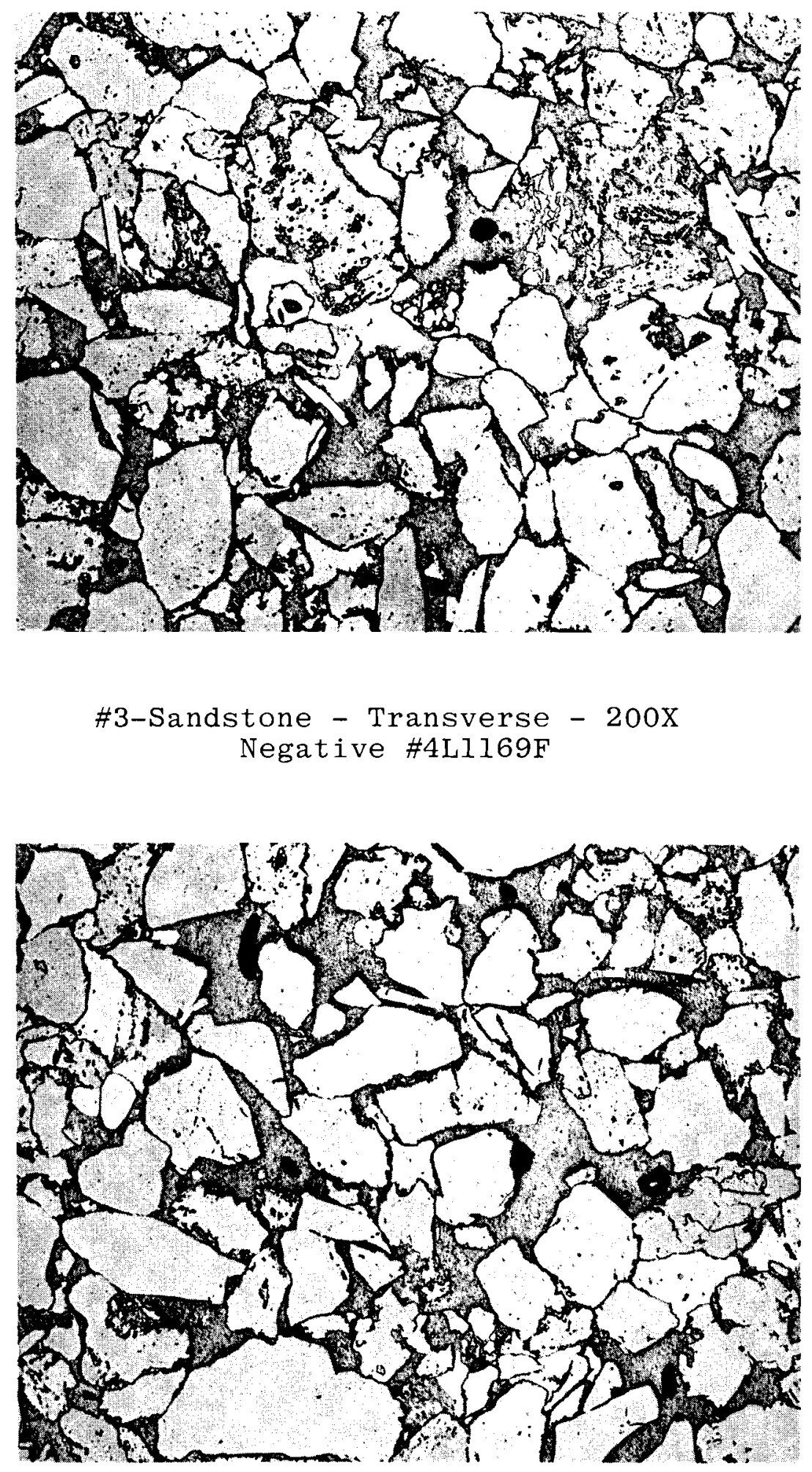

$$
\begin{gathered}
\text { \#3-Sandstone - Transverse - } 200 \mathrm{X} \\
\text { Negative \#4L1169G }
\end{gathered}
$$


APPENDIX B

CARRIER SOLUTION COMPOSITIONS 
date: August 11, 1976

10: Distribution

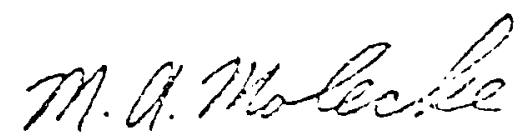

from. M. A. Molecke - 1141
Aluvquerque. New Niexico Livermore. Califurnia

subject: Representative Simulated Brines For WIPP Experimentation

This memo is intended to provide the ionic composition of two representative saturated brines to be utilized by the various laboratory groups supporting the WIPP project. For uniformity and intercomparison purposes, these particular brines, plus distilled water, should be utilized in all distribution coefficient, leaching, corrosion, ion mobility, etc. tests.

The composition of "BrineXA" is based on analyses of concentrated brines from the Salado region. This is a potash bearing region and is consequently quite rich in potassium

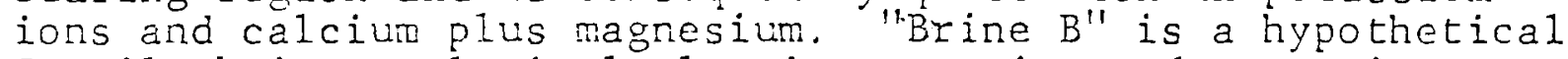
Castile brine, relatively low in potassium and magnesium content. Both brines are essentially saturated with respect to sodium chloride. Brines $X A$ " and " $X B^{\prime \prime}$ represent brines which may theoreticaliy intrude upon the waste repository horizon from both overlaying and underlaying regions, respectively.

The pit of the two brine simulants should be adjusted to about pii $=6.5$, the slight acidity of quite a few "as measured" brine samples. The pH of the prepared brine simulants can be adjusted with small additions of either HCl or Naoti, as necessary.

Future experimental work is being planned to utilize a nonsaturated brine/groundweter and brines of differing pH. This will be the topic of a future meno. 


\section{REPRESENTATIVE SIMULATED BRINES FOR}

\section{WIPP EXPER IMENTATION}

ion

$\mathrm{Na}^{+}$

$\mathrm{K}^{+}$

$\mathrm{Mg}^{++}$

$\mathrm{Ca}^{++}$

$\mathrm{Fe}^{+++}$

$\mathrm{Sr}^{++}$

$\mathrm{Li}^{+}$

$\mathrm{Rb}^{+}$

$\mathrm{Cs}^{+}$.

$\mathrm{Cl}^{-}$

$\mathrm{SO}_{4}^{--}$

B (as $\mathrm{BO}_{3}^{-\cdots}$ )

$\mathrm{HCO}_{3}{ }^{-}$

$\mathrm{Br}^{-}$

$I^{-}$

specific gravity

$\mathrm{pH}$ $\frac{\text { "Brine } X_{A} "}{\text { (mg/liter) }}$

57,000

52,000

38,000

1,300

50

20

20

20

10

240,000

7,000

1,200

700

400

10

$\sim 1.2 \mathrm{~g} / \mathrm{cc}$

6.5 $\frac{\text { "BrineX }}{\text { (mg/Iiter) }}$

115,000

5,000

1,000

800

50

20

20

20

10

200,000

10,000

1,200

700

400

10

$\sim 1.2 \mathrm{~g} / \mathrm{cc}$

6.5

Note: Distilled water should be utilized for WIPP experimentation in addition to brines "XA" and $X_{B}$." 
(dato: October 3,1976

10. Distribution

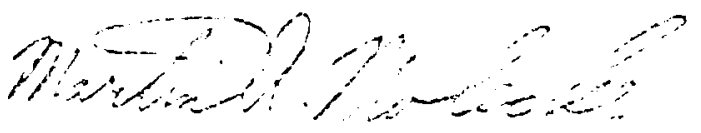

from: M. A. Molecke - 1141

Sublect Revised Fepresentative Brines/SoIutions for WIPP Experimentetion

This memo is intended to provide specifications for the ionic content and chenical formultions for three sollitions/brines for experimentai purposes. These solutions are representative of waters wich can potentially intrude into the Waste Isolation Pilot Plant. Brine transport of radionuclides from the radioactive raste stored in a salt mine into the seosphere and bicsphere are of major concern. Experiments in progress or planned (at Sandia pius other laboratories) to quantify and eraluate such transport plus related aspects of brine intrusion include: radionuclide distribution coefficiert measurements, waste matrix leaching, radionliclide mobility and interactions, and corrosion aspects. The various laboratory grouss supporting tie WIPP project should utilize the specified brines/solutions for both uriformity and intercomparison purposes.

The ionic compositions of the representative brines/solutions "A", "B", and "C" are given in Table I, attached, in units oi mg/liter of solution. To facilitate preparation of these solutions, the required chemical compounds, also in units of mg added per liter of solution, are presented in Table II. AlI ions adied have been balancor in terms of milliequivalents/2iter for both cations and anions. If substitutions are made for various compouris in preparation, rebalancing calculations will. be necessary. Following preparation, the pH of the solutions should be adjusted, as specified, with smail additions of either dilute $\mathrm{HCl}$ or $\mathrm{NaOH}$, as required. The specified pH vallies or solutions "A", "B", and "Cl" are representative of the "as measurej" DI's of the naturaliy occurring solutions on which they are oased.

Solutions "A" and "B" are near-saturated brines. Solution "A" is based on the anajyses of several brines from the Salado region overlying the piarned WIFE facility/horizon. This is a potash bearing region end conseguently is enriahed in both notassium and magnesium ions, relative to sodium chloride. Solution "A" is intenced to be representative of brine which could intrude into the waste horizon via ilcw or percolation from above. 
Distribution $\quad-2-\quad$ October 8, 1976

Solution " $B$ " is based on the analysis of the brine obtained by dissolving a portion of rock salt core in de-ionized water. The salt core was Irom AEC $\# B$ at approximately the same horizon (2725 ft.) as the intermediate-level waste and high-level waste experiment horizon of the WIPP facility. Since the AEC \#8 hole is less than four miles from the center of the WIPP facility, no significant differences in the salt content are expected. This analyzed brine has an approximately $98 \% \mathrm{NaCl}$ content and a total undissolved content (not included in analysis) of less than 1\%. Solution "B" is representative of the brine resulting from a conceivable catastrophic scenario at the WIPP mine (flood.ing, service water line rupture, etc.) whereby water pours in, dissolves the salt, becomes saturated, then begins to attack the waste.

Solution "C" is representative of groundwater pumped from one of the aquifers in the Rustler formation. This potable water was sampled near the WIPP location. The solution "C" composition is based on two separate analyses; it consists primarily of a dilute solution of calcium and magnesium sulfates. Being representative of the WIPP hydrological and geographical locale, solution "C" was deemed more suitable for experimental tests and intercomparisons than was de-ionized vater. Once tracers and geological specimens are added to de-ionized water, it no longer simulates de-ionized water. The higher ionic strength of solution "C" solves this problem.

This memo supercedes my memo entitled "Representative Simulated Brines for WIPP Experimentation," dated August 11, 1976. The brines specified there were based on commercial brine analyses which were erroneously high for several ions. This resulted in greater than saturated solutions. Brines/solutions "A", "B", and "C" have been tested in-house for solubility.

MAM: II4I:' IIk 


\section{TABLE I}

REVISED REPRESENTATIVE BRINES/SOLUTIONS

FOR

WIPP EXPERIMENTATION

Ion
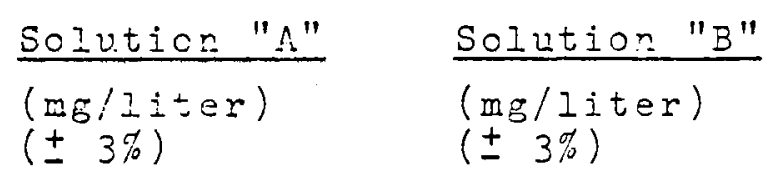

Solution "C"

(mg/liter)

$( \pm 3 \%)$

$( \pm 3 \%)$

$( \pm 3 \%)$

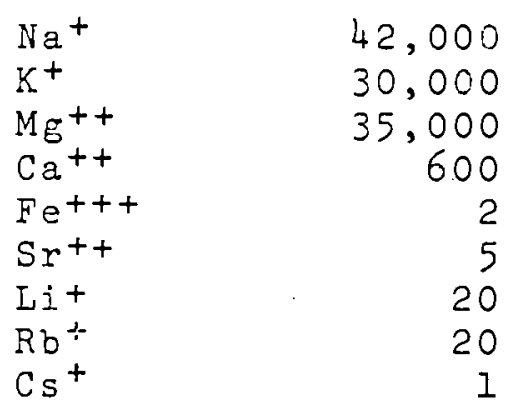

115,000

100

15

10

900

5

200

600

2

20

20

1

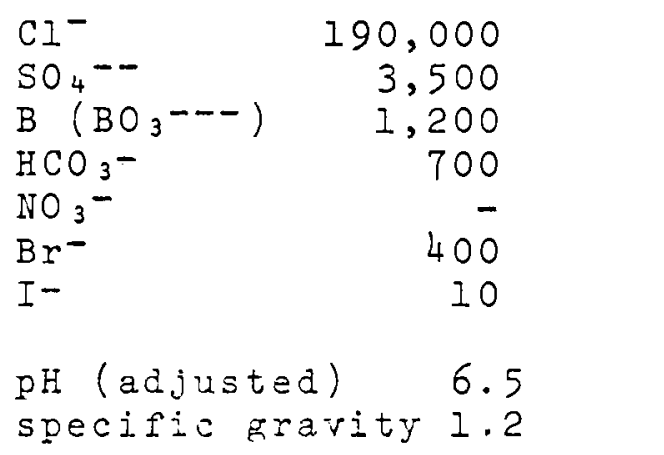

190,000

2

1

15

15

$\begin{array}{ll}- & - \\ 1 & 1\end{array}$

$\begin{array}{lr}\mathrm{CI}^{-} & 190,000 \\ \mathrm{SO}_{4}^{--} & 3,500 \\ \mathrm{~B}\left(\mathrm{BO}_{3}--\right) & 1,200 \\ \mathrm{HCO}_{3}^{-} & 700 \\ \mathrm{NO}_{3}^{-} & - \\ \mathrm{Br}^{-} & 400 \\ \mathrm{I}^{-} & 10 \\ & \\ \mathrm{pH} \mathrm{(adjusted)} & 6.5 \\ \text { specific gravity } & 1.2\end{array}$

175,000

3,500

10

10

400

10

200
1,750
100
20
-
-

6.5

1.2

$7 \cdot 5$

1.0 
TADIE II

RECOMMENDED CHEMICAL COMPOUNDS FOR

PREPARING REPRESEITATIVE BRINES/SOIUTIONS

FOR

WIPP EXPERIMENTATION

$$
2100^{\prime}
$$

$=90^{\prime}$

Compound

$\frac{\text { Solution "A" }}{\text { (mg/liter) }} \quad \frac{\text { Solution "B" }}{\text { (mglliter) }} \quad \frac{\text { Solution "C" }}{\text { (mg/liter) }}$

$\mathrm{NaCl}$

$\mathrm{Na}_{2} \mathrm{SO}_{4}$

$\mathrm{Na}_{2} \mathrm{~B}_{4} \mathrm{O}_{7} \cdot \mathrm{IOH}_{2} \mathrm{O}$

$100.10 \%$

$6.20 \overrightarrow{5}$

$1.95 \mathrm{~g}$

960

$\mathrm{NaH} C \mathrm{O}_{3}$

$\mathrm{NaBr}$

520

$\mathrm{NaNO}_{3}$

$\mathrm{KCl}$

$\mathrm{KI}$

$\mathrm{MgCl}_{2}$

$\mathrm{MgSO}_{4}$

$\mathrm{CaCl}_{2} \cdot 2 \mathrm{H}_{2} \mathrm{O}$

$\mathrm{CaSO}_{4} \cdot 2 \mathrm{H}_{2} \mathrm{O}$

FeCl 3

$\mathrm{SrCl}_{2} \cdot 2 \mathrm{H}_{2} \mathrm{O}$

$\mathrm{LiCl}$

$\mathrm{Rb}_{2} \mathrm{SO}_{4}$

$\mathrm{CsCl}$

$57.2 \overline{0} 8$

137.008

$2.20 \mathrm{~g}$

$\overline{6}$

11

125

30

I. 3

287.008

$6.20 \mathrm{~g}$

15

14

520

-

29

13

40

$-$

$3.30 \mathrm{~g}$

$\overline{6}$

33

1.6

$1 \cdot 3$

170
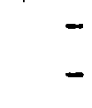

27

9.5

$\mathrm{pH}$ (adjusted)

Total Dissolved

6.5

6.5

$7 \cdot 5$

Solids

$306.3 \mathrm{~g} / 1$ iter

$297.2 g /$ I t

3.72g/1iter 


\section{DISTRIBUTION}

No. of

Copies

\section{OFFSITE}

A. A. Churm

ERDA Chicago Patent Group

9800 South Cass Avenue

Argonne, IL 60439

27 Technical Information Center

W. C. Luth

Division of Physical Research

U.S.E.R.D.A.

Washington, DC 20545

R. L. Watters

Division of Biomedica 1 and

Environmental Research

ERDA

Washington, DC 20545

H. C. Claiborne

Office of Waste Isolation

P.0. Box $Y$

Building 9106

Oak Ridge, TN 37830

5 L. R. Dole

Office of Waste Isolation

P.0. Box $Y$

Building 9106

Oak Ridge, TN 37830

R. B. Laughon

Office of Waste Isolation

P.0. Box $Y$

Building 9106

Cak Ridge, TN 37830

W. C. McClain

Office of Waste Isolation

P.0. Box $Y$

Building 9106

Oak Ridge, TN 37830
No. of

Copies

C. D. Zerby

Office of Waste Isolation

P.0. Box $Y$

Building 9106

Oak Ridge, TN 37830

G. H. Jenks

Office of Waste Isolation

P.0. Box $Y$

Building 9106

Oak Ridge, TN 37830

C. W. Francis

Oak Ridge National Laboratory

P.0. Box $X$

Building 2001

Oak Ridge, TN 37830

2 J. A. Apps

Lawrence Berkeley Laboratory

University of California

Building 90, Room 2130

Berkeley, CA 94720

L. D. Ramspott

Lawrence Livermore Laboratory

University of California

P.0. Box 808

Livermore, CA 94550

D. G. Coles

Lawrence Livermore Laboratory

University of California

P.0. Box 308, Mail Code L-233

Livermore, CA 94550

K. E. Apt

Los Alamos Scientific Laboratory

P.0. Box 1663

Los Alamos, NM 87545 
No. of

Copies

D. Hoffman

Group CNC-11

Los Alamos Scientific Laboratory

Mail Stop 514

Los Alamos, NM 87545

M. Wheeler

Los Alamos Scientific Laboratory

P.0. Box 1663

Los Alamos, NM 87545

10 M. Molecke

Sandia Laboratories

P.0. Box 5800

Albuquerque, NM 87115

W. D. Weert

Sandia Laboratories

P.0. Box 5800

Albuquerque, NM 87115

R. B. Dosch

Sandia Laboratories

P.0. Box 5800

Albuquerque, NM 87115

I. W. Marine

E. I. du Pont de Nemours Company

Savannah River Laboratory

Aiken, SC 29801

J. Cleveland

U.S. Geological Survey

Denver Federal Center

Mai1 Stop 412

P.0. Box 25046

Lakewood, CO 80225

G. D. DeBuchananne

U.S. Geological Survey

Reston, VA 22092

D. B. Stewart

U.S. Geological Survey National Center 959

Reston, VA 22092
No. of

Copies

W. W. Wood

P.0. Box 3355

Lubbock, TX.79410

D. M. Roy

217 Materials Research Laboratory Pennsylvania State University

University Park, PA 16802

G. McCarthy

217 Materials Research Laboratory Pennsylvania State University University Park, PA 16802

S. Fried

Argonne National Laboratory 9700 South Cass Avenue Argonne, IL 60439

A. M. Friedman

Argonne National Laboratory 9700 South Cass Avenue

Argonne, IL 60439

M. G. Seitz

Argonne National Laboratory

9700 South Cass Avenue

Argonne, IL 60439

M. Steindler

Argonne National Laboratory

9700 South Cass Avenue

Argonne, IL 60439

R. B. Lantz

Intera Environmental Consultants

1201 Dairy Ashord, Suite 200

Houston, TX 77079

G. G. Eichholz

Regent's Professor of Nuclear Engineering

School of Nuclear Engineering

Georgia Institute of Technology

Atlanta, GA 30332 
No. of

Copies

D. Isherwood

Lawrence Livermore Laboratory

MS L-224

P.0. Box 808

Livermore, CA 94550

R. B. Leachman

U.S. Nuclear Regulatory Commission

Division of Fuel Cycle and

Material Safety

Washington, DC 20555

R. F. Kaufman

Evaluation Branch

Office of Radiation Programs

U.S.E.P.A.

P.0. Box 15027

Las Vegas, NV 89114

J. Shade

University of Toledo

Toledo, $\mathrm{OH} 43606$

Dr. H. Walker

Land, Air, and Water Department

225 Hoagland $\mathrm{Hall}$

University of California at Davis

Davis, CA 95616

\section{FORIEGN}

J. Cherry
Department of Earth Sciences
University of Water 100
Waterloo, Ontario
CANADA
Dr. B. Allard
Chalmers University of Technology
Fack
S- 40220 Goteborg 5
SWEDEN

No. of

Copies

K. Brodersen

Waste Management Station

Riso

4000 Roskilde

DENMARK

G. Collard

Department of Chemistry

S.C.K. C.E.N.

Boeretang 200

2400 MOL

Bel Givim

BELGIUM

Dr. D. Grey

Institute of Geologic Sciences

Exhibition Road

$S$. Kensington

London, SW7-2DE

UNITED KINGDOM

R. B. Lyon

Atomic Energy of Canada, Ltd.

3 Lorne Place

Pinawa, Manitoba

CANADA

\section{ONSITE}

\section{ERDA Richland}

0. J. Elgert

R. B. Goranson

D. Squires

M. W. Tiernan

J. A. Fernandez

\section{Battelle-Northwest}

3 H. C. Burkholder

D. B. Cearlock

J. R. Raymond

10 D. Rai

20 R. J. Serne

J. F. Relyea

L. L. Ames 
No. of

Copies

Battelle-Northwest Continued

M. J. Mason

D. A. Myers

A. E. Reisenauer

J. F. Washburn

A. M. Platt

D. J. Bradley

J. A. Stottlemyre

J. W. Bartlett

3 Technical Information

Rockwe 11 Hanford Operations

R. C. Arnett

G. S. Barney

D. J. Brown

R. A. Deju

M. Grutzeck

B. Price

B. Richards

R. C. Routson

3 Rockwe11 Document Control

Boeing Computer

R. W. Nelson

$\underline{\text { UNI }}$

A. L. Cucchiara

Westinghouse

R. B. Hal1 